University of Louisville

ThinkIR: The University of Louisville's Institutional Repository

Electronic Theses and Dissertations

$12-2008$

\title{
The consciousness of damnation : A hermeneutical phenomenology of the fall of the self in Matthew Lewis's "The Monk".
}

Becky Lee Meadows

University of Louisville

Follow this and additional works at: https://ir.library.louisville.edu/etd

\section{Recommended Citation}

Meadows, Becky Lee, "The consciousness of damnation : A hermeneutical phenomenology of the fall of the self in Matthew Lewis's "The Monk"." (2008). Electronic Theses and Dissertations. Paper 956.

https://doi.org/10.18297/etd/956

This Doctoral Dissertation is brought to you for free and open access by ThinkIR: The University of Louisville's Institutional Repository. It has been accepted for inclusion in Electronic Theses and Dissertations by an authorized administrator of ThinkIR: The University of Louisville's Institutional Repository. This title appears here courtesy of the author, who has retained all other copyrights. For more information, please contact thinkir@louisville.edu. 
THE CONSCIOUSNESS OF DAMNATION:

A HERMENEUTICAL PHENOMENOLOGY OF THE FALL OF THE SELF IN MATTHEW LEWIS'S THE MONK

By

Becky Lee Meadows

B.J., University of Missouri-Columbia, 1991

M.A., University of Louisville, 2002

\author{
A Dissertation \\ Submitted to the Faculty of the \\ Graduate School of the University of Louisville \\ in Partial Fulfillment of the Requirements \\ for the Degree of
}

Doctor of Philosophy

$-$

Department of Humanities

University of Louisville

Louisville, $\mathrm{Ky}$.

December 2008 
Copyright 2008 by Becky Lee Meadows

All rights reserved 
THE CONSCIOUSNESS OF DAMNATION:

A HERMENEUTICAL PHENOMENOLOGY OF THE FALL OF THE SELF IN MATTHEW LEWIS'S THE MONK

$$
\text { By }
$$

Becky Lee Meadows

B.J., University of Missouri-Columbia, 1991

M.A., University of Louisville, 2002

A Dissertation Approved on

November 25, 2008

by the following Dissertation Committee:

Dissertation Director 


\section{DEDICATION}

I offer special thanks to the members of my dissertation committee: Dr. Glynis Ridley, professor of English at the University of Louisville, who directed this work; Dr. Annette Allen, professor of Humanities; Dr. Osborne Wiggins, professor of Philosophy; Dr. Robert St. Clair, professor of Communications; and Dr. Karen Hadley, professor of English. I also extend love and heartfelt thanks to those who seemed to understand when I was "dissertating" and unavailable for social calls, especially my husband, Larry Wilson; my son, Michael Wilson; my mother and stepfather, Joyce and William Harmon; my father and stepmother, Larry and Sarah Meadows; my sister, Shelley Moore, and my brothers, Steve Meadows and Billy and Shane Harmon; my grandparents, Mary Meeks and the late John Meeks and the late T.C. and Della Burgess; and my sisters-at-heart, Mikki Tatum, a colleague in the study and teaching of Humanities who counseled me numerous times throughout this work, and Gayle Coulter, my journalism fellow and lifelong friend. I also dedicate this to my cats, Boo-Boo (Shakespeare), Baby Girl, and Happy Cat, for understanding why Mommy wasn't always available to play but always made lap-time. Perhaps it is bold, but in light of the recent death of my older brother, Steve Meadows, who was always interested in my progress on this work, it certainly seems fitting to borrow from Mary Shelley's introduction to the 1831 edition of Frankenstein: "And now, once again, I bid my hideous progeny go forth and prosper. I have an affection for it, for it was the offspring of happy days, when death and grief were but words, which found no true echo in my heart" (Shelley 25). Happy reading! 


\title{
ABSTRACT
}

THE CONSCIOUSNESS OF DAMNATION:

A HERMENEUTICAL PHENOMENOLOGY OF THE FALL OF THE SELF IN MATTHEW LEWIS'S THE MONK

\author{
Becky Lee Meadows
}

November 25, 2008

When Ambrosio in Matthew Lewis's 1796 gothic masterpiece, The Monk, signs a contract relegating his soul to Satan and eternal damnation, he has reached the culmination of 442 pages of mental anguish, of his self wrestling with his conscience to overcome what philosopher Paul Ricoeur terms the "servile will" (The Symbolism of Evil 151). In the novel, Ambrosio, a monk the reader discovers has become the pawn of Satan, hurls himself down a path to damnation in consciousness, a phenomenological path that leads to the damnation of his own self. The purpose of this dissertation is to explore this path through the rich symbols present at each step. Hermeneuticphenomenology-specifically the work of Ricoeur supplemented by works of other phenomenologists such as Edmund Husserl--will provide the foundation for interpretation of the symbols along Ambrosio's phenomenological path to damnation. This will reveal that Ambrosio's self, in effect, damns itself after it progresses down the steps of the path. Ambrosio's conscience acts as the self's internal mirror, striving to present a "true" picture of his self, which resists this truth as it is defined and shaped through false intersubjective constitution with the characters, events, and settings in the 
text, which leads to Ambrosio's existence in what philosopher Jean Paul Sartre terms "bad faith." This work will also trace how Ambrosio's conscience, as it struggles to present "truth" to Ambrosio's self, evolves from Ricoeur's idea of the "unhappy conscience" to the "accused" and "condemned" consciences to what I deem the "damned conscience" as Ambrosio's self moves from Ricoeur's objective pole of sin to the subjective pole. I will expand the steps to damnation from Ricoeur's defilement, sin, and guilt in his The Symbolism of Evil to include original sin and the seven deadly sins at the beginning of the path, and punishment as the final step of the phenomenological path to damnation. In addition, this work posits the symbolism and themes in Lewis's work with other works of gothic literature such as Charlotte Dacre's Zofloya: or the Moor (1808), Mary Shelley's Frankenstein (1818), Edgar Allen Poe's "Ligeia" (1838) and "The Black Cat" (1843), Robert Louis Stevenson's Strange Case of Dr. Jekyll and Mr. Hyde (1886), and Bram Stoker's Dracula (1897). Works of gothic art by Romantic artists such as Henry Fuseli, Francisco de Goya, and William Blake are also analyzed in relation to symbolism and themes in Lewis's work. 
TABLE OF CONTENTS

PAGE

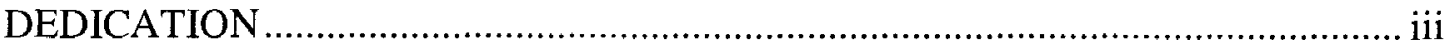

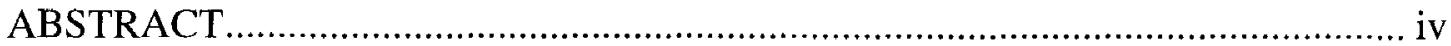

LIST OF FIGURES …............................................................................... vii

CHAPTER I: IN THE BEGINNING:

MATTHEW LEWIS, THE MONK, AND THE CONSCIOUSNESS OF SIN ...........1

CHAPTER II: THE SYMBOLISM OF OBJECTIVE OR ORIGINAL SIN:

CHARACTER-SYMBOLS AS PRIMARY FACTORS OF

INTERSUBJECTIVE CONSTITUTION IN THE MONK.....................................28

CHAPTER III: AT THE MOUTH OF THE PATH TO SUBJECTIVE SIN:

THE SEVEN DEADLY SINS

CHAPTER IV: THE SYMBOLISM OF DEFILEMENT:

THE INITIAL STEP OF THE PHENOMENOLOGICAL PATH

TO DAMNATION IN THE MONK.

CHAPTER V: MOVEMENT FROM THE "UNHAPPY CONSCIENCE"

TO THE "ACCUSED CONSCIENCE": SIN CONSCIOUSNESS AS

PROGRESSION ON THE PHENOMENOLOGICAL PATH

TO DAMNATION IN THE MONK.

CHAPTER VI: SIN-INTERNALIZATION AS GUILT AND PUNISHMENT:

MOVEMENT FROM THE “ACCUSED CONSCIENCE” TO THE

"CONDEMNED” AND "DAMNED" CONSCIENCES AS THE

CULMINATION OF THE PHENOMENOLOGICAL PATH

TO DAMNATION IN THE MONK

REFERENCES

CURRICULUM VITAE. 


\section{LIST OF FIGURES}

FIGURE

PAGE

1. "Satan's First Address to Eve," Henry Fuseli.

2. "French Democrats Surprising Royal Runaways," James Gillray

3. Medieval church wall painting.

4. "The Last Judgment," Cathedral of St. Cecelia

5. "The Nightmare," Henry Fuseli 100

6. Proliferation of Gothic Novels, 1770-1800

7. "Satan, Sin, and Death," William Blake

8. "The Ancient of Days," William Blake

9. "The Sleep of Reason Produces Monsters," Francisco de Goya 160

10. "The Scream," Edward Munch 161

11. "Lucifer and the Pope in Hell," William Blake 161

12. "Satan's First Address to Eve," Henry Fuseli 162 


\section{CHAPTER I: IN THE BEGINNING: MATTHEW LEWIS, THE MONK, AND THE CONSCIOUSNESS OF SIN}

In this lone Cave, in garments lowly, Alike a Foe to noisy folly, And brow-bent gloomy melancholy I wear away My life, and in my office holy Consume the day.

Content and comfort bless me more in This Grot, than e'er I felt before in A Palace, and with thoughts still soaring To God on high, Each night and morn with voice imploring This wish I sigh.

'Let me, Oh! Lord! from life retire, Unknown each guilty worldly fire, Remorseful throb, or loose desire; And when I die, Let me in this belief expire, "To God I fly"!' ("Inscription In An Hermitage," Lewis 51)

It is relatively safe to assume that when 19-year-old Matthew Lewis crafted The Monk in 1796, he had no idea what "hideous progeny" he had created. The text plagued Lewis throughout his life to the point where he earned the nickname "Monk" Lewis, symbolic of criticism he and the text received equating Lewis directly with the ideals in his text. It is also relatively safe to assume Lewis did not realize that when he penned The Monk, he would engage with a rich gothic literary tradition that included such works as Dante's The Divine Comedy (c 1320), Shakespeare's Hamlet (1601), Christopher Marlowe's Dr. Faustus (1604), and Horace Walpole's The Castle of Otranto (1764). 
Lewis undoubtedly had little idea his work would rise to the pinnacle of popularity in an England consumed by its love for gothic romances and enswathed in the language of political turmoil, much less that his work would endure centuries of criticism to become part of the $21^{\text {st }}$ century's love affair with the gothic. Nonetheless, there exist elements in Lewis's primary work that have spoken to humankind across the ages, primarily through his principle character, the fallen monk Ambrosio. Why do The Monk and Ambrosio enwrap our imaginations in the dichotomic play between appeal and repulsion? What does Ambrosio experience in his mental and physical lifeworlds as he catapults himself into damnation in the text, and what can humankind appropriate from his fall?

In Lewis's text, Ambrosio, a self-acclaimed receptor and keeper of holiness, embarks on a journey to damnation of his self in a physical pattern similar to Dante's travels in The Inferno and relegates his soul to Satan in a Dr. Faustian plot device, indicating how Lewis's work engages with medieval protestant ideals, such as the moralfoundational role of the Church, even as it explores chaotic protestant ideals, such as suspicion of the power of religion and government, that emerged and vied for prominence in England prior to and during the French Revolution. However, literary critics have not limited themselves to religious symbolism when analyzing themes in The Monk. Writer Clara Tuite joins the circle of discourse regarding meaning in the gothic when she writes the gothic is not a reaction to the Enlightenment, but instead expresses Enlightenment views, even to the point of providing a place for homosexual performativity through the relationship of Ambrosio to Rosario/Matilda, a demon who first poses as a male to engage Ambrosio's "friendship" (3-4). Ann Campbell points to Lewis's use of satire as the key to meaning in the novel, asserting that satire dissects the social order by revealing 
its arbitrariness; yet, because Lewis offers no solutions to social problems through his satire, he ultimately reinforces social order (2). James Whitlark makes a connection between The Monk and Catholicism and the French Revolution, unlike some of his predecessors who chose either Catholicism or the French Revolution as the primary focus of the novel (4). Marie-Jose Tienhooven, in "All Roads Lead to England: The Monk Constructs the Nation," writes that England lacks a unitary identity, and instead of dedicating itself to difference, it builds unity through the "hierarchical appropriation of a colonized Other"; "The Monk bears out its author's social position and his stated conservatism even as it rejoices in the revolution so dreaded by Burke," she writes (3). In "The Ghost of the Counterfeit-and the Closet--in The Monk," gothic scholar Jerrold Hogle writes how false leads, false images, and false signifiers run rampant throughout the text, in effect paying tribute to "ghost" or counterfeit symbols from much earlier works, such as The Castle of Otranto (2). These ghost symbols are important to this work, which will maintain, in part, that at each step of the phenomenological path to his damnation, Ambrosio's self will be falsely self-constituted with these symbols, people, and events surrounding him. This work participates in previous scholarship regarding The Monk-much like all physical objects participate in Plato's Form of the Good-even as it embarks on a relatively new area of Humanistic studies: the analysis of the very real consciousness of a fictive character existing in a fictive Lifeworld. Unlike previous scholarship investigating The Monk, this work approaches Ambrosio using hermeneuticphenomenology by reading the symbols presented to his consciousness and his reaction-his eventual self-damnation in consciousness, which results in his physical damnation as well - to those archetypal figures. In effect, this work will provide a 
foundational model for understanding the phenomenological path to damnation which may be applied to a range of gothic characters.

The purpose of this work is to explore this path through the rich symbols present at each step and to compare these symbols-or, as Hogle terms them, "ghosts" of symbols-with those that lie along the path of Ambrosio's physical damnation in Lewis's work. Hermeneutic phenomenology, specifically philosopher Paul Ricoeur's The Symbolism of Evil because it addresses applying hermeneutics, the "art of interpretation," with phenomenology, or how we-or, in this case, Ambrosioexperience the multi-vocal symbols we encounter in culture, supplemented by works of other phenomenologists such as Edmund Husserl, will provide the foundation for interpretation of the symbols along Ambrosio's path to self-damnation. Ambrosio progresses down the path to self-damnation with his conscience serving as his internal mirror, an active agent striving to present a "true" picture of his self, which resists this truth as he hurtles down the path. This work will also trace how Ambrosio's conscience, as it struggles to present "truth" to Ambrosio's self, evolves from Ricoeur's idea of the "unhappy conscience" to the "accused" and "condemned" consciences, and eventually to the "damned conscience. We will expand the hermeneutic-phenomenological steps to damnation from Ricoeur's ideas of defilement, sin, and guilt in The Symbolism of Evil to include original sin and the seven deadly sins at the beginning of the path, and punishment as the final step of the path to damnation of Ambrosio's self. To begin, however, and to aid those unfamiliar with Lewis and his masterpiece, we will delve briefly into hermeneutics to establish the "objective mind" of British culture when The Monk was born, which includes the philosophical concept of "historical consciousness." 
Together, these shaped the reception of The Monk in culture, as we shall see when we later examine the reception of the text alongside political and cultural events of its day.

This idea of what art and literature are in their basic forms is part of our historical consciousness. Philosopher Hans-Georg Gadamer explains the idea of historical consciousness, and how it is tied in with the concept of tradition:

Research in the human sciences cannot regard itself as in an absolute antithesis to the way in which we, as historical beings, relate to the past. At any rate, our usual relationship to the past is not characterized by distancing and freeing ourselves from tradition. Rather, we are always situated within traditions, and this is no objectifying process-i.e., we do not conceive of what tradition says as something other, something alien. It is always part of us, a model or exemplar, a kind of cognizance that our latter historical judgment would hardly regard as a kind of knowledge but as the most ingenuous affinity with tradition. . . Our historical consciousness is always filled with a variety of voices in which the echo of the past is heard. Only in the multifariousness of such voices does it exist: this constitutes the nature of the tradition in which we want to share and have a part. $(282-4)$

Tradition is part of our life-relation with other humans, which comprises our historical consciousness. Along these lines, Lewis's historical consciousness of literature-including gothic literature such as The Castle of Otranto (1762)-would have shaped his work, if not necessarily the structures of Ambrosio's consciousness. Ricoeur explains:

Every human science-. . . every modality of the knowledge of man which implies an historical relation-presupposes a primordial capacity to transpose oneself into the mental life of others. In the human order, man knows man; however alien another man may be to us, he is not alien in the sense of an unknowable physical thing. (The Symbolism of Evil 49)

In addition, our historical consciousness of literature and art, coupled with the

"objective mind" of our culture, dictates how our culture will respond to works of art.

Philosopher Wilhelm Dilthey explains:

By this (objective mind) I mean the manifold forms in which what individuals hold in common have objectified themselves in the world of the 
senses. In this objective mind the past is a permanently enduring present for us. Its realm extends from the style of life and the forms of social intercourse to the system of purposes which society has created for itself and to custom, law, state, religion, art, science, and philosophy. For even the work of genius represents ideas, feelings and ideals commonly held in an age and environment. From this world of objective mind the self receives sustenance from earliest childhood. It is the medium in which the understanding of other people and their expressions take place. (221)

The objective mind of our culture sets the cultural "mood" for art, as well as other creative endeavors. For example, the objective mind of the culture in England in the late 1700 s was not good toward the novel - it was commonplace to downgrade the novel as a "Romance" that threatened the morality of the culture. Gothic literature was especially suspect during this time; Lewis, in fact, was prosecuted in British courts and forced to publish a censored version of his work. In contrast, our current culture embraces the horror genre-in fact, it is one of the best-selling genres for movies and books, as evidenced by the success of author Stephen King in popular culture. This illustrates how objective mind operates; a particular opinion remains in place until society begins to question it, after which that opinion may be changed. However, what has changed is only one particular aspect of the objective mind. Rarely does an entire objective mind completely disappear, but instead continually evolves with time. Next, we will explore British culture's reception of The Monk and the conditions in England at the time it was born from Lewis's consciousness- - both products of the Objective Mind of Lewis's culture.

Imagining the King's Death: The Political Conflict of Language in England in the 1790s I thought ten thousand swords must have leaped from their scabbards to avenge even a look that threatened her with insult. But the age of chivalry is gone. That of sophists, 
oeconomists, and calculators, has succeeded, and the glory of Europe is extinguished forever. (Burke 16)

Literary critics have zealously pointed to the French Revolution as a primary factor influencing gothic texts, especially those written during the turbulent 1790s. At this point, the revolutionaries had imprisoned the French royal family, and Robespierre had led the Jacobins to power. The impact of the revolution on British culture is illustrated in the tensions and dichotomic struggle between conservative and liberal writers/philosophers in England. One of the most influential texts of this time, Edmund Burke's Reflections on the Revolution in France, expresses the conservative view eloquently:

Every thing seems out of nature in this strange chaos of levity and ferocity, and of all sorts of crimes jumbled together with all sorts of follies. In viewing this monstrous tragic-comic scene, the most opposite passions necessarily succeed, and sometimes mix with each other in the mind; alternate contempt and indignation, alternate laughter and tears; alternate scorn and horror. ... All the pleasing illusions, which made power gentle, and obedience liberal, which harmonized the different shades of life, and which, by a bland assimilation, incorporated into politics the sentiments which beautify and soften private society, are to be dissolved by this new conquering empire of light and reason. All the decent drapery of life is to be rudely torn off. All the superadded ideas, furnished from the wardrobe of moral imagination, which the heart owns, and the understanding ratifies, as necessary to cover the defects of our naked shivering nature, and to raise it to dignity in our own estimation, are to be exploded as ridiculous, absurd, and antiquated fashion. (16)

Note the equating of theatre, an act of imagination, and the use of the word imagination; in the political struggle between liberal and conservative, each accused the other of too much imagination to the point where the meaning of the word imagination became suspect and even manipulated within the British legal system, writes John Barrell in Imagining The King's Death: "Ministers were regularly warned not to fall prey to imaginary fears; extravagant arguments in parliament were reprobated as the inventions 
of a too active imagination," he writes (8). Critics, such as Mary Wollstonecraft and William Godwin, warned that Burke's language was dangerously figurative and owed "more to the imagination than to strict historical truth" (9). Burke's work suggested the art of government was perhaps best understood through imagination, not reason; "Still, more provocatively, the imagination, here and there in the text, was attributed with a positive and active role in the processes of social affiliation and the formation of political identities, a role which Burke's opponents could understand only as proposing that government was a mode of deception," Barrell writes (9). In essence, Burke had abandoned the path of reason in favor of imagination that can lead us into error. The imagination became associated with irrational behavior in some circles, which could well be responsible, at least in part, for the high-culture reception of romances such as The Monk.

However, the word "imagination" appropriated more sophisticated and potentially deadly connotations in the British legal world of the 1790 s. Barrell writes, "When in 1792 the alarm started by Burke began to develop into the fear that Britain too was in danger of revolution, the relationship between alarmism and the imagination was used to describe those like John Reeves, founder of the Loyalist Associations, and Archibald Macdonald, the Attorney-General, who together presided over the early phase of Pitt's 'White Terror.' 'Saucer-eyed phantoms of Sedition,' wrote Vicesimus Knox of this period, "began to flit through disturbed imaginations" (17). In actions reminiscent of the McCarthy-induced "Red Scare," some political philosophers were put on trial for their writings in regard to the English legal code specifying that "when a man doth compass or imagine the death of our lord the king," it was treason. Some referred to imagination as a 
purpose or design of the mind or will (Barrell 30). The meaning comes, in part, from the King James version of The Holy Bible, Barrell explains:

Indeed, the use of "imagine" and "imagination" in the Bible, which might have been expected to lend the legal meaning of the words a degree of stability, probably contributed to their destabilization, by supplying lawyers with such ready-made oratorical phrases as "wicked imaginations" and "evil imaginations," whose meaning in the Bible was imperfectly understood. ... The Crown lawyers in trials for high treason in the 1790s frequently use such phrases to attribute a dark and Gothic cast of mind to those they are prosecuting. They speak of "wicked imaginations" in the heart of the traitor, the "desperate imagination" of the supposed revolutionary, and may well have been taken to be accusing the defendants not of intending the king's death, but merely of imagining it in the weak sense, by an association of ideas, however involuntary. (33)

Barrell mentions writers such as Jeremy Bentham in 1795 "discussed and deplored at length" the idea of imagining the king's death as treason. However, the instability of the political climate, coupled with the anti-romantic association of the word "imagination," created a perfect atmosphere of contempt for works such as The Monk. Ambrosio's imagination of Matilda after he first sees parts of her body exposed from her cloak incite his sexual fantasies; in fact, it is his sexual fantasy for Antonia, infused through his real or imaginary pictorial of her, unclothed, in the mirror Matilda holds for him, that first solidifies his plan to enjoy her sexually. This language of "imagination" and its multiple meanings are also exhibited in The Monk itself through the discourse Lewis chooses to express Ambrosio's physical and spiritual damnation. As Ambrosio is lusting after the portrait of the Virgin Mary in his room at the abbey, he castigates himself: "Fool that I am! Whither do I suffer my admiration of this picture to hurry me? Away, impure ideas!" (Lewis 41). In fact, one of the initial steps of Ambrosio's phenomenological path to damnation begins when he engages in an "as-if" experience as he contemplates life outside the abbey. This behavior, exhibited from a character that should have represented 
the highest form of moral righteousness in a culture, incited rounds of written discourses of abuse for Lewis and his work, and yet illustrated the dichotomic play between highand low-culture as the publishing house could not print enough copies of the first version of The Monk to supply the demand for it. With these ideas in mind, we move to a more detailed examination of the cultural reception of Lewis's masterpiece

Cultural Reception of The Monk

I was going to say that you cannot employ your time worse than in making verses. An Author, whether good or bad, or between both, is an Animal whom everybody is privileged to attack; For though All are not able to write books, all conceive themselves able to judge them. A bad composition carries with it its own punishment, contempt and ridicule. A good one excites envy, and entails upon its Author a thousand mortifications. He finds himself assailed by partial and ill-humoured Criticism: One Man finds fault with the plan, Another with the style, a Third with the precept, which it strives to inculcate; and they who cannot succeed in finding fault with the Book, employ themselves in stigmatizing its Author. They maliciously rake out from obscurity every little circumstance which may throw ridicule upon his private character or conduct, and aim at wounding the Man, since They cannot hurt the Writer. In short, to enter the lists of literature is wilfully to expose yourself to the arrows of neglect, ridicule, envy, and disappointment. (The Marquis de la Cisternas, Lewis 198-9)

Interestingly, first reviews of The Monk were positive, according to Lewis biographer Louis F. Peck: "The book sold well from the start, and a second edition was published in October 1796. Reassured by the reviews, Lewis affixed his name to the title page of this new edition, and, having recently taken his seat in the House of Commons, added his new title M.P., a stroke of vanity for which he was to pay dearly" (24). Four months after publication of The Monk in 1796, the Monthly Mirror gave it a stamp of approval: "We really do not remember to have read a more interesting production," the critic wrote (24). However, a warning rumble of the approaching storm of unpleasant reviews accusing Lewis of immorality and calling for his "indictment under common 
law" began with a small review in European Magazine in February 1797 (24-6). The storm came to a boil when Samuel Taylor Coleridge's review of The Monk was published that same month: "The sufferings which he [Lewis] describes are so frightful and intolerable, that we break with abruptness from the delusion, and indignantly suspect the man of a species of brutality, who could find a pleasure in wantonly imagining them; and the abominations which he pourtrays with no hurrying pencil, are such as the observation of character by no means demanded, such as 'no observation of character can justify, because no good man would willingly suffer them to pass, however transiently, through his own mind" (Coleridge). Note here the direct association of "imagination" with Lewis's supposed ideals in relation to our previous discussion of the political climate and the controversy over the meaning of the word "imagination."

However, Coleridge does pay tribute to Lewis's budding genius when he refers to the character of Matilda as "the author's masterpiece. It is, indeed, exquisitely imagined, and exquisitely supported" (Coleridge). Coleridge, of course, as a member of British "high culture," expresses the views of the elite in England, the ideas of the educated wealthy class, or, as Marx would term it, the "bourgeoisie." Coleridge was quick to add that The Monk's poisonous nature is "a fault for which no literary excellence can atone," and it is a romance "which if a parent saw in the hands of a son or daughter, he might reasonably turn pale" (Peck 25). Coleridge was far from alone in his condemnation of Lewis's lifework: Thomas James Mathias in July 1797 wrote that The Monk's passage regarding the Bible was indictable under common law. "A legislator in our parliament, a member of the House of Commons of Great Britain, an elected guardian and defender of the laws, the religion, and the good manners of the country, has neither 
scrupled nor blushed to depict, and to publish to the world, the arts of lewd and systematic seduction, and to thrust upon the nation the most unqualified blasphemy against the very code and volume of our religion," Mathias wrote (Peck 26) in a tirade similar to those expressed during the 1794 British treason trials. Mathias's work contains important clues to high-culture's reaction to The Monk; Mathias had also written that "Literature, well or ill conducted, is the great engine by which... all civilized States must ultimately be supported or overthrown" (26), again illustrating the culture's Objective Mind association of the imagination with the political.

Mathias and Coleridge, and Lewis, were writing in an atmosphere charged with "political and religious conservatism," and for a public frightened by the French and American Revolutions. As Peck writes, "revulsion from eighteenth-century coarseness" was in progress; "societies for the promotion of morality were springing up; censorship and expurgation were being carried to a point that today seems prudish. Public opinion and the press were particularly severe on atheism and religious defection" (27). However, Peck points out that attacks on the Bible were common; Paine's Age of Reason, to Peck, made Lewis's work seem harmless and naive (27). For Coleridge, Mathias, and other members of the British upper class, however, events of this time were crucial moments in British history. "To many it was, as Mathias put it, 'an awful and a pressing hour,' and we can believe that flippancy toward the Bible may well have heralded for him the collapse of Christian civilization," Peck writes. In such an atmosphere, The Monk rapidly became a subject of public controversy (27). The Monk took what appeared to be cornerstones of British culture--religion, honor, even good manners - and placed them in opposition with themselves in a mix of cultural contradictions. To further infuse the 
displeasure of the upper classes, members of low-culture were consuming Lewis's book with added fervor, especially after negative reviews of it were published.

The book reached its publishing height by 1800 , when five London and two Dublin editions, in addition to pirated versions, were needed to fill the market. Even so, many potential readers were unable to obtain copies of the text because it sold as fast as it was printed. Britain Anna Seward had not been able to obtain a copy by December 27, 1796, about six months after the text was first reviewed: "Of the Monk, I have been long in pursuit through the mazes of hireling circulation. Henry White, my literary huntsman, has been foiled in the track" (29). Peck writes, "Frances Lady Shelley years later recalled how when she was a girl her mother had imprudently forbidden her The Monk, 'at that time the subject of conversation in all societies,' and how one night, having received a copy from a misguided friend, she struggled long by candlelight before conquering the temptation to read it" (29). Despite its publishing success, Matthew "Monk" Lewis did publish a censored fourth edition of the text because of political pressure (34). However, it was deemed a dismal failure; the public preferred the uncensored first edition.

The Monk was also made into several dramas, all censored versions of the original text. One version, produced at Drury Lane on Dec. 29, 1798, was abandoned after six nights (31). Apparently Lewis attended the show, and he wrote, "it was no sooner found out that Miranda [Matilda] was a virtuous woman, instead of a demon, that many in the pit and galleries evinced dissatisfaction" (31). Eleven-year-old Mary Russell Mitford was in the audience one night, and wrote more than 40 years later in a letter to Elizabeth Barrett how, during the show, Mrs. Siddons "knocked the head of the huge wax doll she carried so violently against the wooden framework that the unlucky figure broke 
its neck with the force of the blow, and the waxen head came rolling along the front of the stage, to the accompaniment of laughter unrivaled since the production of 'Tom Thumb" (32).

Like his text, Lewis himself did not fit perfectly into the high-culture mold. Although he served in the House of Commons from 1796 to 1802 , his career in politics meant little to him (Peck 43). However, his social life did not lack glitter; he was accepted into many upper-class social circles and even had royalty among his acquaintances (43). In 1803, the Duke of Clarence requested his presence at dinner since he was "a man of Romance and Sentiment," and Lewis commented, "I am quite glad to find that Romance and Sentiment can, once in his life, get a man a dinner. I'm sure I've lost many things by them, and never got anything before" (44). Sir Walter Scott commented that Lewis was "fonder of great people than he ought to have been, either as a man of talent or a man of fortune. He had always dukes and duchesses in his mouth, and was particularly fond of any one who had a title. You would have sworn he would have been a parvenu of yesterday, yet he had been all his life in good society" (45). However, Peck writes that Lewis could easily bore his friends, and quotes a description of Lewis saying he was "disliked by all man and womankind, but thrusting himself into all the best society and frequently at Kensington, a hateful little animal, with just genius enough to complete his disagreeableness, constantly talking about himself, his heart, his feelings, etc." (46). Such descriptions paint a picture of "Monk" Lewis as a man caught between high- and low-culture, someone who aspired to high-culture and found himself the center of the binary opposition of high-culture ideals and popular-culture taste, especially through his character, Ambrosio, the fallen monk himself a symbol of 
Ricoeur's idea of the servile will, or humankind ensnared in a physical body susceptible to temptations of physical pleasures with its accompanying mental captivity to the God of the Hebrew covenant. We begin our analysis of Ambrosio's phenomenological path to damnation with an examination of the basic aspects of Ricoeur's philosophy, ideas we will examine in more detail as we progress down the path.

"Evil," Hermeneutics, and Phenomenology: "Symbols Give Rise to Thought"

Understanding of symbols can play a part in the movement towards the point of departure; for, if the beginning is to be reached, it is first necessary for thought to inhabit the fullness of language.

(Ricoeur, The Symbolism of Evil 348)

A hermeneutic-phenomenological examination of Ambrosio's consciousness is necessary to determine his specific steps on his phenomenological path to damnation, as this work establishes, and the primary work published to date detailing a hermeneuticalphenomenological approach to the experience of evil is Ricoeur's The Symbolism of Evil. We approach the use of Ricoeur's work as an "ideal type" from which to spring into our own creation of the phenomenological path to damnation for a fictive consciousness. While we will expand upon Ricoeur's ideas, such as separating his idea of the "accused and condemned conscience" into separate parts (the "accused" and the "condemned" consciences) and add a step to his hermeneutic-phenomenology of evil ("punishment" for the "damned" conscience), Ricoeur's idea of the path to damnation-defilement, sin, and guilt-will form the beginning steps of our exploration. To begin, an examination of Ricoeur's ideas of "evil," along with his philosophy of applying phenomenology and hermeneutics to the interpretation of the symbols of evil, should enhance the true understanding of the "self," an entity that we discover over time (Ricoeur, "Forward," 
xvii). Here, Ricoeur applies the notion of "self" to people; for this work, we will apply it to a literary character. In addition, Ricoeur's hermeneutic phenomenology should enlighten interpretations of symbols of evil in The Monk, leading to a greater understanding of Ambrosio's self through the examination of the text; "Hence to study the symbolism of evil through confessions of fault is to study basic epistemology and ontology that will illuminate the nature and interaction of self, will, and other," Robert Detweiler writes (58). This, in effect, is the heart of the foundational model for this work.

For Ricoeur, the conception of evil in the religious consciousness is based on a hierarchal triad: defilement, sin, and guilt, with defilement at the most basic level of understanding of his triad. Ricoeur writes:

In truth, defilement was never literally a stain; impurity was never literally filthiness, dirtiness. . . . The representation of defilement dwells in the half-light of a quasi-physical infection that points toward a quasi-moral unworthiness. This ambiguity is not expressed conceptually but is experienced intentionally in the very quality of the half-physical, half-ethical fear that clings to the representation of the impure. (35)

In $18^{\text {th }}$ and $19^{\text {th }}$ century literature, defilement is certainly recognizable, especially in male gothic. As we shall see, Ambrosio mourns his defilement and wonders how he can ever clear its "stain" from himself, After Ambrosio has raped Antonia, she rises to leave, and when he moves toward her, she says, "What would you more? Is not my ruin completed? Am I not undone, undone forever? Is not your cruelty contented, or have I more to suffer?" (Lewis 384) We will examine the role of defilement in other gothic texts, including "The Rhyme of the Ancient Mariner" (1798), Frankenstein (1818), Strange Case of Dr. Jekyll and Mr. Hyde (1886), and Dracula (1897) in Chapter 4 this work.

However, only in the progress of conscience, as it advances beyond defilement and yet retains its notion of it, is the meaning of defilement recognized. This leads to 
Ricoeur's philosophy of "sin." Sin is the conscience recognizing that the bond between man and God, the concept of the Hebrew covenant, has been broken (48). The Hebrew prophets point to different types of "evil" that are sin: iniquity, which comes from a wicked heart; pride, arrogance, false greatness; and adultery (57). Such sins are acknowledged at times by the absence of God which, according to Ricoeur, is an "insecurity and an anguish worse than suffering" (57). God transforms into the "Wholly Other," a being set in opposition to humankind, per Ricoeur. For this work, we shall depart from Ricoeur when we establish how Ambrosio thrusts God aside as the "Mythological Other" as opposed to the "Wholly Other"; the "Mythological Other" is a being that exists only in the imagination as opposed to existing in reality and the imagination.

After an initial defilement and the recognition of $\sin$, Ricoeur turns to the ensuing guilt humankind may feel. In The Monk, we see Ambrosio experience guilt after he has raped Antonia:

As his gloomy rage abated, in proportion did his compassion augment for Antonia. He stopped, and would have spoken to her words of comfort; but $\mathrm{He}$ knew not from whence to draw them, and remained gazing upon her with mournful wildness. Her situation seemed so hopeless, so woe-begone, so as to baffle mortal power to relieve her. What could He do for her? Her peace of mind was lost, her honor irreparably ruined. ... He was conscious that were She to appear in the world again, his guilt would be revealed, and his punishment inevitable. To one so laden with crimes, Death came armed with double Terrors. (Lewis 386-7)

Here, Ambrosio's guilt is spurred by his anticipation of punishment, which, for this work, will be explored through the dichotomy of God as Salvation and God as Punishment. "Guiltiness is never anything else than the anticipated chastisement itself, internalized and already weighing upon consciousness; and as dread is from the beginning the way of 
internalization of defilement itself, in spite of the radical externality of the evil, guilt is a moment contemporaneous with defilement itself," Ricoeur writes (101).

Ricoeur's philosophy of evil culminates in his concept of the "servile will," the human will that is slave to its own passions (Detweiler 59). The servile will, for Ricoeur, is a captive free will. "Thus the captivity of the body and even the captivity of the soul in the body are the symbol of the evil that the soul inflicts on itself, the symbol of the affection of freedom by itself; the "loosing" of the soul assures us retrospectively that its "bonds" were the bonds of desire, active-passive fascination, autocaptivity; "to be lost" means the same thing," Ricoeur writes (154).

How can we come to a better understanding of the symbols and metaphors of evil that proliferate The Monk? Ricoeur maintains that a combination of phenomenology and hermeneutics is necessary to fully understand the significations of evil. For example, Ricoeur examines the cultural values behind defilement, sin, and guilt in The Symbolism of Evil: defilement is not a physical stain, but is "symbolic" stain; "sin" is the recognition of the breaking of the covenant between humankind and what it considers sacred, often God; and guilt is the "anticipated chastisement itself, internalized and already weighing upon consciousness" (Evil 101). The consciousness of fault is not fully experienced until it is expressed through the language of confession, Ricoeur writes:

It is this emotional note that gives rise to objectification in discourse; the confession expresses, pushes to the outside, the emotion which without it would be shut up in itself, as an impression in the soul. Language is the light of the emotions. Through confession the consciousness of fault is brought into the light of speech; through confession man remains speech, even in the experience of his own absurdity, suffering, and anguish. (Evil 7)

Then, for Ricoeur, the problem becomes the relationship between life "as the bearer of meaning" and the mind "as capable of linking meanings into a coherent series" 
("Existence" 5). The bridge between these two are symbols and metaphors in language, both of which bear meaning of lived experiences and point to something other than themselves, other meanings that are layered within. This idea is already a hermeneutics, Ricoeur writes, "for the most primitive and least mythical language is already a symbolic language: defilement is spoken of under the symbol of stain or blemish, sin under the symbol of missing the mark, of a tortuous road, of trespass, etc. In short, the preferred language of fault appears to be indirect and based on imagery" (Evil 9). Confession manifests itself in language, and that language of fault is essentially symbolic.

Symbols are "primitive metaphors" in which evil is understood to be "like" a defilement, a broken relationship, or a self-induced punishment (Idhe 95). Symbols are the base of language; above them are myths, which elaborate and expand the possible meanings of symbols. There are tensions between symbols and myths, and through these a broad "logic" of myths begins to emerge. When we apply phenomenology and hermeneutics to the understanding of symbols and myths, a "first" and "second" order of indirectness for the understanding of experience emerges (Idhe 96). The first concerns the relationship of experience to expression, and the second the possibility of interpreting expressions through hermeneutics. In addition, Ricoeur writes:

A purely semantic elucidation remains suspended until one shows that the understanding of multivocal or symbolic expressions is a moment of selfunderstanding; the semantic approach thus entails a reflective approach. But the subject that interprets himself while interpreting signs is no longer the cogito: rather, he is a being who discovers, by the exegesis of his own life, that he is placed in being before he places and possesses himself. In this way, hermeneutics would discover a manner of existing which would remain from start to finish a being-interpreted. Reflection alone, by suppressing itself as reflection, can reach the ontological roots of understanding. Yet this is what always happens in language, and it occurs through the movement of reflection. ("Existence" 11) 
"Symbols give rise to thought," Ricoeur writes (Evil 19). This, in turn, gives rise to selfunderstanding. When applied to gothic literature, or any literary text in a sense, the interpretation of symbols and metaphors, which is hermeneutics, leads to fuller selfinterpretation. However, language is the expression of experience, and the description of experience is the heart of phenomenology. Thus, the experience of fault or evil leads to confession-the written or verbal expression of that experience, which is usually expressed in symbols and metaphors—and these, according to Ricoeur, must be interpreted hermeneutically.

It is important to note here that this work embarks into new territory by applying Ricoeur's central ideas to a fictive consciousness. Ricoeur traces the meaning and experience of religious symbols from the ancient Greeks and examines how they came to be interpreted as we do today; in other words, Ricoeur applies his ideas to the consciousnesses of the living. Ambrosio is a fictive consciousness, and this presents some difficulties, such as the incompleteness of a fictive consciousness. To buttress this, we will apply Weber's idea of the "ideal type" to Ambrosio by equating his consciousness with the "ideal type religious consciousness." In addition, Ricoeur maintains confession is essential; however, at no point in Lewis's text does Ambrosio confess. This will be a prime contributory factor to the monk's self-damnation.

Consciousness in the Lifeworld and the Fictive World

"Fear not, Ambrosio! Take confidence in the strength of your virtue. Enter boldly into a world, to whose failings you are superior; Reflect that you are now exempted from Humanity's defects, and defy all the arts of the Spirits of Darkness. They shall know you for what you are!" (Ambrosio, Lewis 41) 
" 'Who,' thought He; 'Who but myself has passed the ordeal of Youth, yet sees no single stain upon his conscience?" Ambrosio boasts in our first access to his thoughts in The Monk (40). Yet, immediately after telling himself how gloriously guilt-free he is, Ambrosio turns to an image of the Virgin Mary on his wall and exclaims, "Oh! If such Creature existed, and existed but for me! Were I permitted to twine round my fingers those golden ringlets, and press with my lips the treasures of that snowy bosom!"' (41). How is it that Ambrosio, a monk raised in all the fervor of the Catholic tradition, can

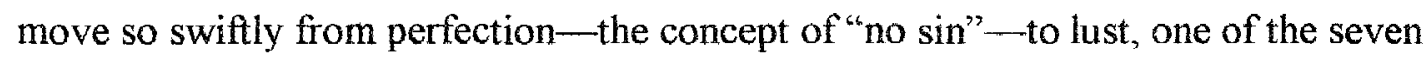
deadly sins? How can one well-versed in religious morality be so seemingly ignorant of-or just blatantly ignore--his own sin? The answer to this question lies in Ambrosio's consciousness of sin and the role of the conscience in his consciousness and appropriation of symbols of $\sin$. Lewis has given us avenue to explore Ambrosio's thoughts and those of the characters, events, and environments in the text that surround Ambrosio and are part of the intersubjective constitution of his self. We may explore Ambrosio's "Lifeworld," which for readers is a "fictive world," through hermeneutic phenomenology - an analysis of how Ambrosio's self is shaped and eventually selfdamned through the symbols around him. However, it is important to examine how phenomenological methodology in the Lifeworld may be applied to the fictive world before we can layer additional meaning through symbols to our analysis; for example, as we shall see, consciousness in the fictive world is limited by the author of a fictive text. For this work, we borrow the concept of intersubjective constitution in the Lifeworld from Edmund Husserl, the "father of phenomenology," because it is through his false 
intersubjective constitution of the people, places, and events around him that Ambrosio vaults himself down the phenomenological path to damnation.

According to Husserl, my "self" is defined through intersubjective constitution with elements of my Lifeworld, according to Husserl. The symbols that surround me are intended by my consciousness and become part of my interpretation of my self and the Lifeworld. I project my idea of self toward other objects in the world and reaffirm my identity through the multiple channels of communication between my self and other elements in the Lifeworld. This is where hermeneutic phenomenology comes into play: interpretation of the symbols presented to me in the Lifeworld aids in my determination of how my "self" has evolved and how I define myself. The idea of intersubjective constitution will be integral to an analysis of Ambrosio's consciousness of self in The Monk.

In the fictive world, the "self" of a character is limited by parameters set by its creator, the author of the fictive text. For example, in The Monk, we have access only to what Lewis has given us in the fictive world he created. Ambrosio's thoughts, or fictivephysical manifestations of his consciousness, are presented at times by Ambrosio himself, such as when he first sees Antonia: "What would be too dear a price for this lovely Girl's affections?" he exclaims to himself. "What would I refuse to sacrifice, could I be released from my vows, and permitted to declare my love in the sight of earth and heaven? ... Yes; If there is perfect bliss on earth, 'tis his lot alone, who becomes that Angel's Husband" (Lewis 243). At other times, Ambrosio's thoughts are "given" by the omniscient narrator: "But Antonia's Empire over him was already too much decided to permit his making a long resistance to the idea which struck him. He resolved to be the 
Confessor himself' (244). Ambrosio's self is also intersubjectively constituted with elements of the fictive world around him. For example, when The Monk opens, a crowd has gathered, Ambrosio thinks, to listen to his sermon; however, Lewis gives us another take on this situation:

The Women came to show themselves, the Men to see the Woman: Some were attracted by curiosity to hear an Orator so celebrated; Some came because they had no better means of employing their time till the play began; Some, from being assured that it would be impossible to find places in the Church; and one half of Madrid was brought thither by expecting to meet the other half. The only persons truly anxious to hear the Preacher were a few antiquated devotees, and half a dozen rival Orators, determined to find fault with and ridicule the discourse. (Lewis 7)

Here Lewis gives a clear example of how Ambrosio's self becomes falsely selfconstituted with people and events that surround him. When he returns to his chambers, Ambrosio's imagination presents him with "splendid visions of aggrandizement," and Lewis presents readers with their first clue to Ambrosio's true "self" as the monk gives way to the deadly sin of Pride (39). Ambrosio begins his journey down the path to damnation when his self starts to become falsely self-constituted. To understand this, we must examine the role of conscience in the consciousness of damnation because Ambrosio's conscience acts as a pro-active agent that struggles to present a true picture of his "self" even as Ambrosio denies or ignores this picture.

The Role of the Conscience in the Path to Self-Damnation: The Progress from the "Guilty Conscience" to the "Accused" and "Condemned" Consciences to the "Damned Conscience"

The better to cloak his transgression, He redoubled his pretensions to the semblance of virtue, and never appeared more devoted to Heaven as since He had broken through his engagements. Thus did He unconsciously add Hypocrisy to perjury and incontinence; $\mathrm{He}$ 
had fallen into the latter errors from yielding to seduction almost irresistible; But he was now guilty of a voluntary fault by endeavouring to conceal those, into which Another had betrayed him. (Lewis 226)

What is the conscience and its relationship to the self? According to philosopher John Henry Newman (1801-1890), conscience is "a sense of responsibility and duty that points toward something beyond the realm of people, toward a Supreme Governor or Judge whose dictates we are ashamed or fear to violate and whose approval we seek" (Moore 416). Newman's ideas fit perfectly with Ricoeur's, establishing the relationship of conscience to God. For Ricoeur, "Hell" begins with the "accused and condemned conscience," but one must begin with the guilty conscience, or one that is shut in because it is isolated: it breaks the communion of sinners. It separates itself as it takes the whole weight of evil upon itself (The Symbolism of Evil 146). It is a slave and is conscious of its own enslavement; it is a conscience without "promise" in what Kierkegaard terms "despair" (146); as we shall see in Chapter 6 of this work, the idea of despair as Kierkegaard envisioned it is integral to Ambrosio's self-damnation. The conscience becomes a despairing and desperate will to shut oneself up in the circle of interdiction and desire. We see this and Ricoeur's concept of the "servile will" evidenced at the end of The Monk when Ambrosio is awaiting his fate at the hands of the Inquisition after his rape and murder of Antonia and the murder of Antonia's mother ${ }^{2}$ :

While Reason forced him to acknowledge a God's existence, Conscience made him doubt the infinity of his goodness. He disbelieved, that a Sinner like him could find mercy. He had not been deceived into error: Ignorance could furnish him with no excuse. He had seen vice in her true colours; Before $\mathrm{He}$ committed his crimes, He had computed every scruple of their weight; and yet he had committed them. "Pardon?" He would cry in an access of Phrenzy; "Oh! There can be none for me!" Persuaded of this, instead of humbling himself in penitence, of deploring his guilt, and employing his few remaining hours in deprecating Heaven's wrath, He abandoned himself to the transports of desperate rage; He sorrowed for the punishments of his crimes, not their commission; and 
exhaled his bosom's anguish in idle sighs, in vain lamentations, in blasphemy and despair. (Lewis 426)

Here, we see Ambrosio's conscience acting as a pro-active agent struggling to present to his "self" a true picture of his self, even as he denies or ignores its warnings.

The conscience, in this instance, is not conjoined with the self, but is rather separate from it, even as it acts as a mirror for the self, as we see when Ambrosio hears Agnes groan in the sepulcher as he awaits Matilda's preparation for their first visit with Satan:

Yet deeper groans followed these words. They died away gradually, and universal silence again prevailed.

"What can this mean?" thought the bewildered Monk.

At that moment an idea which flashed into his mind, almost petrified him with horror. He started, and shuddered at himself.

"Should it be possible!" He groaned involuntarily; "Should it but be possible, Oh! What a Monster am I!"

He wished to resolve his doubts, and to repair his fault, if it were not too late already; But these generous and compassionate sentiments were soon put to flight by the return of Matilda. He forgot the groaning Sufferer, and remembered nothing but the danger and embarrassment of his own situation. (Lewis 274)

Lewis gives us access to Ambrosio's conscience, acting as a mirror struggling to present a "true" picture of his self to himself; however, Ambrosio ignores this picture in light of his own possible "danger and embarrassment." As we shall see, this is but one of many similar situations throughout the text.

Because this analysis is of a fictive world, the only evidence we have is that which Lewis gives us, in language and in symbols, metaphors, images, and characters he creates for us in language. Ambrosio's conscience is evidenced to us through his thoughts and those of the narrator and, at times, through his actions, or possible physical representations of his conscience. Following the journey of Ambrosio's conscience from the "guilty conscience" to the "accused" and "condemned" consciences to the "damned conscience" by interpreting the symbols and imagery, both linguistic and pictorial, in the 
text, will enlighten the path Ambrosio follows to the fall and damnation of his self.

Following Ricoeur's guidelines, we will explore "a creative interpretation of meaning, faithful to the impulsion, to the gift of meaning from the symbol, and faithful also to the philosopher's oath to seek understanding. This is the road, requiring patience and rigor on our part, which is indicated by the aphorism inscribed at the head of this conclusion: 'The . symbol gives rise to thought." (The Symbolism of Evil 348). We begin at Ricoeur's "objective pole" with an analysis of the symbolism that points Ambrosio to the path to self-damnation: the concept of original sin. 


\section{Endnotes}

1 Because this work employs hermeneutic-phenomenology as opposed to straight hermeneutics, it is not necessary to delve deeply into theories of hermeneutics by major practitioners of this discipline. However, it is worth mentioning that Ricoeur's ideas must be grounded at least partially on the work of the hermeneuticians who came before him, such as Rudolf Bultmann, who maintained the questioner's life experiences and their relation to the symbols in the text must be analyzed; Hans Georg Gadamer, who maintains we must acknowledge our own "prejudices" as we proceed with the analysis of symbols, texts, and art; and Friedrich Schleiermacher, the "father" of hermeneutics. Also, for Ricoeur, confession must be expressed audibly; otherwise, the guilt is confined within the soul. Ambrosio never confesses his sins aloud, but he does express his guilt in his thoughts in Lewis's text.

2 The Spanish Inquisition began in 1481 and ended around the time of the Enlightenment. I set the time period of The Monk as between 1500 and 1660, a date sometimes surmised as the end of the Inquisition, because at the end of the novel, Ambrosio is terrified of the Inquisition, which indicates it was at its peak. Obviously it took years for the Inquisition to reach its peak. 


\section{CHAPTER II: THE SYMBOLISM OF OBJECTIVE OR ORIGINAL SIN: CHARACTER-SYMBOLS AS PRIMARY FACTORS OF INTERSUBJECTIVE CONSTITUTION IN THE MONK}

The fool hath said in his heart: There is no God. They are corrupt and are become abominable in their ways: there is none that doth good, no, not one. . . Their throat is an open sepulcher: with their tongues they acted deceitfully: the poison of asps is under their lips. Their month is full of cursing and bitterness; their feet are swift to shed blood. Destruction and unhappiness in their ways: and the way of peace they have not known. There is no fear of God before their eyes. (Douay-Rheims The Holy Bible Psalm 14:1-3.)

When we perceive Ambrosio standing before a painting of the Virgin Mary in his abbey-chamber in The Monk, we discover him lusting after the holy image in an act that thrusts us into a contradiction of titillation and horror. After all, Mary, the mother of Jesus, certainly represents an archetypal symbol-pureness, innocence, virginity, holiness, and godliness--in our culture, as it did during the Spanish Inquisition, when The Monk takes place. This, of course, does not impede Ambrosio's designs: "Were I permitted to twine round my fingers those golden ringlets, and press with my lips the treasures of that snowy bosom!" he exclaims as he carnally contemplates the image (Lewis 40). We find throughout the text that Ambrosio admires perceived and actual divinity in female characters such as Matilda and Antonia, whom he later destroys after robbing her of her innocence, her divinity, as we shall determine later in this chapter. Yet, it is the very idea of divinity and Ambrosio's desire to physically pollute the feminine divine that initially thrusts him down the phenomenological path to damnation and results in his physical and spiritual damnation at the end of Lewis's text. Antonia as Eve, Matilda as the Temptor, Ambrosio himself as Adam-many of Lewis's characters as 
symbols of the Fall of Man, coupled with the physical symbolism of places such as the Abbey Garden as Eden and its underground sepulchers as Hell, lead to Ambrosio's false intersubjective constitution, or the primary acts whereby Ambrosio's self is shaped by the people and events surrounding him, and his eventual self-damnation in consciousness. Because Ambrosio's self is shaped by these symbols and events of objective sin, or original sin that applies to all humankind and is symbolized in the Biblical legend of the Fall of Man, it is important that these be interpreted as the foundation to Ambrosio's phenomenological path to damnation; these symbols appear at various stages of this path and are integral to the establishment of its various steps. Ambrosio's self is inextricably intertwined with these symbols in the incessant process of intersubjective constitution, a process by which the self intends these symbols, projects the self toward them, and reaffirms its identity through the multiple channels of communication between the self and other elements in the Lifeworld, which, for our purposes, is the fictive world in which Ambrosio exists.

The Traditional Hermeneutical Approach vs. Hermeneutic-Phenomenology

The traditional hermeneutic approach specified by philosophers such as Friedrich Schleiermacher, Hans Georg Gadamer, and Rudolph Bultmann specifies that to understand a text, an interpreter must enter the "hermeneutic circle" by looking first to the text itself for meanings of symbols. Then, the interpreter should look at events in the author's lifetime, as well as the psyche of the author, and reinterpret the symbols in light of this new information. The process is neverending and presents some challenges; for example, interpreters carry their own presuppositions with them when they enter the 
hermeneutic circle, and these presuppositions can alter the meanings of symbols in the text, although Gadamer maintains an interpreter need only acknowledge the presuppositions she brings to the interpretation (282).

Literary critics such as Hogle, Tienhooven, and others explored in Chapter 1 have turned to events in Lewis's lifetime to aid understanding of The Monk, and this certainly would resemble a traditional hermeneutical approach to interpretation of the text. However, the object of study for this work presents particular problems literary critics have yet to encounter, and a straight hermeneutical approach to Lewis's work and Ambrosio's consciousness would prove fallacious. For this work, which will establish the phenomenological path to damnation in Ambrosio's consciousness, we will be analyzing the progression of the consciousness of a fictive character who exists in a fictive world of Lewis's creation. Obviously Ambrosio had no access to Lewis's world; thus, it would be fallacious to thoroughly analyze Lewis's world or even Lewis's background for an interpretation of the symbols in Ambrosio's consciousness. In addition, it would be fallacious to equate Lewis's consciousness with Ambrosio's consciousness because authors are capable of creating fictive consciousnesses completely different from their own. However, Ambrosio's consciousness is an incomplete one that includes gaping holes regarding the progression of his consciousness of the divine and anti-divine throughout his life, until we first encounter him early in Lewis's text.

To surmount this research dilemma, we will approach our interpretation by first establishing an "ideal type" religious consciousness that existed during the Spanish Inquisition, probably between 1500 and the end of the Inquisition, which is typically set circa 1660. The "ideal type" is an idea coined by sociologist Max Weber (1864-1920). 
According to Weber, "The ideal typical concept will help to develop our skill in imputation in research: it is no 'hypothesis' but it offers guidance to the construction of hypotheses. It is not a description of reality but it aims to give unambiguous means of expression to such a description" (Varenne, par. 2). Although Weber's idea of the "ideal type" originally applied to sociology, it will greatly aid this analysis of Ambrosio's intersubjective constitution (or the interplay of his self and symbols surrounding him) with the symbols in his fictive Lifeworld. Weber's "ideal type" is constructed by emphasizing "logical or consistent traits of a given social item," and although the traits do not exist in reality, they are measures used in comparing social phenomenon (Elwell, "Glossary"). Approaching Ambrosio as an ideal type will enable us to assume some information regarding Ambrosio's consciousness that is missing in Lewis's text, such as texts with which he would have been familiar and his ideas and values regarding the divine and anti-divine. It will also expand Ambrosio from a one- or two-dimensional character in a fictive text to a character with a consciousness similar to the consciousness we experience in our Lifeworld, or the world we experience. When we examine symbols and myths and how they are experienced and interpreted by members of the Lifeworld, we engage in hermeneutic-phenomenology, as discussed in Chapter 1 of this work. We turn now to the ideal-type religious consciousness in the Lifeworld of the Spanish Inquisition.

Religious Consciousness in a Monk's Lifeworld during the Spanish Inquisition, 15001660

That there is one holy, catholic, and apostolic church we are bound to believe and hold, our faith urging us, and this we do firmly believe and simply confess; and that 
outside this church there is no salvation or remission of sins. (Pope Boniface VIII, Swanson 1)

We begin establishing the "ideal type" religious consciousness that existed during the Spanish Inquisition with an examination of the role of religion in the life of ecclesiasts during that period. According to R.N. Swanson, author of Religion and Devotion in Europe c. 1215-1515, there existed a hierarchy of religious authority from the Pope down to parish priests (1). The basic tenets of religious belief regarding the church were expressed in the Apostle's Creed, which was meant to be known by all laypeople (and obviously all ecclesiasts) throughout the period. The Creed was supposedly written by the Apostles:

I believe in God the Father almighty, maker of heaven of earth; and in Jesus Christ, his only Son, our Lord, who was conceived by the Holy Ghost, born of the Virgin Mary, suffered under Pontius Pilot, was crucified, dead, and buried; he descended into Hell. The third day he rose again from the dead; he ascended into Heaven; and sits on the right hand of God the Father almighty; from thence he shall come to judge the living and the dead.

I believe in the Holy Ghost, the holy catholic church, the communion of saints, the forgiveness of sins, the resurrection of the body, and the life everlasting. (Swanson 16)

Despite uniformity of religious views in the Catholic church, there was a churchadmitted problem with recruiting good clergy members, and this is evidenced in The Monk when Lewis writes that Ambrosio was left at the monastery door as an infant. It is possible some clergy members received no formal training; however, "Monks were often sent to universities for study, and so contributed to theological development: at Oxford, for example, the Durham monks had their own college, while Osney abbey provided a base for members of the Augustinian order. The larger houses, like Durham, also maintained large libraries which kept them well aware of theological arguments, even if not always the most up-to-date," Swanson writes (59). Those in the religious orders had a 
large impact on daily life, although near the end of the Spanish Inquisition there were complaints that the regulars participated too much in the world (107); Ambrosio must have been aware of this because he prides himself on not leaving the monastery except to address the congregation. The houses of the various religious orders sheltered pilgrims, served as mausoleums, offered charity to those in need, and offered religious instruction to laity (107). A monk's daily life was filled with various devotional practices and ceremonies such as Matins, the early morning or evening prayer service during which various psalms were chanted. Monks also engaged in scholastic activities such as reading the Latin Vulgate and other religious documents and translating those texts into various languages.

Literature available to the ideal type religious consciousness during the Spanish Inquisition reveals much about the objective mind's attitudes toward religion during the period. The ideal type religious consciousness that existed during the Spanish Inquisition would probably have had access to a myriad of religious texts because of a literary explosion in the eleventh and twelfth centuries (Witchcraft 58). Religious discourse is littered with references to superstition and witches, as is the fictive Lifeworld of Ambrosio in The Monk. Augustine, Aquinas, and other religious leaders of the Catholic faith gave a place to demons and witches in their cosmologies of the world (Witchcraft 6). The role of Satan in the Fall of Man changed from the early Middle Ages to the late period, and it is Satan's role in The Monk that helps place the text as set in the late Middle Ages; Satan, as the driving force behind Ambrosio's damnation in his role as the great Temptor, is a figment of late Middle Ages thought (7). The role of demons changed as well, from lieges associated with Satan to instruments that interacted with humans and 
helped bring about their downfall. In fact, the changing objective mind of Middle Ages

culture toward Satan and demons led in part to the "witch craze" and religious superstition of the period:

The 'craze' deeply touched the life of every European. Rural villages, remote mountain farms, and the greatest and most economically complex citieswith, to be sure, many exceptions and varieties-equally expressed ever greater evidence of shared helplessness and terror. The ensuing malevolence among neighbors and families sustained suspicion, accusation, and persecution, sometimes over a period of two or three generations in a single place. (15)

With the establishment of the Spanish Inquisition in 1481, religious leaders actively sought to reveal and punish alleged witches. As a religious leader, Ambrosio would obviously be aware of the Inquisition and its reputation and power, as well as the objective mind of his culture toward the role of Satan and demons in the lives of mortals. ${ }^{1}$

One of the most revered Catholic writers, St. Augustine, writes in De Docrina

Christiana in 395-98 of the fate of humans who interact with God's anti-agents on earth:

In this way it happens that, by some inscrutable divine plan, those who have a desire for evil things are handed over to be deluded and deceived according to what their own wills deserve. They are deluded and deceived by corrupt angels, to whom in God's most excellent scheme of things this lowest part of the world has been subjected by the decree of divine providence. ... So in all these teachings we must fear and avoid this alliance with demons, whose whole aim, in concert with their leader, the devil, is to cut off and obstruct our return to God (46)

The same doctrine is echoed by Caesarius of Arles who lived as a monk in the monastery of Lerins, who became bishop of Arles. ${ }^{2}$ Burchard, Bishop of Worms expresses it in "The Corrector, sive Medicus" in 1008-12, but adds a distinctly anti-feminine touch when he speaks of witches as women; note the comparison when Ambrosio labels Matilda and Antonia a "witch" after he transgresses with them. In 1270, Jacobus de Voraigne writes a supposedly true account in "The Golden Legend of Justina" of how a young woman who 
is converted to Christianity endures many trials by Satan and his demons, who appear disguised as various humans, to no avail (Witches 81 ). Culture's emphasis on the active role Satan and his minions play in the damnation of humankind continues even through the writings of St. Thomas Aquinas. In an Aristotelian twist, Aquinas emphasizes virtue in his The Summa contra gentiles: "For it is the mark of an ill-disposed mind to countenance things contrary to virtue," he writes (95). In Summa Theologica, Aquinas warns how demons tempt man when he writes, "The Apostle says [Eph. Vi. 12]: Our wrestling is not against flesh and blood; but against principalities and powers, against the rulers of the world of this darkness, against the spirits of wickedness in the high places .

. The assault itself is due to the malice of the demons, who through envy endeavor to hinder man's progress; and through pride usurp a semblance of Divine power, by deputing certain ministers to assail man...." (95-6). However, Aquinas points out that demons know what happens "outwardly" with humans, but do not know the inward disposition of man; "hence the devil tempts, in order to explore this inward disposition of man, so that he may tempt him to that vice to which he is most prone" (99).

Lewis himself hints at Ambrosio's austere religious upbringing and the superstition that surrounded him in his fictive Lifeworld. Lewis's narrator tells us that outside the monastery, Ambrosio "would have shown himself possessed of many brilliant and manly qualities... He had a Warrior's heart, and he might have shown with splendour at the head of an Army. There was no want of generosity in his nature ...." (Lewis 236). We are reminded that Ambrosio's parents saw these qualities in him as a young child, but that he lost his parents and was given to a friend who relegated him to the care of the Superior of the Capuchins. This abbott persuaded Ambrosio that happiness 
lay only within the walls of the monastery, and Ambrosio's highest ambition became "to deserve admittance into the order of St. Francis" (237). However, that admittance is part of Ambrosio's doom:

His Instructors carefully repressed those virtues, whose grandeur and disinterestedness were ill-suited to the Cloister. Instead of universal benevolence He adopted a selfish partiality for his own particular establishment: He was taught to consider compassion for the error of Others as a crime of the blackest dye: the noble frankness of his temper was exchanged for servile humility; and in order to break his natural spirit, the Monks terrified his young mind, by placing before him all the horrors with which Superstition could furnish them: They painted to him the torments of the Damned in colours the most dark, terrible, and fantastic, and threatened him at the slightest fault with eternal perdition. (237)

This passage supports our use of the ideal type in an analysis of Ambrosio's path to selfdamnation; Lewis has described many of the attributes religion scholars attest to the medieval religious mind. However, we must note here that Lewis's ideas of Catholicism and the Spanish Inquisition, when considered in light of the objective mind of his culture (the anti-Catholic prejudice of $18^{\text {th }}$-century protestant England), would most likely not have favored Catholicism, so the words chosen in Lewis's text should be no surprise. Although it is nearly impossible to determine what specific texts Lewis read, it is reasonable to assume he would have been familiar with John Foxe's Book of Martyrs, an intimate account of the sufferings and persecutions of Christians. However, Lewis would certainly have been aware of the objective mind of his culture toward Roman Catholicism, which had regressed into a minority religion by about 1770 , when the Roman Catholic population in Britain was about 80,000 (McCalman 94). McCalman writes: "The Church of England, which assuredly claimed the allegiance of most English men and women, was in theory the ecclesiastical parallel to civil society" (94). According to the Test Acts of 1673 and 1678, Roman Catholics could not hold office or sit in 
parliament. In 1736, William Warburton (1698-1779) published The Alliance between

Church and State, in which he maintained the ruler should establish the religion for his subjects (McCalman 93). While this would have been before Lewis's actual time, the anti-Catholic sentiment begun during this period remained a significant influence in Britain and with little doubt influenced the anti-Catholic sentiment in The Monk. With these ideas in mind, we move toward an interpretation of the character-symbols that lead to Ambrosio's damnation in consciousness, but we must first address the specific myth wherein the characters function.

Ricoeur: The Function of the "Adamic" Myth

Thus, there is a circular relation among all the symbols: the last bring out the meaning of the preceding ones, but the first lend to the last all their power of symbolization. (The Symbolism of Evil 152)

According to Ricoeur, we must place our interpretation of symbols in relation to a myth to achieve a complete, meaningful interpretation. Ricoeur examines several types of myths in The Symbolism of Evil, but we will focus on Ricoeur's idea of the "Adamic" myth because it specifically addresses the Fall of Man from the grace of God and essentially parallels Ambrosio's fall from grace in The Monk. "The first function of the myths of Evil is to embrace mankind as a whole in one ideal history," Ricoeur writes (Evil 162). "By means of a time that represents all times, 'man' is manifested as a concrete universal; Adam signifies man. 'In' man, says Saint Paul, we have all sinned" (Evil 162-3). The human type, in which we see ourselves, is recapitulated in the myth; along these lines and through character-symbols, Ambrosio is paralleled with Adam in the Adamic myth. 
To understand the function of the Adamic myth in Ambrosio's consciousness, we must examine it in relation to the holy text with which the ideal-type religious consciousness would be familiar: the Vulgate, or, for our purposes, the Douay-Rheims The Holy Bible. It is important to note here that if we were directly equating Ambrosio's consciousness with that of Lewis, the preferred text would be the King James version of The Holy Bible; however, as noted earlier, it is fallacious to equate Lewis's consciousness with that of Ambrosio. The Douay-Rheims The Holy Bible begins the story of Humankind on the sixth day of creation (Genesis 1:27); "And the Lord God had planted a paradise of pleasure from the beginning: wherein he placed man whom he had formed" (Genesis 2:7). However, God warned Adam and his "helper," Eve, not to eat of the tree of the knowledge of good and evil, or they would die (Genesis 2:17). The story continues in Genesis 3:

Now the serpent was more subtle than any of the beasts of the earth which the Lord God had made. And he said to the woman: Why hath God commanded you, that you should not eat of every tree of paradise? / And the woman answered him, saying: Of the fruit of the trees that are in paradise we do eat: / But of the fruit of the tree which is in the midst of paradise, God hath commanded us that we should not eat; and that we should not touch it, lest perhaps we die. / And the serpent said to the woman: No, you shall not die the death. / For God doth know that in what day soever you shall eat thereof, your eyes shall be opened: and you shall be as Gods, knowing good and evil. / And the woman saw that the tree was good to eat, and fair to the eyes, and delightful to behold: and she took of the fruit thereof, and did eat, and gave to her husband who did eat. / And the eyes of them both were opened: and when they perceived themselves to be naked, they sewed together fig leaves, and made themselves aprons. (Douav-Rheims The Holv Bible Genesis $3: 1-7)$

This, then, is the heart of the Adamic myth, the specific moment of the fall of humankind. Ricoeur maintains the function of the Adamic myth is to separate the origins of good and evil; "it is that which makes man a beginning of evil in the bosom of a creation which has already had its absolute beginning in the creative act of God," he writes (Evil 233). If 
man is not responsible for evil, then certainly God is; He must have created humankind with a propensity for evil. However, humankind was created in God's image, according to Genesis, which implies God has a propensity for evil. Ricoeur writes:

It is the holiness of God that reveals the abyss of sin in man; but, on the other hand, if the root of $\sin$ is in the "nature," in the "being" of man, then the sin revealed by the holiness of God returns upon Him and accuses the Creator of having made man evil. If I repent of my being, I accuse God in the same moment in which he accuses me, and the spirit of repentance explodes under the pressure of that paradox. Thus, the myth appears at a point of high tension in the penitential experience; its function is to posit a "beginning" of evil distinct from the "beginning" of creation, to posit an event by which sin entered into the world and, by sin, death. The Myth of the Fall is thus the myth of the first appearance of evil in a creation already created and good. (Evil 242-3).

In addition, the myth introduces the character of the serpent and thus creates a separate entity responsible for Evil and the Fall of Man.

Ricoeur maintains that to understand the Adamic myth, we must first understand that it is precisely that: a myth. "It must be well understood that the question, Where and when did Adam eat the forbidden fruit?, no longer has meaning for us; every effort to save the letter of the story as a true history is vain and hopeless," he writes (Evil 235). Ricoeur calls this a "clear attitude," yet maintains the story of the Fall "has the greatness of myth," which means it has more meaning than a true history (235). The only avenue for interpretation of the myth is through the symbols and character-symbols in the myth, and these can only be read in relation to the myth itself. It is important to note that, for this work, we will only examine the character-symbols in The Monk and how they correspond to character-symbols in the Myth of the Fall as they would be interpreted by Ambrosio's consciousness, which we have equated with the ideal-type religious consciousness during the Inquisition. Ambrosio would obviously regard the Myth of the Fall of Man as actual history, so we will depart from Ricoeur at this point and "read" the 
myth and its symbols as historical fact, as they most likely would have been interpreted by Ambrosio's consciousness. In addition, to address the myth's complexities, such as the possibility that Adam had a first wife, Lilith, would encumber our interpretation of the symbols; thus, while we acknowledge these possibilities, we will not address them. With this information in mind, we now move to an interpretation of the primary symbols in The Monk that drive Ambrosio's self-damnation in consciousness. To test Ricoeur's theories, we begin each interpretation with language from Lewis's text as Ricoeur specifies, then layer our interpretation of the "ideal type" of monk who lived during the Spanish Inquisition. The primary character-symbols selected are those which apparently drive Ambrosio to his doom and with which his self is falsely intersubjectively constituted throughout the text.

Ambrosio: Adam, the First Man

But the dreams of the former night were repeated, and his sensations of voluptuousness were yet more keen and exquisite. The same lust-exciting visions floated before his eyes: Matilda, in all the pomp of beauty, warm, tender, and luxurious, clasped her to his bosom, and lavished upon him the most ardent caresses. He returned them as eagerly, and already was on the point of satisfying his desires, when the faithless form disappeared, and left him to all the horrors of shame and disappointment. (Lewis 84)

At first thought, it may seem odd to analyze the symbolism of the character who unconsciously examines the symbolism of other characters who lead him to his own fate. However, even though Ambrosio is the cogito of this analysis, it is important to note that during intersubjective constitution, the self consistently looks at its relationship to other people, events, and environments around it and constantly reinterprets itself even as it posits its own existence. In light of Ricoeur's idea of interpreting symbols in their relation to myth, Ambrosio would obviously see himself as a player in the Myth of the 
Fall; if he did not, it would be impossible for him to interpret the symbolism of people and events around him in relation to that myth. There must be a starting point for this, however, and because Ambrosio's is a fictive consciousness, we begin where we first meet him in Lewis's text:

He was a man of noble port and commanding presence. His stature was lofty, and his features uncommonly handsome. His Nose was aquiline, his eyes large black and sparkling, and his dark brows almost joined together. His complexion was of a deep but clear Brown; Study and watching had entirely deprived his cheek of colour. Tranquility reigned upon his smooth unwrinkled forehead; and Content, expressed upon every feature, seemed to announce the Man equally unacquainted with cares and crimes. He bowed himself with humility to the audience: Still there was a certain severity in his look and manner that inspired universal awe, and few could sustain the glance of his eye at once fiery and penetrating. Such was Ambrosio, Abbot of the Capuchins, and surnamed, 'The Man of Holiness.' (18)

Ambrosio's appearance certainly reflects the ideal type religious consciousness during the Spanish Inquisition; however, his beginnings are clouded in controversy in the text. The monks "have not hesitated to publish, that $\mathrm{He}$ is a present to them from the Virgin" (17), as a secret shrouds the events behind Ambrosio's arrival at the monastery: "No one has ever appeared to claim him, or clear up the mystery which conceals his birth" (17). Until near the end of his life, Ambrosio's entrance into this world is a mystery, as is his creation; like Adam, he seems to come direct from divinity.

Despite Ambrosio's mysterious beginnings on Earth, it is not difficult to determine how he sees his "self" at the opening of Lewis's text. He delivers his oration clearly and strongly; when he descends the pulpit, he is surrounded by admirers who. throw themselves at his feet and kiss the hem of his garment in a holy ritual reminiscent of the worship of divinity. Lewis's narrator paints the picture of a strict religious idol, a person solid in his beliefs and strong in constitution. However, he also hints to us that 
aspects of the anti-Divine linger below the surface of Ambrosio's self. "The Abbott, smiling at their eagerness, pronounced his benediction, and quitted the Church, while humility dwelt upon every feature. Dwelt She also in his heart?" (20) We get a glimpse of one of the traits of Ambrosio's authentic self, as opposed to his public self, after he returns to his abbey chamber alone: "He looked round him with exultation, and Pride told him loudly, that He was superior to the rest of his fellow-Creatures" (40). "Who, thought he, 'Who but myself has passed the ordeal of Youth, yet sees no single stain upon his conscience? Who else has subdued the violence of strong passions and an impetuous temperament, and submitted even from the dawn of life to voluntary retirement? I seek for such a Man in vain. I see no one but myself possessed of such resolution. Religion cannot boast of Ambrosio's equal!"' (40) Ambrosio's image of his self is one of nonstain, non-blemish - he holds a mental image of his self as a perfect divine entity, even though, as we shall see in subsequent chapters, his discourse indicates he is aware of the inheritance of original sin and the public need for humility. In essence, this can be equated to philosopher Jean Paul Sartre's doctrine of "bad faith." Part of Ambrosio's bad faith may have been established by the importance of his role as an abbott; priests during Ambrosio's lifetime "could determine whether a man should spend eternity in heaven or in hell," and could even shorten time a soul spent in purgatory by selling indulgences, or saying masses for the soul in return for a suitable monetary payment (Russell 408).

However, it is through Ambrosio's discourse in Lewis's text and his relation to other character $\sim$ symbols in the Myth of the Fall that Ambrosio most parallels Adam. The Adamic myth illustrates humankind's first response to disobeying the law: when God confronts Adam, he immediately points to Eve, saying, "The woman, whom thou gavest 
me to be my companion, gave me of the tree, and I did eat" (Douay-Rheims The Holy Bible Genesis 3:12). When Ambrosio "falls" at various points in Lewis's text, he immediately lays the blame elsewhere than himself. When Ambrosio first has sexual relations with Matilda, the narrator says that "He forgot his vows, his sanctity, his fame: He remembered nothing but the pleasure and opportunity," (Lewis 90) much like Adam forgot God's command not to eat fruit from the tree of the knowledge of good and evil. Lewis's narrator recounts Ambrosio's reaction after he first "sins" with Matilda: "Pleasure fled, and Shame usurped her seat in his bosom... His perjury presented itself before him: He reflected upon the scene which had just been acted, and trembled at the consequences of a discovery" (223)-is this not reminiscent of Adam's reaction after eating from the tree? "And when they heard the voice of the Lord God walking in paradise at the afternoon air, Adam and his wife hid themselves from the face of the Lord God, amidst the trees of paradise" (Douay-Rheims The Holy Bible Genesis 3:8). Also, like Adam, Ambrosio immediately suppresses his responsibility for his actions and shifts it to Matilda in words Adam might have used to Eve: “ 'Dangerous Woman!' said He; 'Into what an abyss of misery have you plunged me! . . Fool that I was, to trust myself to your seductions! What can now be done? How can my offence be expiated? What atonement can purchase the pardon of my crime? Wretched Matilda, you have destroyed my quiet forever!'” (223)

Throughout Lewis's text, however, we see Ambrosio willfully commit sin after sin with the encouragement of Matilda, engaging in Sartre's idea of "bad faith" and verifying medieval writer St. Anselm of Canterbury's idea that the will is the primary tool of sin. In "Virgin Conception and Original Sin," Anselm writes: 
Thus, when Adam sinned, we all sinned in him, not because we ourselves, who did not yet exist, sinned, but because we were to be born from him: it was then that the necessity was created that when we came to be we should sin, because 'through the sin of one disobedient man many were made sinners.' For the blame attaches ... to the ill-will. (Anselm 367)

This idea of the will, which will culminate in Ricoeur's idea of the "servile will," or the will enslaved to the human passions (as were the wills of Adam and Eve), will be an integral factor in Ambrosio's self-damnation, as we shall see in subsequent chapters of this work. An examination of Ambrosio's self in relation to Matilda will further solidify his role as Adam in the Myth of the Fall

Matilda: Symbolic Progression from "Eve the Companion" to "Eve the Temptress" to the "Serpent"

As she uttered these last words, She lifted her arm, and made a motion as if to stab herself. The Friar's eyes followed with dread the course of the dagger. She had torn open her habit, and her bosom was half exposed. The weapon's point rested upon her left breast: And Oh! That was such a breast! The Moon-beams darting full upon it, enabled the Monk to observe its dazzling whiteness. His eye dwelt with insatiable avidity upon the beauteous Orb. (Lewis 65)

There is little doubt that Matilda is one of the driving character-symbols behind Ambrosio's self-damnation. Matilda's permeable symbolic boundaries lend difficulty to interpreting her as a character-symbol but are essential to establishing the steps on the path to Ambrosio's self-damnation. For the symbol of Matilda as Companion, a homosexual air lingers over her relationship as Rosario with Ambrosio before she reveals herself to be a woman. Lewis's narrator states:

To him [Ambrosio] He looked up with a respect approaching idolatry: He sought his company with the most attentive assiduity, and eagerly seized every means to ingratiate himself in his favour. In the Abbott's society his Heart seemed to be at ease, and an air of gaiety pervaded his whole manners and discourse. Ambrosio on his side did not feel less attracted towards the Youth; With him 
alone did He lay aside his habitual severity. When $\mathrm{He}$ spoke to him, $\mathrm{He}$ insensibly assumed a tone milder than was usual to him; and no voice sounded so sweet to him as did Rosario's. (42)

As Rosario, Matilda serves the initial function that Eve served for Adam: "And the Lord God said: it is not good for man to be alone; let us make him a help like unto himself' (Douay-Rheims The Holy Bible Genesis 2:18). Rosario is the favored companion of Ambrosio, much as Eve was formed to be a companion for Adam, according to the Adamic myth. In addition, it is as Rosario that Matilda begins to lead Ambrosio astray as she urges him to keep her sex a secret and allow her to remain with him at the abbey. It is also interesting to note that according to the Adamic myth, Eve was formed from a rib of Adam; along these lines, we will see the blurring of identity structures of Ambrosio and Matilda as Ambrosio assumes the role of sophist with Antonia, much as Matilda assumes with him. In gothic art, an example of Eve in the midst of changing from Eve as Companion to Eve as Temptress is evidenced in Henry Fuseli's "Satan's First Address to Eve" (1802-right, Tomoroy plate X). Satan appears as a huge Figure 1: "Satan's Address to Eve"

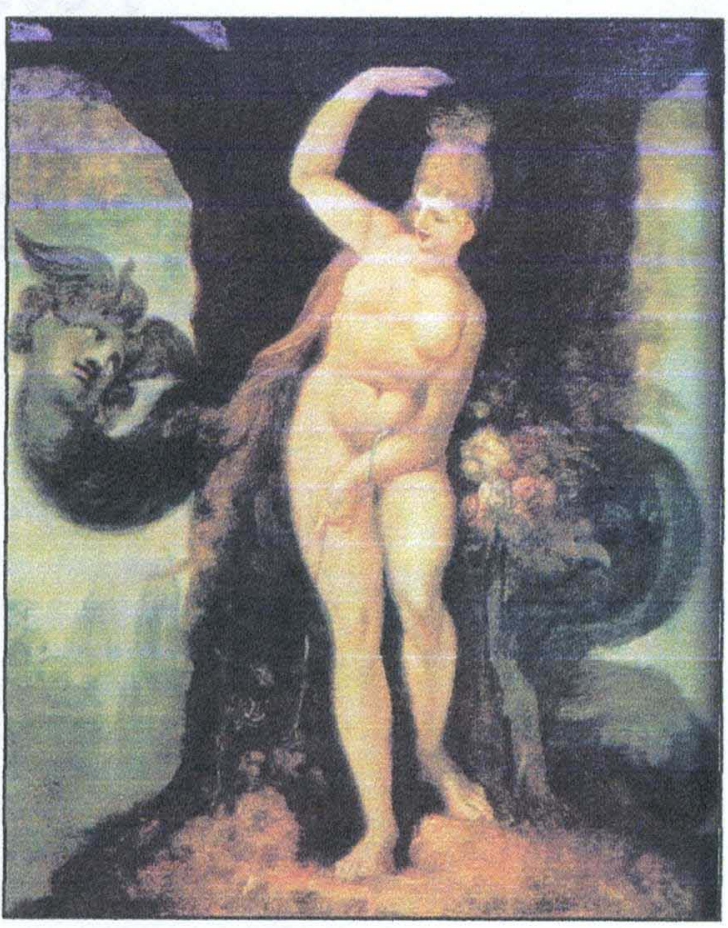
serpent wrapped around a tree. Eve has her arm elevated as if Satan has surprised her, and yet she exhibits no fear. Who would fear something so human, even beautiful? We must note here how at no point does Ambrosio fear Matilda, even when she regresses (or 
progresses) from Eve the Companion to Eve the Temptress. We shall examine this particular work of art in more detail in Chapter 6.

It is when she unveils herself as a woman, however, that Rosario/Matilda's character-symbol begins to move from Eve the Companion to Eve the Temptress; not only does she awaken Ambrosio's slumbering sexual passion, but her manipulation of Ambrosio's self rises to the crescendo situation which leads Ambrosio to begin his phenomenological path to damnation. After Rosario has revealed himself to be Matilda and begs to be allowed to remain in Ambrosio's company at the abbey, Lewis's narrator states that Ambrosio "perceives not that his vanity was flattered by the praises bestowed upon his eloquence and virtue; that He felt a secret pleasure in reflecting that a young and seemingly lovely Woman had for his sake abandoned the world, and sacrificed every other passion to that which He had inspired; Still less did he perceive that his heart throbbed with desire, while his hand was pressed gently by Matilda's ivory fingers" (62). Matilda's role as Eve the Temptress is further solidified by Ambrosio himself when he sees her the first time without her cowl: "Ambrosio dared to look on her but once: That glance sufficed to convince him how dangerous was the presence of this seducing Object" (78). Ambrosio offers up prayers to St. Francis to assist him in this "dangerous trial," to no avail: he soon falls prey to Matilda's charms, much as Adam ate the fruit offered by Eve. Even though Ambrosio's self posits blame for his failings on Matilda, St. Anselm would disagree, and Ambrosio, as the ideal type religious consciousness, would have been familiar with Anselm's writings. The sin of Adam and Eve fell upon Adam more than Eve, Anselm maintains: "If Eve alone and not Adam had sinned, it would not have been the fate of the whole human race to die, but Eve's alone," he writes in "Virgin 
Conception and Original Sin." "For God could then have fulfilled his purpose by making another woman from Adam, in whom he had created the seed of every human being" (Anselm 369). Thus, although Ambrosio's self posits itself in relation to Adam in the Myth of the Fall, it operates in "bad faith" by refusing to acknowledge the superior role of the man, or Adam, in the first sin. It is important to note a contradiction here, however, in light of the Malleus Maleficarum, or The Hammer of Witches, written by Heinrich Kramer and Jacob Sprenger in 1487, which is important to this work because of the witch craze that would have been prevalent in the ideal type religious consciousness during the Spanish Inquisition. The Malleus maintained that superstition was chiefly found in women: "All wickedness is but little to the wickedness of a woman.... Therefore a wicked woman is by her nature quicker to waver in her faith, and consequently quicker to abjure her faith, which is the root of witchcraft" (Kramer 185). The Malleus also maintained there was a defect in the first woman, Eve, because she was formed from a bent rib. Thus, Ambrosio's blame of Matilda for his fall is part of the contradiction that must have existed in the ideal type religious consciousness.

With this in mind, Matilda's role as Eve the Temptress begins to shift to that of the Serpent after Ambrosio yields to her physical temptations and tastes the pleasures of the flesh. After Ambrosio rises and blames her for their mutual transgression, Matilda assumes the role of a sophist, much as the Serpent in the Garden of Eden. After Eve explains that God will not allow her and Adam to eat fruit from the Tree of the Knowledge of Good and Evil because they would die, the Serpent replies: "No, you shall not die the death. / For God doth know that in what day soever you shall eat thereof, your eyes shall be opened: and you shall be as Gods, knowing good and evil" (Douay-Rheims 
The Holy Bible Genesis 3:5). The serpent's logic persuades Eve to eat from the tree and to give fruit from the tree to Adam, in effect sealing their doom. After Ambrosio breaks his vows of chastity with Matilda, she assumes the role of a sophist, employing dubious logic to persuade Ambrosio to continue transgressing against his vows and God:

Have I not shared in your guilt? Have you not shared in my pleasure? Guilt, did I say? In what consists ours, unless in the opinion of an ill-judging World? Let that World be ignorant of them, and our joys become divine and blameless! Unnatural were your vows of Celibacy; Man was not created for such a state; and were Love a crime, God never would have made it so sweet, so irrestible! Then banish those clouds from your brow, my Ambrosio! Indulge in those pleasures freely, without which life is a worthless gift; Cease to reproach me with having taught you, what is bliss, and feel equal transports with the Woman who adores you! (Lewis 224)

In essence, however, Matilda continues and yet moves beyond the role of Eve because she tempts Ambrosio relentlessly throughout the text, and Ambrosio himself notices the change in her personality: "But a few days had past, since She appeared the mildest and softest of her sex, devoted to his will, and looking up to him as to a superior Being. Now She assumed a sort of courage and manliness in her manners and discourse but ill calculated to please him. She spoke no longer to insinuate, but command: $\mathrm{He}$ found himself unable to cope with her in argument...." (Lewis 231). Thus, Matilda's changing role from Eve the Companion to Eve the Temptress and to the Serpent is integral to Ambrosio's journey down his phenomenological path to damnation.

It is worth mentioning here how critics such as Hogle and Tienhooven have equated themes in The Monk with anti-Catholicism and the French Revolution, and how popular opinion regarding Marie Antoinette, the French queen of Louis XVI, specifically mirrors Ambrosio's thoughts regarding women in The Monk. As we shall see, at each step of his phenomenological path to damnation, Ambrosio points the finger of blame 
toward a female in the text; in Ambrosio's consciousness, Matilda, Antonia, and Elvira all become active agents endeavoring to damn him. While Burke, in Reflections on the Revolution in France (1790), Figure 2: "French Democrats Surprising Royal Runaways"

pictures the mob that overthrows the French monarchy as base, those with counter-thoughts pictured the queen as responsible for the downfall of France. The idea of Marie-Antoinette as the "Other" is depicted in one of cartoonist James Gillray's works,

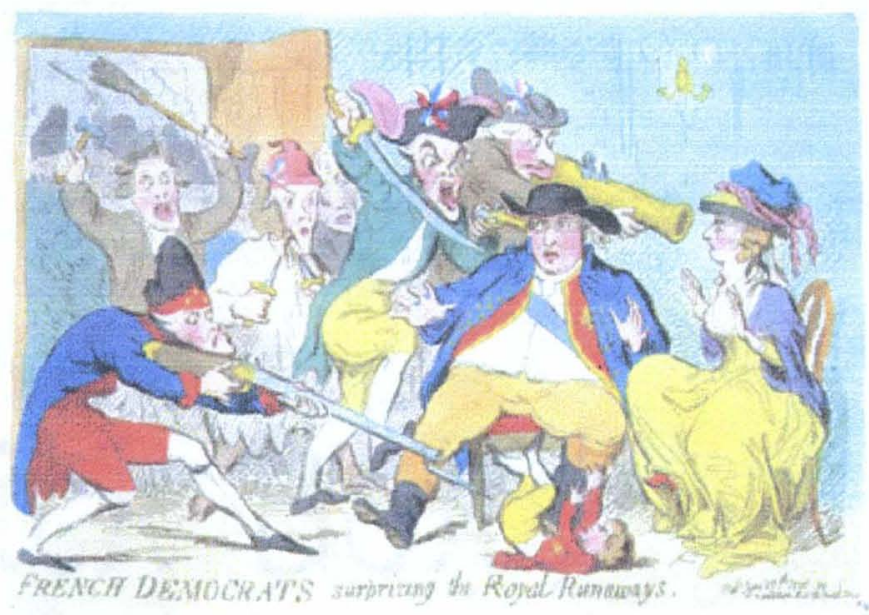
"French Democrats Surprising Royal Runaways." Gillray, an English illustrator (17561815), published his works during the "golden age" of English caricature, 1770-1820 (Princeton University). Note the emaciated bodies of the revolutionaries in contrast to the plump forms of Louis XVI and his queen, in addition to how the primary instrument of intimidation, obviously phallic, is aimed directly at the head of the queen as opposed to the king. Certainly the political structure of the day supported Lewis's idea of woman as evil temptress. We now move to an analysis of one of the primary physical instruments of Ambrosio's damnation in consciousness: the abbey garden.

The Abbey and the Abbey Garden: The Garden of Eden

He approached the Bush, and stooped to pluck one of the Roses. Suddenly He uttered a piercing cry, started back hastily, and let the flower, which He already held, fall from his hand. .. . 'I have received my death!' He replied in a faint voice; 'Concealed among the Roses... A Serpent.... (Lewis 71) 
In the Douay-Rheims The Holy Bible, the Garden of Eden is described as a paradise containing the most lush and beautiful trees, with four rivers to nourish them as well as Adam and Eve. It serves as the scene for the Adamic myth and the Myth of the Fall, and the Abbey Garden in The Monk parallels it in its physical description and the events that occur there. After Ambrosio confronts Agnes with the note she has dropped regarding her relationship with Don Raymond, he retreats to the Abbey Garden to replenish his spirit (Lewis 50):

In all Madrid there was no spot more beautiful or better regulated. It was laid out with the most exquisite taste; The choicest flowers adorned it in the height of luxuriance, and though artfully arranged, seemed only planted by the hand of Nature: Fountains, springing from basons of white marble, cooled the air with perpetual showers; and the walls were entirely covered by Jessamine, vines, and Honeysuckles. (Lewis 50)

In addition to the physical resemblance to the Garden of Eden, the site parallels the ambiance of the Garden. Adam walked with God in the Garden in the afternoon air (Douay-Rheims The Holy Bible Genesis 3:8), and when Ambrosio approaches the Hermitage, a small grove surrounded by moss, ivy, and seats of turf as well as a "natural Cascade" that falls from a rock, "The universal calm had communicated itself to his bosom, and a voluptuous tranquility spread languor through his soul" (50), much as Adam may have felt when he walked with God. Yet, unlike Eden, there is a decidedly gothic air about the Abbey Garden; the song of the Nightingale and the fuil moon greet Ambrosio, lending a feeling of the dark and supernatural, possibly the attributes of an anti-Eden, to the location.

In addition to the physical resemblances, events in the texts also illustrate parallels between the locations. It is in the Abbey Garden that Ambrosio lays aside "the monk," or his religious self-protection, in favor of his friendship to Rosario: "Rosario, I 
lay aside the Monk, and bid you consider me as no other than your Friend, your Father" (Lewis 57). It is after Ambrosio figuratively lays aside his religious habit, his mantle of God, that temptation presents itself to him, much as it is presented to Adam after he lays aside God's commandment. In addition, the "holy space" of the Garden of Eden and the Abbey Garden is polluted by an unknown inquisitor-the Serpent in the Garden of Eden and Rosario/Matilda in The Monk-implying the holy space is not secure from corrupt forces. Adam had no reason to suspect he would be confronted with temptation, and neither did Ambrosio: both felt secure in their Holy Space until those spaces were polluted by outside forces.

One of the most striking events in the Abbey Garden that leads to its parallel to the Garden of Eden is when a serpent bites Ambrosio and begins the sequence of events that will lead Ambrosio to his self-damnation. The Abbey Garden is designed to protect its inhabitants from the potential transgressions of the outside world; however, much like the Garden of Eden, it provides the opportunity for the temptation for Ambrosio to slip after the serpent bites him. As Ambrosio lies on his deathbed after the serpent's bite, Matilda sucks the poison from his hand and secures her own demise; when Ambrosio has recovered and Matilda is on her deathbed, Ambrosio succumbs to her temptations and breaks his vows of chastity, thus releasing the lust that has reigned in his person for several years.

Antonia: Humankind's "Innocence" Before the Fall

'How!' said the Friar to himself; 'Antonia reads the Bible, and is still so ignorant?' But, upon a further inspection, He found that Elvira had made exactly the same remark. That prudent Mother, while She admired the beauties of the sacred writings, was convinced, that unrestricted no reading more improper could be permitted a young Woman. Many of 
the narratives can only tend to excite ideas the worst calculated for a female breast: Every thing is called plainly and roundly by its name; and the annals of a Brothel could scarcely furnish a greater choice of indecent expressions. (Lewis 259)

The character-symbol Antonia is the most difficult to read in relation to the Myth of the Fall because there is no direct Biblical character to mirror her role. However, Antonia represents a blurring of the human and divine that is characteristic of Adam and Eve before the Fall, and her innocence is certainly reminiscent of Adam's and Eve's innocence before their transgression.

If any character in The Monk can reasonably be compared with an angel, it is Antonia. The first description of her signifies a blurring of the human and the divine:

What a Seraph's head presented itself to his admiration! Yet it was rather bewitching than beautiful; It was not so lovely from regularity of features, as from sweetness and sensibility of Countenance. The several parts of her face considered separately, many of them were far from handsome; but when examined together, the whole was adorable. . . But then her lips were of the most rosy freshness; Her fair and undulating hair, confined by a simple ribband, poured itself below her waist in a profusion of ringlets. . . Her mild blue eyes seemed an heaven of sweetness, and the crystal in which they moved, sparkled with all the brilliance of Diamonds.... (Lewis 12).

To further solidify the signification between Antonia and an angel, Lewis shows her threatened by an unknown in Don Lorenzo's dream. The cathedral in his dream disintegrates into hell, and the creature, symbolic of Ambrosio, tries to drag Antonia to hell with him. However, Antonia sprouts wings and flies upward: "Animated by supernatural powers She disengaged herself from his embrace: But her white robe was left in his possession. Instantly a wing of brilliant splendour spread itself from either of Antonia's arms. She darted upwards, and while ascending cried to Lorenzo, 'Friend! We shall meet above?'" (Lewis 28). Antonia's nakedness in the dream is reminiscent of the innocence of Adam and Eve before the Fall. 
The blending of human and divinity is a primary component of the angel: "Thou hast made him a little less than the angels: thou hast crowned him with glory and honour, and hast set him over the works of thy hands" Psalm 8:6-7 states (Douay-Rheims The Holy Bible). Although angels are divine creatures, their power does not approach that of Christ; angels lie somewhere between humankind and supreme divinity. Angels have been messengers of God, such as the angel Gabriel who announced the birth of Christ. In addition, in Jacob's vision they are depicted as ascending and descending the ladder which stretches from earth to heaven while the Eternal Father gazes upon the wanderer below. It was an angel who found Agar in the wilderness (Genesis 16); angels drew Lot out of Sodom; an angel announces to Gideon that he is to save his people; an angel foretells the birth of Samson (Judges 13). Angels, like humans, were God-created: "praise ye him, all his angels: praise ye him, all his hosts ... for he spoke, and they were made: he commanded and they were created" (Douay-Rheims The Holy Bible Psalm 148:2, 5). Perhaps most importantly, angels seem to be the creatures that bridge some of the distance between God and humankind. This blending of human and divinity is especially prevalent in Antonia as she lies dying in Don Lorenzo's arms: she thinks nothing of herself and what she might face after death, but focuses instead on Lorenzo and his happiness:

She told him, that had She still been undefiled She might have lamented the loss of life; But that deprived of honour and branded with shame, Death was to her a blessing: She could not have been his Wife, and that hope being denied her, She resigned herself to the Grave without one sigh of regret. . . She lay, . . . her lips still murmuring to him words of comfort. (Lewis 393)

There is a contradiction between Ambrosio's reaction to Antonia's loss of innocence and the ideal type religious consciousness during the Inquisition, however. After he has raped 
Antonia, Ambrosio contemplates keeping her prisoner in the underground sepulcher because she is "ruined," even though St. Augustine wrote that pious virgins who are raped are not responsible for their loss of virginity. Augustine maintained chastity was a virtue of the mind and is lost by the intention of $\sin$, even if the sin is not performed (Russell 356). This will not posit a logic problem for this work because even though we will use the ideal type religious consciousness to supplement details of Ambrosio's consciousness, we will acknowledge his unique traits that Lewis has created.

Even though Lewis leaves physical clues for us to equate Antonia with the angelic, the divine, the innocent in the actual language of his text, more evidence exists in Antonia's actions and the actions of those around her. For example, we are twice told of Antonia's fate: once in Lorenzo's dream mentioned above, and again by a Gypsy fortuneteller. Thus, we know she will be sacrificed, equating her with the innocence of the sacrificial lamb. Her innocence is further stressed by Lewis's revelation that her mother censors the Bible for her. The Bible gives "first alarm to the still sleeping passions," and "the annals of a Brothel would scarcely furnish a greater choice of indecent expressions," Lewis writes (259). Elvira, Antonia's mother, has two resolutions regarding the Bible and Antonia: that Antonia should not read it until she was old enough to "feel its beauties" and to profit by its morality, and that it should be copied by Elvira's hand and all improper passages altered or omitted" (259). Like Adam and Eve, Antonia is completely innocent until her tempter succeeds, and Ambrosio rapes her in the sepulcher.

Along these lines, it is the divineness of Antonia's purity that attracts Ambrosio, and Antonia as a "temptation" to sin is strong for him: when he first meets her, "The melody of her voice, of that voice to which no Man ever listened without interest, 
immediately caught Ambrosio's attention. ... Still her countenance was so sweet, so innocent, so heavenly, as might have charmed an heart less susceptible, than that which panted in the Abbott's breast" (240). Antonia's patron saint, Saint Rosalia, a descendant of Charlemagne, is a symbol of innocence herself: While a youth, she gave herself and her life completely to God, deciding to live her life in a cave to escape the attraction of worldly pleasures. On the walls, she wrote, "I, Rosalia, daughter of Sinibald, Lord of Roses and Quisquina, have taken the resolution to live in this cave for the love of my Lord, Jesus Christ" ("St. Rosalia," par. 1). She remained there entirely hidden from the world and died alone in 1160. Antonia's mother, Elvira, struggles to protect her daughter from Ambrosio; Antonia, in her innocence, is unable to discern Ambrosio's true designs, or is too innocent to believe them, even after Ambrosio has assaulted her and been discovered by her mother.

Antonia's character-symbol may be read as representing the innocence of humankind before the Fall. Ambrosio's fate is determined in direct correlation to his reaction to his power over Antonia, and because he misuses her, she becomes the instrument by which his fate is determined; his pollution of her innocence, symbolic of the innocence of man before the fall, leads directly to Ambrosio's doom. In addition, even though Ambrosio himself sees Antonia as innocence and purity (and this is what attracts him to her; throughout the text, Ambrosio pollutes the innocent-divine), he also sees her as a siren that brings about his demise, much as Adam blamed Eve for his own transgression, as discussed earlier in this chapter. Ambrosio's view of Antonia as siren is complete after he has raped her in the underground sepulcher of the Cathedral of St. Clair: 
And who am I to thank for this? What seduced me into crimes, whose bare resemblance makes me shudder? Fatal Witch! Was it not they beauty? Have you not plundered my soul into infamy? Have you not made me a perjured Hypocrite, a Ravisher, an Assassin! Nay, at this moment does not that angel look make me despair of God's forgiveness? Oh!, when I stand before his judgment-throne, that look will suffice to damn me! (Lewis 385)

Ambrosio's reaction certainly reminds us of the Malleus Maleficarum's position regarding women and their role in witcheraft and the fall of men. With these charactersymbols in mind as the foundation for this study, we move to the mouth of Ambrosio's phenomenological path to damnation with an examination of the sins that vault humankind-and Ambrosio--toward the Fall from Grace: the seven deadly sins. 


\section{Endnotes}

1 Superstition is a driving force behind Ambrosio's reaction to the symbols, events, environments, and people he encounters in his fictive Lifeworld. "The word 'superstition' asks to be understood in a variety of ways in the novel," Emma McEvoy writes (Lewis xxix).

2 See also Caesarius of Arles, in "An Admonition to Those Who Not Only Pay Attention to Omens, but What is Worse, Consult Seers, Soothsayers, and FortuneTellers in the Manner of Pagans" (ca. 530). He maintains that the Devil cannot injure the faithful unless he receives his power from God. "I beseech you to consider this, brethren. If the demons did not dare to enter swine without receiving the Lord's permission, who would be so perfidious as to believe they can harm good Christians in any way unless God allows it in His providence? God permits this for two reasons: either to try us, if we are good, or to punish us, if we are sinners" (49). 


\section{CHAPTER III: AT THE MOUTH OF THE PATH TO SUBJECTIVE SIN: THE SEVEN DEADLY SINS}

"Such evil could not occur unless someone caused it. But if you ask who that someone is, it is impossible to say. For there is no single cause of evil; rather, everyone who does evil is the cause of his own evildoing. If you doubt this, recall what I said earlier: Evil deeds are punished by the justice of God. They would not be punished justly if they had not been performed voluntarily." (Augustine, On Free Choice of the Will 1)

To this point, we have examined Original sin, or what Ricoeur terms "objective" sin, which comprises the foundation of sin for all humankind. Original sin is objective because according to Christian religious doctrine, all of humankind became unclean after the sin of Adam and Eve: "When Adam sinned we all sinned in him, not because we ourselves, who did not yet exist, sinned, but because we were to be born from him: it was then that the necessity was created that when we came to be we should sin, because 'through the sin of one disobedient man many were made sinners," Anselm writes (367). Objective sin, born in the Fall of Man and evidenced in Ambrosio's relationship to other character-symbols in The Monk, stands at the opening of Ambrosio's phenomenological path to damnation; it sets him up, if you will, for his own fall because he has inherited the propensity to sin from Adam and Eve. At some point, however, Ambrosio must transgress past the point of objective sin and begin his progression down the path by moving into acts of subjective $\sin$, or $\sin$ for which he alone is responsible. ${ }^{1}$ In addition, the sins that condemn him must be of such magnitude that he believes he cannot be forgiven of them. Lewis gives us a glimpse into the state of Ambrosio's conscience-a conscience reflective of Ricoeur's concept of the "servile will," or a captive free will 
caught in the juxtaposition between God's law and the physical experiences of the flesh - at the end of the text when his narrator states, "While Reason forced him to acknowledge a God's existence, Conscience made him doubt the infinity of his goodness. He disbelieved, that a Sinner like him could find mercy" (Lewis 426). While Ambrosio's conscience may seem flawed when compared with the ideal-type religious consciousness, it is these flaws that catapult him down the phenomenological path to damnation. For this work, examining the ideal type religious consciousness in light of its knowledge of the Seven Deadly Sins and their ramifications alongside Ambrosio's guilt of many of these sins will enlighten the first step Ambrosio takes down the path to self-damnation.

The Seven Deadly Sins in Gothic Literature, Religious Doctrine, and the Ideal-Type Religious Consciousness

Six things the Lord hates, Seven things are detestable to him: A proud eye, a false tongue, / Hands that shed innocent blood, /A heart that forges thoughts of mischief/And feet that run swiftly to do evil,/A false witness telling a pack of lies, / And one who stirs up quarrels between brothers. (Douay-Rheims The Holy Bible Proverbs 6:16-19)

The Seven Deadly Sins represent fault in excess, and the gothic is known for its examination of excess. We see many of the Seven Deadly Sins result in fates of characters such as the mariner in "The Rime of the Ancient Mariner" (1798), Victor Frankenstein in Mary Shelley's Frankenstein (1818), Dr. Henry Jekyll in The Strange Case of Dr. Jekyll and Mr. Hyde (1886), Ayesha in H. Rider Haggard's She (1887), Lady Audley in Lady Audley's Secret (1862), and Dr. Moreau from The Island of Dr. Moreau (1896). However, the Seven Deadly Sins were components of a rich religious history before they appeared in gothic literature. They first appear in the Douay-Rheims The Holy Bible as quoted above. In addition, the Seven Deadly Sins are reaffirmed through 
the Ten Commandments of the Old Testament, such as, "Thou shalt not kill," (DouayRheims The Holy Bible, Exodus 20:13) and "Thou shalt not bear false witness against thy neighbor" (Exodus 20:16). In philosophical religious discourse, fourth-century monastic Evagrius first compiled a list of eight offenses and wicked human passions, in order from worst to least offensive: Gluttony, lust, avarice (covetousness), sadness, anger, acedia (spiritual Sloth), vainglory, and pride (A Brief History, par. 2). Pope Gregory the Great, in the late sixth century, reduced the list to seven sins and included vainglory with pride, acedia with sadness (later termed "Sloth"), as well as added Envy, leaving the familiar list known today: pride, anger, Envy, greed, Sloth (spiritual lethargy coupled with sadness), Gluttony, and lust. Gregory ranked the sins in order from most- to leastoffensive against love: pride, Envy, anger, sadness, avarice, Gluttony, and lust, and maintained that pride breeds all of the other sins, and thus is the most serious (Kastenbaum, par. 2). St. Thomas Aquinas, in Summa Theologica, maintained that pride is rebellion against God's authority (Schimmel 25).

The Fourth Lateran Council, in 1214, moved to educate the laity about the Seven Deadly Sins and established the practice of annual confession for everyone, but for priests to carry out their missions, they had to be educated to counsel their penitents and people had to recognize and recall their sins (University, par. 6). Bishops issued Constitutions listing material clergy were to learn and teach, and these often included information regarding the Seven Deadly Sins (par. 7). To aid understanding of the Seven Deadly Sins for often-illiterate laypeople, the sins were often depicted on wall paintings in churches. Note, for example, the church wall painting to the right which depicts the Seven Deadly Sins. The University of Leicester, under the direction of Dr. Phillip 
Lindley, has established a web

resource dedicated to the study of

the Seven Deadly Sins and the

seven corporal works of mercy in

church wall paintings in the

Medieval Era, although many of

the works discussed are located in

Britain as opposed to Italy. Many

British church paintings were

whitewashed, however, first under

Henry VIII's Dissolution of the

Monasteries and then by Puritans
Figure 3: Medieval church wall painting

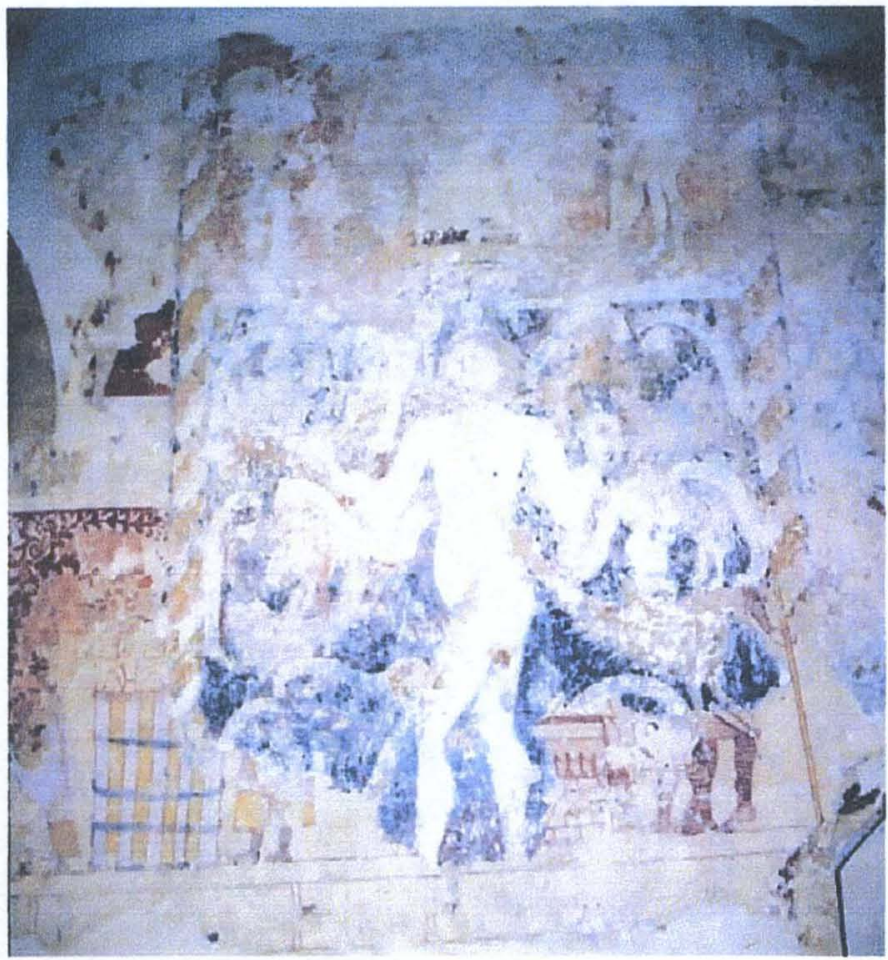

during the Civil War. According to Lindley, the earliest surviving wall paintings of the Seven Deadly Sins date from the first half of the fourteenth century. The illustration above is a snapshot from a painting, the "Weighing of Souls," at South Leigh, Oxfordshire, and the Seven Deadly Sins are at the center of the painting. A number of scrolls project from the body of a naked male figure; some of these scrolls have lettering still visible. The central figure represents the primary cardinal sin, Pride, with the other six deadly sins arranged around it. Gluttony is at the top left, drinking from a bowl offered by the devil. Below it is avarice, receiving bags of money. Lust is at the bottom, with two people being encouraged by the devil to engage in it. Envy is at the top, and some type of beast with vicious teeth is holding a depiction of it. Wrath, below Envy, is illustrated by a confrontation between a man with a dagger and a devil. Sloth was surely 
depicted as well, but was obliterated by the removal of some plaster from the wall (Medieval Painting). In most such paintings, each of the sins was depicted with a specific punishment in Hell, reminiscent of punishments in "The Inferno" of Dante's The Divine Comedy: pride, broken on the wheel; Envy, put in freezing water; anger, dismembered alive; Sloth, thrown in snake pits; greed, put in cauldrons of boiling oil; Gluttony, forced to eat rats, toads, and snakes; and lust, smothered in fire and brimstone (A Brief History, par. 7).

A similar scene is shown in the Cathedral of St. Cecelia in Albi, France. The mural of "The Last Judgment" covers two sides of a wall. It was painted by unknown FrancoFlemish artists (contemporaries of Hieronymus Bosch) and is considered one of the most important works of art for the Late Middle Ages ("Cathedral of. St. Figure 4: "The Last Judgment," Cathedral of St. Cecelia

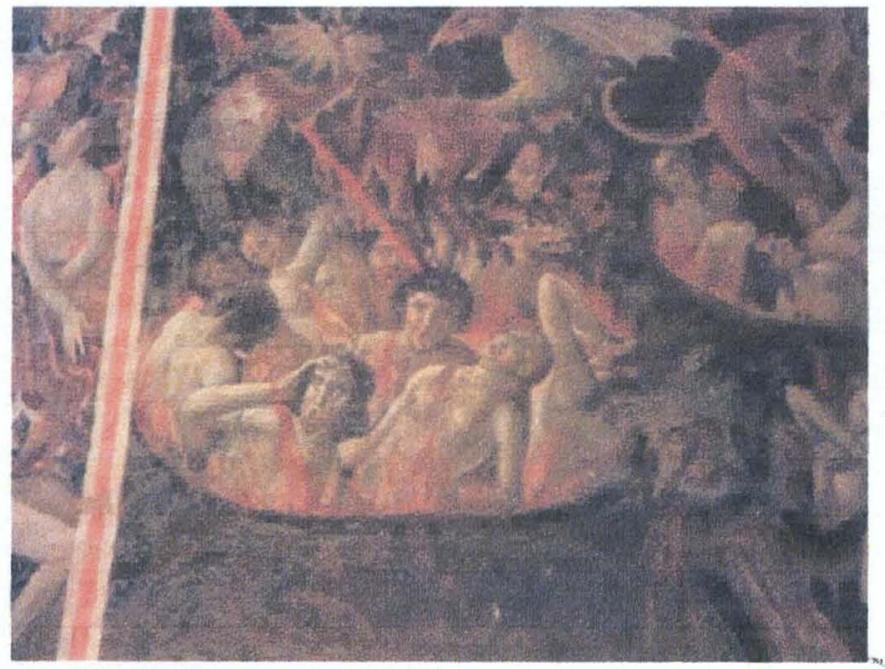
Cecelia, Albi," par. 7). The work shows the blessed on the left and the damned on the right, in contradiction to Jesus' account of separating the good on the right and wicked on the left in Matthew 25 (Douay-Rheims The Holy Bible). The painting is organized around the theme of the Seven Deadly Sins with suffering humans and demons in its vision of the underworld; they depict (left to right) Pride, Envy, Wrath, Greed, Gluttony, and Lust ("Cathedral of St. Cecelia, Albi," par. 8). Religious leaders wanted to ensure laypeople knew the sins and their dangers, and because many people were illiterate, art 
became a medium through which to communicate this vital information. Obviously the ideal-type religious consciousness, which we have equated with Ambrosio's consciousness, would have known of the dangers of these sins, not only from religious leaders and artwork, but from the Bible itself.

Why were the Seven Deadly Sins known as "capital" sins? Solomon Schimmel explains:

Pride, which for Aquinas is contempt for God and the refusal to obey Him, is the "head" or "root" of all sin. A sin is also "capital" if it is the reason for committing other sins. Greed is a capital sin because we steal, cheat, and lie to satisfy it. Sloth is a capital sin because we ignore the dictates of charity out of our apathy to spiritual matters. Envy will induce us to harm others. A sin is also called capital if it enables us to commit many other sins. The money we accumulate through our greed empowers us to be gluttons or lechers, and to do other evil things. (25-6).

In other words, Christian religious leaders believed the Seven Deadly Sins led to capital offenses and left the soul in peril after the body perished. "A capital vice is one from which other vices arise, chiefly by being their final cause, which origin is formal, as stated above. Wherefore a capital vice is not only the principle of others, but is also their director and, in a way, their leader: because the art or habit, to which the end belongs, is always the principle and the commander in matters concerning the means. Hence Gregory (Moral. Xxxi, 17) compares these capital vices to the "leaders of an army," Aquinas writes in Summa Theologica, "Question 84" (176).

In addition-and leading us toward Ricoeur's idea of the subjective pole of $\sin -$ religious leaders such as Aquinas examined the role of the will in the Seven Deadly Sins. Schimmel, in The Seven Deadly Sins, writes that in Christianity, Jesus emphasizes faith, ethical concerns, and inner states and intentions. In Matthew 5:21-22, 27-28, Jesus says: "You have heard that it was said to them of old: Thou shalt not commit adultery. But I 
say to you that whosoever shall look on a woman to lust after her hath already committed adultery with her in his heart" (Douay-Rheims The Holy Bible). Jesus's teachings follow the lines of Paul, who views the struggle against sin as one of will and temptation: "The body is the source of sin and we are impotent to overcome its temptations by exertion of our will alone. We must rely on faith in Christ as the means for freeing ourselves from sin" (Schimmel 15).

We depart a bit from Ricoeur by maintaining that indulgence in the Seven Deadly Sins (particularly for Ambrosio in The Monk) is the departure point for the subjective pole of sin-consciousness. Ricoeur maintains that the "subjective" pole of the consciousness of sin is actually the changing of fear and anguish rising from the consciousness of defilement to the consciousness of $\sin (63)$, after which a new quality of anguish results; the movement from consciousness of defilement to consciousness of sin is integral to the movement from the objective pole to the subjective pole of sinconsciousness. Although it is impossible to point to a specific event and maintain it is the point where the subjective pole of sin-consciousness begins, it is possible to locate in the history of sin the point where individual will begins to be emphasized, and that is with the concept of the Seven Deadly Sins. Although we are all guilty of Original sin, as Anselm maintains, we have no control over that burden. This departure point also illustrates the beginning of the "unhappy conscience" for Ambrosio, as we shall see evidenced later in this work; it is after his indulgence in many of the Seven Deadly Sins that we see his conscience become active as it strives to present his actual self to his consciousness, but his falsely-constituted self, constantly reinterpreted and shaped by the 
people, events, and environments around him, rejects these assertions and continues to exist in what philosopher Jean Paul Sartre terms "bad faith."

Ambrosio and the Seven Deadly Sins, False Intersubjective Constitution, and Conscience

He was no sooner alone, than He gave loose to the indulgence of his vanity. When He remembered the Enthusiasm which his discourse had excited, his heart swelled with rapture, and his imagination presented him with splendid visions of aggrandizement. (Lewis 39).

At the end of The Monk, when the shocked reader realizes Satan has manipulated Ambrosio throughout the entire text, Satan tells Ambrosio what attracted him into Ambrosio's life: the sin of Pride, the most capital of all the Seven Deadly Sins. "Know, vain Main! That I long have marked you for my prey: I watched the movements of your heart; I saw that you were virtuous from vanity, not principle, and I seized the fit moment of seduction," Satan exclaims (440), and Jesus teaches that sins come from the heart in Matthew 15: 19-20: "For out of the heart proceed evil thoughts, murders, adulteries, fornications, thefts, false witness, blasphemies: These are the things which defile a man. ..." (Douay-Rheims The Holy Bible). We see the symbolism of Ambrosio's capital sin of Pride when Lorenzo dreams of Antonia: Her lover is about to clasp her in his arms, and an Unknown rushes between them, gigantic in form with eyes "fierce and terrible," with the words "Pride! Lust! Inhumanity!" written upon his forehead (28). The Unknown is in the image of Satan, but will come to Antonia in the form of Ambrosio. In fact, we first see Ambrosio existing in "bad faith" after he returns from his public speech where he displays complete humility until he returns to his room where "Pride told him loudly that He was superior to the rest of his fellow Creatures" (40). Lewis is not alone in his exploration of the ramifications of the capital sin of 
Pride-it is the fatal flaw of many characters in gothic fiction. In Horace Walpole's The Castle of Otranto (1762), an ancient prophecy casts doubt on Manfred and his lineage as the rightful owners of Otranto, predicting "that the castle and lordship of Otranto should pass from the present family, whenever the real owner should be grown too large to inhabit it" (Walpole 17), and in his struggle to maintain ownership of Otranto and his significant standing in the community, Manfred seals the doom of himself and his heirs. We also see Victor Frankenstein hurtle his self into an abyss of misery in Mary Shelley's Frankenstein (1818) with his pride reminiscent of Satan in Paradise Lost: "A new species would bless me as its creator and source; many happy and excellent natures would owe their being to me. No father could claim the gratitude of his child so completely as I should deserve theirs" (Shelley 32). Schimmel relates the foundation of the sin of Pride to Satan in Milton's "Paradise Lost," where Milton presents "the inner life of pride, the thoughts and attitudes of the proud sinner" (35). "One who brings/ A mind not to be changed by Place or Time / The mind is its own place, and in it self/ Can make a Heaven of Hell, a Hell of Heaven," Satan says (Milton, lines 249-263). Like Satan, Ambrosio seems to be unaware of his Pride. Schimmel writes:

Pride is unique among the Seven Deadly Sins in that we are frequently unaware of our ignorance, whereas we tend to know when we are angry, greedy, gluttonous, and so on. Moreover, unlike the other six sins, when our pride is pointed out to us we often do not even realize it is a vice. This is because it is difficult for us to admit that we are of less worth than we imagine ourselves to be, and because our culture values high self-esteem and fails to appreciate humility or even modesty. (36)

With this in mind, how was the sin of Pride viewed in Ambrosio's time, which we have set in the early seventeenth century? St. Thomas Aquinas, with whose works the ideal-type religious consciousness would have been familiar, writes in Summa 
Theologica "Question 84" that Pride, or the "inordinate desire to excel," is the beginning of every $\sin (175)$. Pride also represents a turning away from God: "Apostasy from God is stated to be the beginning of pride, in so far as it denotes a turning away from God, because from the fact that man wishes not to be subject to God, it follows that he desires inordinately his own excellence in temporal things," Aquinas writes (175). Pride makes humankind despise the divine law which hinders him from sinning, Aquinas writes, and pride destroys every virtue ("Question 162"). The proud person does not subject his will to God, and thus knows nothing of truth, Aquinas writes, and quotes Pope Gregory the Great: "The proud, although certain truths be conveyed to their understanding, cannot realize their sweetness: and if they know of them they cannot relish them" (par. 29, 30). This inability to recognize Truth will be integral to Ambrosio's false intersubjective constitution of his self, as we shall examine later in this work.

Aquinas also mentions degrees of humility and how they are diametrically opposed to traits of Pride, and his writings especially reflect Ambrosio's sin of Pride. For example, the fifth degree of humility is "to do nothing but to what one is exhorted by the common rule of the monastery," which is opposed to "singularity," whereby a man wishes to seem more holy than others (Summa 176); in The Monk, we see Ambrosio exclaim, "Religion cannot boast Ambrosio's equal!" (Lewis 40). Aquinas writes the sixth degree of humility is "to believe and acknowledge oneself viler than all," which is opposed to arrogance, whereby "a man sets himself above others" (176); in The Monk, we see Ambrosio commit this very act through the preceding quote. The seventh degree of humility is "to think oneself worthless and unprofitable for all purposes," which is opposed to "presumption, whereby a man thinks himself capable of things that are above 
him; in The Monk, we see Ambrosio, as he is lusting after the portrait of the Virgin Mary in his room, remark: "Temptation, did I say? To me it would be none" (Lewis 41). The last degree of humility is "fear of God," Aquinas writes, which is opposed to the "habit of sinning, which implies contempt of God"; once Ambrosio has tasted the pleasures of the flesh, he willingly continues to indulge his appetite. Aquinas adds that some are even proud of their humility. Aquinas quotes Boethius: "While all vices flee from God, pride alone withstands God" (176). Aquinas anticipates the plot of The Monk when he writes that "God punishes certain men by allowing them to fall into sins of the flesh, which though they be less grievous are more evidently shameful," and quotes Isidore: "For he who is in the clutches of pride and feels it not, falls into the lusts of the flesh, that being thus humbled he may rise from his abasement" (177). This lends an interesting twist to Ambrosio's fate in the novel; even though a first reading reveals Satan to be a primary component in Ambrosio's downfall, it is possible God has allowed him to do so to lead Ambrosio back into his fold. We will explore this more as we progress.

In the meantime, there is little doubt that Ambrosio's sin of Pride leads him to commit other sins and is thus a capital sin. At the end of the text, Satan tells Ambrosio what led him to the monk:

Know, vain Man! That I long have marked you for my prey: I watched the movements of your heart; I saw that you were virtuous from vanity, not principle, and I seized the fit moment of seduction. I observed your blind idolatry of the Madona's picture. I bad a subordinate but crafty spirit assume a similar form, and you eagerly yielded to the blandishments of Matilda. Your pride was gratified by her flattery; Your lust only needed an opportunity to break forth; You ran into the snare blindly, and scrupled not to commit a crime, which you blamed in another with unfeeling severity.... Scarcely could I propose crimes so quick as you performed them. . . Believe you, that your secret thoughts escaped me? No, no, I read them all! You trusted that you should still have time for repentance. I saw your artifice, knew its falsity, and rejoiced in deceiving the deceiver! (Lewis 440441) 
Unless one surmises Satan is the king of deception and may very well be lying to Ambrosio - and remember, it is God who is absent in this text, much as Ricoeur maintains God absents himself from the sinner as the "Wholly Other," although, as we shall see in Chapter 6 of this work, it is Ambrosio who absents God from his consciousness as the "Mythological Other"- it is Pride that draws Satan into Ambrosio's life. In fact, after Ambrosio rebukes the Spirits of Darkness in a fit of Pride by saying, "Fear not, Ambrosio! Take confidence in the strength of your virtue. Enter boldly into a world, to whose failings you are superior; Reflect that you are now exempted from Humanity's defects, and defy all the arts of the Spirits of Darkness. They shall know you for what you are!" (Lewis 41), Matilda-in the form of Rosario-knocks softly three times on Ambrosio's chamber door. ${ }^{2}$ It is as if Ambrosio has literally invited the Spirits of Darkness into his life while venting his Pride.

According to Ricoeur, confession is integral to the religious consciousness, and yet Ambrosio never confesses his crimes in The Monk because he is frightened of losing his reputation, also a mark of Pride. This leads Ambrosio to further crimes, or sins. Ambrosio allows Matilda to stay at the monastery because "to vanquish temptation was an infinitely greater merit than to avoid it" (Lewis 83). After his first tryst with Matilda, "He shuddered at reflecting, that a trifling indiscretion on his part, or on Matilda's, would overturn that fabric of reputation which it had cost him thirty years to erect, and render him the abhorrence of that People of whom He was then the Idol" (227), and so he resolves to keep Matilda as his mistress in part to avoid any risk to his reputation. After Ambrosio rapes Antonia, he exclaims, "You shall not from hence to tell Madrid that I am a Villain; that my conscience is loaded with sins, which make me despair of Heaven's 
pardon" (385). Ambrosio has no intention of murdering Elvira, Antonia's mother, reminiscent of the literary trope of the child murdering the parent in Sophocles's "Oedipus Rex," until Elvira threatens to expose his transgressions to the public: "Your Iniquity shall be unveiled to the public eye: all Madrid shall shudder at your perfidy, your hypocrisy and incontinence" (302). Ambrosio at this point still plans to run from the room and return to the Abby before his guilt can be discovered, but Elvira detains him by the arm:

Ambrosio struggled in vain to disengage himself. Elvira quitted not her hold, but redoubled her cries for succour. The Friar's danger grew more urgent. He expected every moment to hear people assembling at her voice; And worked up to madness by the approach of ruin, He adopted a resolution equally desperate and savage. Turning round suddenly, with one hand He grasped Elvira's throat so as to prevent her continuing her clamour, and with the other, dashing her violently upon the ground, He dragged her towards the Bed. Confused by this sudden attack, She scarcely had power to strive at forcing herself from his grasp: While the Monk, snatching the pillow from beneath her daughter's head, covering with it Elvira's face, and pressing his knee upon her stomach with all his strength, endeavoured to put an end to her existence. He succeeded but too well. (303-304)

After murdering Elvira, Ambrosio tidies the chamber by replacing the pillow upon the bed and gathering his possessions. We find as time passes, Ambrosio's guilt is assuaged by the non-detection of his crimes: "He began to resume his spirits; and as his fears of detection died away, He paid less attention to the reproaches of remorse" (305). Here Ambrosio's self denies the truth his conscience presents to him, but we will discuss that further into this work as we progress down the actual steps to his phenomenological path to damnation. For the mouth to Ambrosio's path to damnation-the Seven Deadly Sinsan examination of Pride and the other capital sins and how they lead Ambrosio to further sins is sufficient. However, it is important to note that Ambrosio's pride may not be ingrained in him from birth, but may be the result of his false intersubjective constitution, 
or incessant shaping of his self, with the characters and events that surround him in the text.

When we are first introduced to the monk, it is through an event by which he falsely intersubjectively constitutes his self. The text opens with an air of excitement as people supposedly await Ambrosio's arrival; he is scheduled to address the crowd and is known for his excellent oratory skills, and yet Lewis's narrator warns us that the motives for the crowd's gathering are not what they seem or should be: "The Audience now assembled in the Capuchin Church was collected by various causes, but all of them were foreign to the ostensible motive ... The only persons truly anxious to hear the Preacher were a few antiquated devotees, and half a dozen rival Orators, determined to find fault with and ridicule the discourse" (7). Ambrosio's thoughts when he returns to his chamber after successfully delivering his address to the crowd illustrate a binary opposition between his interior world and the physical world: "When He remembered the Enthusiasm which his discourse had excited, his heart swelled with rapture, and his imagination presented him with splendid visions of aggrandizement. He looked round him with exultation, and Pride told him loudly, that He was superior to the rest of his fellow-Creatures" (39-40). In addition, Ambrosio's emotions are contrary to the edict of the Order of the Capuchins, which was a selfiess aim to help the poor and helpless; it is possible Lewis had this in mind when he crafted the setting of The Monk. As Schimmel writes, it is difficult for us to admit we are of less worth than we imagine ourselves to be (36), and a significant part of Ambrosio's mental self-worth comes from those around him. The Prioress, for example, is horrified when she hears Agnes is pregnant and has obviously broken her vow of chastity, but she is even more horrified that Ambrosio 
discovered this: "What! Such a crime committed in her convent, and made known to Ambrosio, the Idol of Madrid, to the Man whom She was most anxious to impress with the opinion of the strictness and regularity of her House?" (Lewis 48).

Here we shall digress a bit from Ricoeur and follow an idea of philosopher Jean Paul Sartre, whose philosophy of "bad faith" haunts Ambrosio's self and his conscience during his movement down the phenomenological path to damnation. We live in bad faith when we "act and live in self-deception or inauthenticity," according to Sartre (Moore 172). Notice that Ambrosio willfully lives in bad faith throughout the text: he believes himself to be the most "godlike" of humans, yet he realizes the weight of his crimes and continues to pursue them, relying upon his belief that he will seek God's forgiveness before he dies, and he continues to present himself to the public as a pillar of moral superiority. This bad faith, coupled with his false intersubjective constitution, or defining of his self in relation to the characters, events, and settings that surround him in his fictive Lifeworld, helps him paint a false image of his self to his self and his conscience, and is the beginning of the "unhappy conscience." The unhappy conscience knows the "true" self and acts as a mirror for the self to realize this truth; however, at this point, Ambrosio's self ignores his conscience, resulting in the "unhappy conscience." The conscience realizes the self is "short" of the mark of goodness as set by God, as Ricoeur maintains, but it also realizes there is hope of redemption. As we progress down Ambrosio's phenomenological path to damnation, we will see his conscience progress from the "unhappy conscience" to what we shall term the "condemned conscience," when Ambrosio's self believes there is no hope of redemption for his sins, and on to the "accused" and "condemned" consciences. As Lewis's narrator tells us, "Ambrosio was 
yet to learn, that to an heart unacquainted with her, Vice is ever more dangerous when lurking behind the Mask of Virtue" (84).

Ambrosio and Lust

Drunk with desire, He pressed his lips to those which sought them: His kisses vied with Matilda's in warmth and passion. He clasped her rapturously in his arms; He forgot his vows, his sanctity, and his fame: He remembered nothing but the pleasure and opportunity. 'Ambrosio! Oh! My Ambrosio!' sighed Matilda. 'Thine, ever thine!' murmured the Friar, and sank upon her bosom (Lewis 90-91).

The Bible does not condemn sexual intercourse between a married man and woman; "sexual intercourse between husband and wife is obligatory and should be enjoyed by both," Schimmel writes (113), and Aquinas writes that sexual intercourse is necessary for continuation of the human species ("Question 153," par. 13). For example, the Bible's "The Song of Solomon," referred to as the "Canticle of Canticles" in the Douay-Rheims The Holy Bible, is a collection of love poems celebrating sexual attraction and yearning. "How beautiful are thy breasts, my sister, my spouse! thy breasts are more beautiful than wine, and the sweet smell of they ointments above all aromatical spices. . . My beloved put his hand through the key hole, and my bowels were moved at his touch" (Douay-Rheims The Holy Bible, Canticle of Canticles 4:10, 5:4). However, Ambrosio, who would have possessed the ideal type religious consciousness, had taken vows of chastity and would have been aware of the dangers the Bible and religious scholars such as Aquinas express regarding unbridled lust and adultery, a direct violation of the Ten Commandments. For example, in the Bible, King David entertains lustful thoughts regarding Bathsheba, the wife of Uriah. To secure Bathsheba as his bride, David sends Uriah to the front lines of the army, where David knows Uriah will be killed. After 
Uriah's death, David marries Bathsheba and they have a son, whose life God takes in retribution for David's sin. The Bible also contains the story of the rape of Thamar ("Tamar" in the King James version of the Bible, but "Thamar" in the Douay-Rheims The Holy Bible) by her paternal half-brother, Amnon. Amnon became infatuated with her but could not have her, so he feigned illness and asked David to send her to serve his meals. David does, and Amnon rapes her, then despises her and sends her away (DouayRheims The Holy Bible, 2 Kings 13 ) in an emotional response akin to Ambrosio's reactions after he has sexual relations with women in The Monk. Schimmel writes that Amnon's love for Thamar is "nothing more than a desire for her body-not her person," because after he rapes her, he forces her to leave him in shame (120). Schimmel warns of the power of lust and its ramifications:

David was a religious man who understood the gravity of adultery. When not overcome by sexual passion he had a passion for justice. Did he feel no guilt as he lay with Bathsheba while her husband Uriah was jeopardizing his life to defend the kingdom? David, a brilliant and courageous leader, acted foolishly and cowardly, risking power and prestige, in order to satisfy his sexual urge. Lust is more powerful than shame, guilt, fear, prudence, and gratitude. When we succumb to lust we can be blinded to our most blatant crimes, as David is when he condemns the evil of the rich man in Nathan's parable but remains oblivious to worse evil in himself. He doesn't grasp the analogy of the parable to his own transparent behavior. Unrestrained sexual desire can corrupt the best of men and lead to irrational, unethical behavior. ... Although sexual passion is a powerful force, we are not absolved of responsibility for the evils we commit when we fail to control it. (Schimmel 116)

Schimmel also explains the Christian view that humankind, created in the image of God "who has implanted in us a soul that shares elements of the divine," should remain free of preoccupations with the body (146).

In addition, some religious scholars such as Aquinas maintain that the pursuit of pleasure reflects a weakness of reason and the will, and not using one's reason is contrary 
to the will of God (Schimmel 146). Aquinas takes an Aristotelian approach to the examination of Lust as one of the Seven Deadly Sins, and his writings would have been well-known to the ideal type religious consciousness of Ambrosio's period. "Now lust consists essentially in exceeding the order and mode of reason in the matter of venereal acts. Wherefore without any doubt lust is a sin," Aquinas writes ("Question 153," par. 22). Aquinas also warns the lustful about the consequences of their actions by quoting Augustine: "To the lustful it is said (De Vera Relig. iii): 'He that soweth in the flesh, of the flesh shall reap corruption"' (par. 4)

Aquinas affirms to several reasons lust is a capital vice. "A capital vice is one that has a very desirable end, so that through desire for that end, a man proceeds to commit many sins, all of which are said to arise from that vice as from a principal vice. Now the end of lust is venereal pleasure, which is very great. Wherefore this pleasure is very desirable as regards the sensitive appetite, both on account of the intensity of the pleasure, and because such like concupiscence is connatural to man. Therefore it is evident that lust is a capital vice," Aquinas writes (par. 30). Aquinas quotes Augustine: "I consider nothing so casts down the manly mind from its height as the fondling of a woman, and those bodily contacts" (par. 8). However, it is more than just a surrendering of the reason and will to the pleasures of the flesh that makes Lust such a dangerous sin:

On the part of the will there results a twofold inordinate act. One is the desire for the end, to which we refer 'self-love,' which regards the pleasure which a man desires inordinately, while on the other hand there is 'hatred of God,' by reason of His forbidding the desired pleasure. The other act is the desire for the things directed to the end. With regard to this there is 'love of this world,' whose pleasures a man desires to enjoy, while on the other hand there is 'despair of a future world,' because through being held back by carnal pleasures he cares not to obtain spiritual pleasures, since they are distasteful to him. (Aquinas, "Question 153," par. 41). 
This is reminiscent of Aquinas's idea that we are too much of this world, and we see Ambrosio address this idea as he examines an inscription on the Grotto in the Abbey Garden: "Man was born for society. However little He may be attached to the World, $\mathrm{He}$ never can wholly forget it, or bear to be wholly forgotten by it" (Lewis 53). We also see Ambrosio turn away from the spiritual when he is exposed to the desires of the feminine, especially when he becomes "willfully blind" to the dangers of exposing himself to Antonia (256); "He was not unconscious, that his attempts were highly criminal: He saw clearly the baseness of seducing the innocent Girl: But his passion was too violent to permit his abandoning his design. He resolved to pursue it, let the consequences be what they might" (257). Ambrosio, at this point, has become too much of this world; his primary goal is to secure pleasures of the flesh, in direct opposition to building his spiritual relationship with God.

An even more dangerous aspect of lust exists, however. Aquinas quotes the Apostle Paul, who remarks in 1 Corinthians 6:20 that we "are bought with a great price," and that we should glorify and bear God in our bodies. "Wherefore by inordinately using the body through lust a man wrongs God Who is the Supreme Lord of our body," Aquinas writes ("Question 153, par. 24). "Hence Augustine says (De Decem. Chord. 10): 'God Who thus governs His servants for their good, not for His, made this order and commandment, lest unlawful pleasures should destroy His temple which thou hast begun to be" (par. 24). For centuries our bodies have been thought of as God's temple, and lust de-sanctifies this holy space. We see this thought evidenced when Ambrosio confronts Anges with the note that falls from her garment, a note that reveals her pregnancy: "You have abandoned yourself to a Seducer's lust; You have defiled the sacred habit by your 
impurity; and still dare you think yourself deserving my compassion?" Ambrosio thunders to her (Lewis 46). After he has sexual intercourse with Matilda, we experience Ambrosio's defilement--a step on his internal path to damnation--through his words:

"What can now be done? What atonement can purchase the pardon of my crime?

Wretched Matilda, you have destroyed my quiet forever!" (Lewis 223). This is certainly a step toward the destruction of Ambrosio's mental "temple," his view of his own body as a holy, sacred space.

In addition, Ambrosio's Lust often corrupts the physical holy space throughout Lewis's text, illustrating its permeable boundaries; it also defiles religious iconography in Lewis's fictive world. Ambrosio's first feel for Lust, as far as the reader knows, comes when he is discoursing regarding the portrait of the Virgin Mary in his room at the Abbey, after his triumphant (or what he perceives as triumphant-there is a difference, as we have discussed) oratory near the beginning of Lewis's text. Lewis's narrator, who alone shares a view of Ambrosio's inner Lifeworld, or fictive world in which he exists, states:

'What Beauty in that countenance?' He continued after a silence of some minutes; 'How graceful is the turn of that head! What sweetness, yet what majesty in her divine eyes! How softly her cheek reclines upon her hand! Can the Rose vie with the blush of that cheek? Can the Lily rival the whiteness of that hand? $\mathrm{Oh}$ ! if such a Creature existed, and existed but for me! Were I permitted to twine round my fingers those golden ringlets, and press with my lips the treasures of that snowy bosom! Should I not barter for a single embrace the reward of my sufferings for thirty years? Should I not abandon . . . Fool that I am! Whither do I suffer my admiration of this picture to hurry me? Away, impure ideas! Let me remember, that Woman is for ever lost to me. (40-1).

Aquinas writes that The Council of Trent, in declaring that all mortal sins must be confessed, makes special mention of those that are most secret, adding that they 
"sometimes more grievously wound the soul and are more dangerous than sins which are openly committed" ("Sin," par, 7)

Yet, as Aquinas and Augustine admit, Lust is difficult to repel, and we see this evidenced in Ambrosio's actions throughout the text, up to the point where he no longer struggles against it; as we progress, we will establish Ambrosio's mental transitions that comprise his phenomenological path to damnation. In the Abbey garden, a holy space we established as a metaphor for the Garden of Eden, we see Ambrosio flee from Lust and Temptation when he first realizes Rosario is Matilda. In an act of verbal symbolism that illustrates a mental step from the divine to the worldly, he tells Rosario, "I lay aside the Monk, and bid you consider me as no other than your Friend, your Father" (Lewis 57). After Rosario admits he is Matilda, Ambrosio flees toward the Abbey, but Matilda catches him; Ambrosio's shock robs him of speech. He later maintains he cannot allow Matilda to remain among the monks, disguised as Rosario; "The risque of your being discovered is too great, and I will not expose myself to so dangerous a temptation" (63). When Matilda threatens to kill herself and tears her habit, Ambrosio is first exposed to the physical temptation of Lust:

She had torn open her habit, and her bosom was half-exposed. The weapon's point rested upon her left breast: And Oh! that was such a breast! The Moon-beams darting full upon it, enabled the Monk to observe its dazzling whiteness. His eye dwelt with insatiable avidity upon the beauteous Orb. A sensation till then unknown filled his heart with a mixture of anxiety and delight: A raging fire shot through every limb; The blood boiled in his veins, and a thousand wild wishes bewildered his imagination. "Hold!" He cried in a hurried, faultering voice; "I can resist no longer! Stay, then, Enchantress; Stay for my destruction!" (65)

It is important to note here that Ambrosio's perception of this situation is the same as the reader's at this point; Matilda seems to be a virtuous young woman who only wants to be 
near Ambrosio because of his religious influence upon her. However, at some point in the novel, the reader's perception of events will become "Truth" while Ambrosio's will be false because of his false intersubjective constitution, or shaping and defining of his self, with his environment. We will establish this moment as we progress down the steps to his path to self-damnation in consciousness.

Further pollution of the holy space of the Abbey occurs even as Ambrosio is attempting to fight the temptation of the feminine in the guise of Matilda. Lewis's narrator remarks that Ambrosio is "conscious that prudence, religion, and propriety necessitated his obliging her to quit the Abbey: But on the other hand, such powerful reasons authorized her stay, that He was but too inclined to consent to her remaining" (66). Matilda's affections for him spring, in part, from his vanity; he is pleased that she has chosen him among all of Spain's "noble cavaliers" (66), further illustrating Aquinas's thought that all sins stem from the capital sin of Pride, as discussed earlier. Lust continues to rise in Ambrosio's bosom even as he is trying to fight the temptation of the feminine: "Had She been desirous to gain my affections, not my esteem, She would not have concealed from me her charms so carefully: At this very moment I have never seen her face: Yet certainly that face must be lovely, and her person beautiful, to judge by her . by what I have seen" (67). He is alarmed at these sentiments and begins to pray, asking the picture of the Virgin Mary for assistance with fighting his emotions; afterward, he sleeps, but is haunted by dreams:

Matilda stood before him in his dreams, and his eyes again dwelt upon her naked breast. She repeated her protestations of eternal love, threw her arms around his neck, and loaded him with kisses: He returned them; He clasped her passionately to his bosom, and ... the vision was dissolved. Sometimes his dreams presented the image of his favourite Madona, and He fancied that He was kneeling before her: As He offered up his vows to her, the eyes of the Figure 
seemed to beam on him with inexpressible sweetness. He pressed his lips to hers, and found them warm: the animated form started from the Canvas and embraced him affectionately, and his senses were unable to support delight so exquisite. Such were the scenes, on which his thoughts were employed while sleeping: His unsatisfied Desires placed before him the most lustful and provoking Images, and he rioted in joys till then unknown to him. (67)

One of the most grievous acts of pollution of the Holy Space occurs, however, when Ambrosio engages in sexual intercourse with Matilda in his chamber.

Aquinas writes that an even greater danger of Lust is that it breeds daughters such as "blindness of mind," which means simple understanding is impinged; "rashness," which denotes absence of counsel; "thoughtlessness," which implies not using proper judgment; and "inconstancy," whereby a man is hindered from doing what his reason orders to be done. All of these are contrary to reason, and are thus sins; all of these are born of the capital sin of Lust ("Question 153," par. 40). We see all of these evidenced in Ambrosio's actions throughout the text once he is guilty of Lust. For example, he murders Elvira in a sudden rush to protect himself, a moment of "rashness"; he secures Matilda's aid to secure a favor from Satan in a moment of "thoughtlessness"; he decides to keep Antonia secured in the underground sepulcher after he rapes her, a moment of "inconstancy"; and he suffers from "blindness of mind" after Matilda refuses to grant him sexual favors any longer: "Naturally addicted to the gratification of the senses, in the full vigour of manhood, and heat of blood, He had suffered his temperament to acquire such ascendency, that his lust was become madness" (380). We also see Ambrosio suffering from all of the daughters of Lust when he determines he will keep his relationship with Matilda:

He considered the pleasures of the former night to have been purchased at a very easy price by the sacrifice of innocence and honour. Their very rememberance filled his soul with ecstasy; He cursed his foolish vanity, which 
had induced him to waste in obscurity the bloom of life, ignorant of the blessings of Love and Woman. He determined at all events to continue his commerce with Matilda, and called every argument to his aid, which might confirm his resolution. ... By adhering strictly to every rule of his order save Chastity, He doubted not to retain the esteem of Men, and even the protection of heaven. He trusted easily to be forgiven so slight and natural a deviation from his vows: But He forgot that having pronounced those vows, Incontinence, in Lay-men the most venial of $e$ rrors, became in his person the most heinous of crimes. (227)

In addition, it is the sins of Pride and Lust that most lead to Ambrosio's false intersubjective constitution with the people, events, and environments in Lewis's fictive Lifeworld, and his false intersubjective constitution is a primary component that hurtles him down the steps to his interior damnation. This false intersubjective constitution, or shaping and defining of the self with the characters, events, and settings in the fictive Lifeworld of Ambrosio's existence, coupled with Sartre's concept of bad faith, leads Ambrosio to avoid confession of his sins, which, according to Ricoeur, is essential for the religious consciousness. As we mentioned above, Ambrosio refuses to confess, in part, because his Pride will not allow him to admit fault and possibly lose his prestige in the fictive community. However, the characters around him, in particular Matilda, use sophist reasoning to persuade him he is not at fault for his actions. We see Ambrosio blame Matilda for his first sexual encounter with her: " 'Dangerous Woman!' said He; "Into what an abyss of misery have you plunged me!" (Lewis 223). After Ambrosio rapes Antonia, he turns on the unfortunate girl and exclaims, "What seduced me into crimes, whose bare remembrance makes me shudder? Fatal Witch! Was it not thy beauty? Have you not plundered my soul into infamy?" (385). Schimmel writes that capital sins such as Lust become so encompassing that we lose sight of our own blame:

Although we may be initially reluctant ... to directly engage in grossly unjust actions in order to satisfy our desire for something, we are easily swayed to let others do the dirty work for us and to reap the benefits of their acting on our 
behalf. By being able to shift blame and responsibility to others we can rationalize our own evil behavior and assuage whatever guilty conscience we might have. (Schimmel 171).

It is Ambrosio's inattention to his guilty conscience-an agent we will later identify as actively endeavoring to show him his true self - and his living in Sartre's idea of "bad faith" that lead to his false intersubjective constitution with his fictive Lifeworld and thus to his eventual spiritual and physical demise at the hands of Satan.

\section{Ambrosio and Gluttony}

He no longer reflected with shame upon his incontinence, or dreaded the vengeance of offended heaven. His only fear was, lest Death should rob him of enjoyments, for which his long Fast had only given a keener edge to his appetite. (Lewis 224-5)

We have seen the capital sin of Pride lead Ambrosio into another capital sin, Lust; now, we shall examine how Ambrosio's Lust leads him into Gluttony. History has painted Gluttony as a capital sin involving food and drink, but Aquinas points out that, "Gluttony denotes, not any desire of eating and drinking, but an inordinate desire. Now desire is said to be inordinate through leaving the order of reason, wherein the good of moral virtue consists: and a thing is said to be a sin through being contrary to virtue. Wherefore it is evident that Gluttony is a sin" ("Question 148," par. 5). Perhaps one of the most memorable accounts in the Bible is the story of the towns Sodom and Gomorrah, which God commissioned angels to destroy because of their gluttonous acts of sensual sin:

And the two angels came to Sodom in the evening, and Lot was sitting in the gate of the city. And seeing them, he rose up and went to meet them: and worshipped prostrate to the ground,

And said, I beseech you, my lords turn in to the house of your servant and lodge there: wash your feet, and in the morning you shall go on your way. And they said: No, but we will abide in the street. 
He pressed them very much to turn in unto him: and when they were come in to his house, he made them a feast, and baked unleavened bread; and they ate:

But before they went to bed, the men of the city beset the house both young and old, all the people together.

And they called Lot, and said to him: Where are the men that came in to thee at night? Bring them out hither that we might know them. . . (DouayRheims The Holy Bible, Gen. 19: 1-5)

The angels blind the people at Lot's door and tell Lot to gather his family members and leave the cities before God destroys them. The next morning, the Lord rains fire and brimstone upon the cities and burns them to the ground.

The capital sin of Gluttony is exhibited in gothic works as well as the Bible: for example, in The Island of Dr. Moreau, we see Dr. Moreau set in motion the events that lead to his death when he continues to form animals into human-like creatures, constantly struggling to create the perfect creature in a gluttonous display of what he terms science. Moreau's gluttonous appetite for success for no specified reason benefitting humanity illustrates how we often seal our own fates when we engage in excess, and Lewis examines this same issue with Ambrosio in The Monk. By engaging in the capital vice of Lust, Ambrosio develops a gluttonous appetite for sex which hurtles him down the path to self-damnation in consciousness. In addition, his gluttonous appetite for carnal pleasures enables Matilda and Satan to secure Ambrosio's spiritual demise: "It is the inordinate desire of food that defiles a man spiritually," Aquinas writes (par. 6), and it is certainly the inordinate desire of sex that helps defile Ambrosio spiritually; although he satiates his lust at points throughout the text, he continues to crave physical pleasure and simply finds new objects of lust, such as Antonia, to objectify.

Ambrosio's first sexual encounter, with Matilda, is certainly a result of Lust; he has lusted after the portrait of the Virgin Mary in his room at the monastery, and Matilda 
has the same appearance as the woman in the portrait. Matilda craftily reveals her "beauteous orb" to Ambrosio and effects her stay at the monastery, leading to the moment of coitus that marks in the text Ambrosio's first indulgence in sexual pleasures. This event releases a torrent of desires:

He never saw, much less conversed with, the other sex: He was ignorant of the pleasures in Woman's power to bestow, and if He read in the course of his studies, "That Men were fond, He smiled, and wondered how!" For a time spare diet, frequent watching, and severe penance cooled and represt the natural warmth of his constitution: But no sooner did opportunity present itself, no sooner did $\mathrm{He}$ catch a glimpse of joys to which He was still a Stranger, than Religion's barriers were too feeble to resist the over-whelming torrent of his desires. All impediments yielded before the force of his temperament, warm, sanguine, and voluptuous in the excess. As yet his other passions lay dormant; But they only needed to be once awakened, to display themselves with violence as great and irresistible. (Lewis 238-9)

Lewis shows us Ambrosio lusting after the female penitents who come to confess to him, and this is how he meets Antonia and eventually seals his doom; Ambrosio's gluttonous lust is already in motion when he meets the hapless girl. The melody of Antonia's voice captures Ambrosio's attention, as does her countenance "so sweet, so innocent, so heavenly, as might have charmed an heart less susceptible, than that which panted in the Abbott's breast" (240). Ambrosio agrees to attend Antonia's mother at their home, breaking his vow never to leave the monastery in a physical representation of Ambrosio's intending of his physical world over the spiritual world. As he continues to visit Elvira to see Antonia, his designs change: although at first he maintains ruining such an innocent creature would be a black crime, he immediately begins her seduction. "He was not unconscious, that his attempts were highly criminal: He saw clearly the baseness of seducing the innocent Girl: But his passion was too violent to pernit his abandoning his 
design. He resolved to pursue it, let the consequences be what they might," Lewis writes $(257)$.

This plays perfectly into the trap Matilda and Satan have set for him, thus hurtling Ambrosio further down the path to self-damnation. In an act reminiscent of Amnon and his sister, Ambrosio thrusts Matilda to the side, even tearing the portrait of the Virgin Mary, which is the exact image of Matilda, from the wall and exclaiming, "The Prostitute!' (244) As he waits for an opportunity to seize Antonia, he becomes more cold toward Matilda; "Still, however, their illicit commerce continued: But it was clear, that He was led to her arms, not by love, but the cravings of brutal appetite. His constitution made a Woman necessary to him, and Matilda was the only one with whom He could indulge his passions safely: In spite of her beauty, He gazed upon every other Female with more desire" (236). However, Ambrosio dreads what may happen if he reveals his designs for Antonia to Matilda, so he avoids her (257). In a fit of passion, one day he clutches Antonia to him, but Elvira interrupts his actions. Ambrosio pretends nothing has happened and returns to the abbey; "Debarred the presence of Antonia, He had no hopes of satisfying that passion, which was now become a part of his existence" (265). Ambrosio turns to Matilda, who has offered him aid through the dark arts. He resists at first, but Matilda's sophist arguments, such as, "You will always have time to repent, and He have goodness to forgive. Afford Him a glorious opportunity to exert that goodness: The greater your crime, the greater his merit in pardoning" (270), along with a strategic image of Antonia in a magic mirror, are Ambrosio's undoing:

She was undressing to bathe herself. The long tresses of her hair were already bound up. The amorous Monk had full opportunity to observe the voluptuous contours and admirable symmetry of her person. She threw off her last garment, and advancing to the Bath prepared for her, She put her foot into the 
water. It struck cold, and she drew it back again. Though unconscious of being observed, an in-bred sense of modesty induced her to veil her charms; and She stood hesitating upon the brink, in the attitude of the Venus de Medicis. At this moment a tame Linnet flew towards her, nestled its head between her breasts, and nibbled them in wanton play. The smiling Antonia strove in vain to shake off the Bird, and at length raised her hands to drive it from its delightful harbor. Ambrosio could bear no more: His desires were worked up to phrenzy. 'I yield!' He cried, dashing the mirror upon the ground: 'Matilda, I follow you! Do with me what you will!' (271)

At this point there is a change of "wills"-Ambrosio, formerly in control of Matilda"s destiny, becomes her pawn. This will be especially important as we establish the actual steps on his path to self-damnation. Hence, Ambrosio's Gluttony of sensual pleasures leads him to lose control of his "self," in effect making him a puppet of Matilda and Satan.

Ambrosio and Greed

Often, the capital sins of Gluttony and greed are committed together. In the Douay-Rheims The Holy Bible, greed is most often associated with wealth; people are often greedy with money and physical possessions. This offers a special challenge in The Monk; how can Ambrosio, a monk who holds few physical possessions, be guilty of greed? In essence, Ambrosio's greed is for the fame he has garnered; there are numerous references to this in Lewis's text as noted above. Ambrosio guards his reputation at all costs, including the murder of Elvira to silence her regarding his transgressions against Antonia. The ideal-type religious consciousness during the Spanish Inquisition would have been aware of Jesus" teachings regarding Greed: "And he said to them: Take heed and beware of all covetousness: for a man's life doth not consist in the abundance of things which he possesseth" (Douay-Rheims The Holy Bible, Luke 12:15). Jesus 
continues: "And seek not what you shall eat or what you shall drink: and be not lifted up on high. For all these things do the nations of the world seek. But your Father noweth that you have need of these things. But seek ye first the kingdom of God and his justice: and all these things shall be added unto you" (Douay-Rheims The Holy Bible, Luke 12: 2931). In addition, Aquinas writes, "It may signify immoderation in the internal affection which a man has for riches when, for instance, a man loves them, desires them, or delights in them, immoderately. On this way by covetousness a man sins against himself, because it causes disorder in his affections. ..." ("Question 118," par. 8). Like the other capital sins, gothic literature examines the capital sin of Greed. For example, we often think of Ebenezer Scrooge in Charles Dickens's famous short story, "A Christmas Carol" (1848); the image of Scrooge counting his money as Bob Cratchit sits shivering in the outer office is certainly one to remain with us.

Perhaps Ambrosio's sin of Greed in the guise of love of Power is most grievous in his treatment of the unfortunate, specifically his lack of pity for Agnes. In this instance, Greed can be associated with a love of Power, whether that Power be the Power of God or the power Ambrosio's reputation lends him. Despite Agnes's pleas for mercy, Ambrosio insists upon revealing her secret letter to the Prioress, and Agnes presents her curse:

'Hear me!' She continued; 'Man of an hard heart! Hear me, Proud, Stern, and Cruel! You could have saved me; you could have restored me to happiness and virtue, but would not! You are the destroyer of my Soul; You are my Murderer, and on you fall the curse of my death and my unborn Infant's! Insolent in your yet-unshaken virtue, you disdained the prayers of a Penitent; But God will show mercy, though you show none. And where is the merit of your boasted virtue? What temptations have you vanquished? Coward! You have fled from it, not opposed seduction. But the day of Trial will arrive! Oh! then when you yield to impetuous passions! When you feel that Man is weak, and born to err; When shuddering you look back upon your crimes, and solicit with terror the mercy of 
your God, Oh! in that fearful moment think upon me! Think upon your Curelty! Think upon Agnes, and despair of pardon! (Lewis 48-9)

This is certainly an integral moment in Ambrosio's path to self-damnation; several times throughout the text he will reflect upon his treatment of Agnes and her ensuing curse. To his credit, he does endeavor to mediate Agnes's punishment with the Prioress, to no avail; "I have done my duty," Ambrosio says to himself (49), in spite of Jesus" teachings regarding the poor and unfortunate: "Then shall the just answer him, saying, Lord, when did we see thee hungry and fed thee: thirsty and gave thee drink? And when did we see thee a stranger and took thee in? Or naked and covered thee? Or when did we see thee sick or in prison and came to thee? And the king answering shall say to them, Amen I say to you, as long as you did it to one of these my least brethren, you did it to me" (DouayRheims The Holy Bible, Matthew 25:37-40).

\section{Ambrosio and Envy}

When we think of Envy, we often think of a green-eyed monster that consumes us from the inside, and this, in effect, is how this capital sin attacks Ambrosio spiritually; in fact, Ambrosio's Envy of "being in the world" leads to his spiritual Sloth, which leads directly to his disconnection with God and his phenomenological path to damnation. In Mark 7:20-24, Jesus warns of the dangers of Envy and many of the other capital sins:

But he said that the things which come out from a man, they defile a man. For from within, out of the heart of men, proceed evil thoughts, adulteries, fornications, murders, Thefts, covetousness, wickedness, deceit, lasciviousness, an evil eye, blasphemy, pride, foolishness. All these evil things come from within and defile a man. (Douay-Rheims The Holy Bible)

In gothic literature, Charlotte Dacre's Zofloya: Or the Moor (1808) examines the ills of Envy as Victoria, the principal character, solicits the aid of Zofloya (who is actually 
Satan posing as a mortal) and murders her husband as well as the woman who holds the heart of the man she loves. Soon atter, Victoria suffers the same fate as Ambrosio; Satan reveals her sins to her just before he hurls her from the top of a steep precipice. Victoria probably presented a frightening cultural iconography to readers, the ultimate "femme fatale" who soulessly plans the demise of her mate to gain the one she loves. In addition, Victoria presents a picture of a woman with no conscience, as Dacre's narrator specifies after Victoria's murder of her husband, Berenza: Victoria, "whom no feeling, however, of regrt or remorse for the cruel death inflicted by her on the most excellent of human beings," retires to her bedchamber after her husband is pronounced dead and almost immediately falls into sleep (Dacre 188). Victoria furthers her crimes by murdering her tival, Lilla, in a fit of Envy by throwing her from a mountaintop with no sign of remorse. In The Monk, Ambrosio's Envy is not for a specific person, but for anyone who would possess the possessors of the sensual pleasures of the world that he craves. For example, early in Lewis's text we see Ambrosio lust after his portrait of the Virgin Mary and, unwittingly, Envy God of this possession: "Oh! if such a Creature existed, and existed but for me!" (Lewis 41) When Ambrosio reflects upon the possibility of losing Matilda, he envies: "He reflected, that unsustained by hope her love for him could not long exist; That doubtless She would succeed in extinguishing her passion, and seek for happiness in the arms of One more fortunate" (86). As he ponders Antonia's future, he envies: “'Happy Man!' He exclaimed in his romantic enthusiasm; 'Happy Man, who is destined to possess the heart of that lovely Girl! .. What would I refuse to sacrifice, could I be released from my vows, and permitted to declare my love in the sight of earth and heaven?" (243) In Lewis's text, Ambrosio's Envy of those who might possess the 
women he desires seems superficial; it is addressed in only a few brief lines of text, although it is important to note that Ambrosio has an envious nature, as Lewis mentions: "He was jealous of his Equals, and despised all merit but his own" (237). The importance of Envy, however, is magnified tremendously when it leads Ambrosio to spiritual Sloth. As Aquinas writes, "The object of a man's sorrow is his own evil. . . Envy is a mortal $\sin$, in respect of its genus. For the genus of a sin is taken from its object; and Envy according to the aspect of its object is contrary to charity, which the soul derives its spiritual life. ..." ("Question 36," par. 27).

Ambrosio and Sloth

Persuaded of this, instead of humbling himself in penitence, of deploring his guilt, and employing his few remaining hours in deprecating Heaven's wrath, He abandoned himself to the transports of desperate rage; He sorrowed for the punishment of his crimes, not their commission; and exhaled his bosom's anguish in idle sighs, in vain lamentations, in blasphemy and despair. (Lewis 426)

There is little doubt that Pride, Lust, and Gluttony are the driving capital sins behind Ambrosio's phenomenological path to damnation. However, spiritual Sloth is as paramount as the first three capital sins in hurtling Ambrosio down the phenomenological path to damnation. For example, Ambrosio engages in Sloth after he suffers a night of sensual dreams about Matilda: "The Morning dawned. Fatigued, harassed, and exhausted by his provoking dreams, He was not disposed to quit his bed. He excused himself from appearing at Matins: It was the first morning in his life that he had ever missed them. $\mathrm{He}$ rose late" (84). Spiritual Sloth in The Monk is not as readily apparent as are the other capital sins; to establish it, we must read as much from what is not written and what is not specifically present in Ambrosio's thoughts but what would be present in the ideal-type 
religious consciousness during the Inquisition, as what is presented in the text, and we shall see that spiritual Sloth, or Ambrosio's sorrow over his lack of sensual pleasures and ensuing neglect of his worship of God, becomes an integral step on his path to selfdamnation. Aquinas writes:

Thus, in the genus of adultery, the concupiscence that goes no further than the sensuality is a venial sin, whereas if it reach to the consent of reason, it is a mortal sin. So too, the movement of Sloth is sometimes in the sensuality alone, by reason of the opposition of the flesh to the spirit, and then it is a venial sin; whereas sometimes it reaches to the reason, which consents in the dislike, horror and detestation of the Divine good, on account of the flesh utterly prevailing over the spirit. On this case it is evident that Sloth is a mortal sin" (Summa 563).

Aquinas adds that humankind shuns whatever causes sorrow; because Ambrosio's vows cause him sorrow by depriving him of the sensual pleasures he craves, he shuns his duty to God. This idea is echoed in the writings of Father Paul A. Duffner in "The Vice of Sloth": "Sloth, as understood in theology, is a sadness or dejection of the will about the divine good one possesses, and arises from a lack of esteem for that good, and for one's last end and the means to attain it. It occasions an aversion or repugnance in the will to the output of energy--whether physical or intellectual--in the service of God, and a tendency to negligence, arising from a lack of desire for, and joy in the divine good" (par. 11). Duffner maintains that Sloth is not mere laziness, but is instead a perverted sorrow. "Whereas true devotion brings a promptness of the will in the service of God, spiritual Sloth weighs down and oppresses the soul, bringing a voluntary distaste for spiritual things which become joyless burdens because of the abnegation and effort they demand, leading one to perform spiritual duties negligently, to shorten them, or eventually to omit them under vain pretexts," Duffner writes (par. 16). Lewis gives us a glimpse of this condition in Ambrosio's consciousness: 
The coolness of the night breeze and tranquility of the hour inspired the Friar's mind with sadness. He thought upon Matilda's beauty and affection; Upon the pleasures which he might have shared with her; Had he not been restrained by monastic-fetters. . . He shuddered at the void which her absence would leave in his bosom. He looked with disgust on the monotony of a Convent, and breathed a sigh towards that world from which he was forever separated" (86).

Ambrosio's spiritual sorrow is reflected through his inattention to the orders of his monkhood, such as matins; "He appeared at Matins; But his thoughts were absent, and He paid them but little attention. His heart and brain were both of them filled with wordly objects, and He prayed without devotion" (Lewis 68). However, Ambrosio also expresses it himself as he ponders how he can never possess Antonia because of the vows he has taken:

While his fancy coined these ideas, He paced his Cell with a disordered air. His eyes were fixed upon vacancy: His head reclined upon his shoulder; A tear rolled down his cheek, while He reflected that the vision of happiness for him could never be realized. 'She is lost to me!' He continued; 'By marriage She cannot be mine. ...' (243)

In Lewis's text, we see Ambrosio pay increasingly less attention to his duty as the leader of the monks and an icon in the community as he becomes preoccupied with lustful notions. After his tryst with Matilda, when he hears the confessions of women, he lusts after their persons more than he remedies their sins (240). And yet, as we have seen, our first experience of Ambrosio is comprised of his elocution to his supposed admirers. At that point, we have no reason to doubt his commitment to God; in fact, Lewis reminds us of it: "To deserve admittance into the order of St. Francis was Ambrosio's highest ambition" (237). It is only after Ambrosio tastes the sins of the flesh that he thrusts his love and fear of God to the inner recesses of his mind, from which we see it resurface several times when he is standing on the brink of a spiritual abyss, only for his self to cast it into the realms of passive awareness in light of possible new sensual experiences: 
Rash Matilda! What have you done? You have doomed yourself to endless perdition; you have bargained for momentary power eternal happiness! If on witchcraft depends the fruition of my desires, I renounce your aid most absolutely. The consequences are too horrible: I doat upon Antonia, but am not so blinded by lust, as to sacrifice for her enjoyment my existence both in this world and the next. (268)

And yet, after Matilda's sophist arguments ensue ["Are you then God's friend at present? Have you not broken your engagements with him, renounced his service, and abandoned yourself to the impulse of your passions? . . Tis not respect for God which restrains you, but terror of his vengeance!" (269)], Ambrosio indeed agrees for Matilda to use witchcraft to aid his designs for Antonia. In fact, Ambrosio continues to rely upon the idea of God's forgiveness as he progresses down the internal path to self-damnation, until, at some point, his self recognizes, albeit falsely, that there can be no forgiveness for him. We shall establish these points precisely as we examine the steps on Ambrosio's path to self-damnation.

\section{Ambrosio and Anger}

Lewis grants us a few glimpses of Ambrosio entertaining fits of anger; most often these occur when Ambrosio's plans of seduction are impeded. Anger because his sins have been discovered - not anger with his self because of the committance of sins-aids Ambrosio's final step on his phenomenological path to damnation. Aquinas writes that not all anger is sinful; "Anger ... is properly the name of a passion. A passion of the sensitive appetite is good in so far as it is regulated by reason, whereas it is evil if it set the order of reason aside ... The foolish are killed spiritually by anger, because, through not checking the movement of anger by their reason, they fall into mortal sins, for instance by blaspheming God or by doing injury to their neighbor" ("Question 158," par. 
16, 26). In addition, St. James the Apostle warns people should "be swift to hear, but slow to speak and slow to anger. For the anger of man worketh not the justice of God" (Douay-Rheims The Holy Bible James 1:19-20). We get a glimpse of Ambrosio in the transports of absolute fury after Elvira has interrupted his designs upon Antonia and told him his services are no longer needed at her home:

He had no hopes of satisfying that passion, which was now become a part of his existence. He reflected, that his secret was in a Woman's power: He trembled with apprehensions when He beheld the precipice before him, and with rage, when He thought that had it not been for Elvira, He should now have possessed the object of his desires. With the direct imprecations He vowed vengeance against her; He swore, that cost what it would, He still would possess Antonia. Starting from the Bed He paced the chamber with disordered steps, howled with impotent fury, dashed himself violently against the walls, and indulged all the transports of rage and madness. (Lewis 265)

This, of course, is an illustration of Ambrosio's anger at the impediment of his wishes upon Antonia. At this point in Lewis's text, Ambrosio has not directly expressed anger against God. While his sworn vengeance against Elvira is a capital sin per Aquinas ["If one desire the taking of vengeance in any way whatever contrary to the order of reason, for instance if he desire the punishment of one who has not deserved it. . . then the desire of anger will be sinful" ("Question 158," par. 22)], and his soul is in jeopardy because he has committed a capital vice, he has not completely relinquished his claim to salvation. We will establish this as a specific step on Ambrosio's path to self-damnation later in this work. For now, a brief look at Ambrosio's anger with God will suffice. It comes at the end of Lewis's text, as Ambrosio is in his prison cell awaiting trial by the Inquisition:

'Pardon?' He would cry in an access of phrenzy; 'Oh! there can be done for me!' Persuaded of this, instead of humbling himself in penitence, of deploring his guilt, and employing his few remaining hours in deprecating Heaven's wrath, He abandoned himself to the transports of desperate rage; He sorrowed for the 
punishment of his crimes, not their commission; and exhaled his bosom's anguish in idle sighs, in vain lamentations, in blasphemy and despair. (Lewis 426)

Afterward, Ambrosio signs his soul to Satan in a Faustian moment of despair, and Satan hurls him from the top of a mountain: "Blind, maimed, helpless, and despairing, venting his rage in blasphemy and curses, execrating his existence, yet dreading the arrival of death destined to yield him up to greater torments, six miserable days did the Villain languish" (442). Salvation was available to Ambrosio; his anger arises in part because he doubts this, which is an integral step on his phenomenological path to damnation. We have established Original sin and the Seven Deadly Sins as necessary pre-steps on Ambrosio's path. We now begin moving down the path itself. We begin our examination of the first step on the path, the beginning of the Fall of Ambrosio's self, with an application and re-envisioning of Ricoeur's idea of Defilement. 
1 Philosopher Arthur Schopenhauer (1788-1860) maintained that humans are rarely rational in their actions; instead, they are often "blindly driven by will to pursue their selfish desires" (Schopenhauer 146). Reason is used after-the-fact to rationalize what humans have done, Schopenhauer maintains. We will examine Schopenhauer's philosophy more as we progress down Ambrosio's phenomenological path to damnation.

2 The number three has tremendous significance in Biblical events. God sent the three messengers to Abraham to tell him that Sarah would conceive in her old age (Douay-Rheims The Holy Bible, Genesis 18); God brought a thick darkness upon the land of Egypt for three days (Exodus 10:22-23); Elijah stretches forth his body over a dead child three times, and the child lives again (1st kings 17:21); the Lord sends famine in the land for three years, and says it is because of Saul and his bloody house (2nd Samuel 21:1). In addition, the Holy Trinity is comprised of three entities: the Father, the Son, and the Holy Ghost. Perhaps the most famous use of the number three is the death of Jesus, who was resurrected on the third day after his death. In the film The Exorcism of Emily Rose (2005), a film that details a priest ${ }^{2} \mathrm{~s}$ struggle to save a young woman who is possessed by demons, $3 \mathrm{a} . \mathrm{m}$. is "the witching hour," or the hour demonic activity is most prevalent; it is the opposite of 3 p.m, the hour Jesus is thought to have died. 


\section{CHAPTER IV: THE SYMBOLISM OF DEFILEMENT: THE INITIAL STEP OF THE PHENOMENOLOGICAL PATH TO DAMNATION IN THE MONK}

Thou shalt sprinkle me with hyssop, and I shall be cleansed: thou shalt wash me, and I shall be made whiter than snow. .. Turn away thy face from my sins: and blot out all my iniquities. Create a clean heart in me, $O$ God: and renew a right spirit within my bowels. A sacrifice to God is an afflicted spirit: a contrite and humbled heart, $O$ God, thou wilt not despise. Psalm 51: 9-19, Douay-Rheims The Holy Bible

In the previous chapter, we examined the Seven Deadly Sins and how they successfully turn Ambrosio in The Monk toward the phenomenological path to damnation of the self. Hovering on the precipice of the entrance to the path, Ambrosio could focus intentionality upon salvation by simply confessing his sins; however, the sin of Pride prevents him from engaging in this act of salvation. His intersubjective constitution, or shaping and defining of his self with the defiled holy symbols, settings, events, and characters around him, entices him to exist in Sartre's idea of "bad faith," which, when layered upon his false intersubjective constitution, creates a binary opposition between his self and his conscience, as we shall see later in this work. Ambrosio's initial step down the phenomenological path to damnation of the self begins with defilement, the first segment of the triad of the experience of evil Ricoeur discusses in The Symbolism of Evil. For Ricoeur, defilement is the beginning of the reign of terror of evil because it is the first step toward the recognition that we have broken our covenant with the Hebrew God; as Aquinas writes, "the soul, by its own action, defiles itself, through cleaving to them (sinful acts) inordinately, against the light of reason and of the 
Divine law" (Summa 184). Ricoeur maintains defilement is expressed as a stain, and we see this evidenced when Ambrosio linguistically expresses his shame and horror after his initial sexual interaction with Matilda, as we shall examine later in this chapter. ${ }^{1}$ In addition, the act of defilement, the first step on the phenomenological path to damnation for Ambrosio, initiates the movement from Ricoeur's idea of the objective pole of sin to the subjective pole, as well as primes the conscience for its transition from the "unhappy conscience" to the "accused conscience," the conscience that is acutely aware of sin, or the transgression of the self from the Hebrew covenant. As Ricoeur writes, "It is only in the progress of conscience, as it advances beyond and at the same time retains the notion of defilement, that its meaning (the meaning of defilement) will be manifested" (46).

The Theme of Defilement in Gothic Literature and Art

I do not understand Lucy's fading away as she is doing. She eats well and sleeps well, and enjoys the fresh air; but all the time the roses in her cheeks are fading, and she gets weaker and more languid day by day; at night, I hear her gasping as if for air.... I trust her feeling ill may not be from that unlucky prick of the safety-pin. (Mina, Dracula 95)

The theme of defilement is prevalent in many works of gothic literature and art, including the work of Mary Shelley, in perhaps the most infamous gothic work of all time, Frankenstein (1818). Victor Frankenstein frequents charnel houses, where he finds pieces of human bodies to sculpt his creature. In addition, Victor studied the human body in its various stages of decay, and, as we shall examine in this chapter, The Holy Bible designates the dead and anyone who comes in contact with them as defiled. "I saw how the fine form of man was degraded and wasted; I beheld the corruption of death succeed to the blooming cheek of life; I saw how the worm inherited the wonders of the eye and brain," Victor states (Shelley 56). Victor's body becomes symbolic of the defiled: 
"Sometimes I grew alarmed at the wreck that I had become" (60), Victor says, and after giving birth to his creation, falls into a nervous fever representative of his physical and spiritual contamination. The creature, the living dead, is defiled at birth, which is evidenced in his description, a mixture of angelic and demonic. The creature's eyes, symbolic of the soul, are a dull yellow; his skin is yellow; yet his hair is "lustrous black, and flowing" and his teeth have a "pearly whiteness" (60). At the end of the text, we see Victor and his creature chasing each other across the arctic ice, with Victor either journeying toward his salvation through the sacrifice of his own life while endeavoring to destroy his creation, or running into the pits of hell reminiscent of the lowest level of Dante's $\underline{\text { Inferno, }}$, where we see Satan encapsulated in ice. We see similar forms of defilement in Robert Louis Stephenson's Strange Case of Dr. Jekyll and Mr. Hyde, where Hyde represents the defiled self of Jekyll after Jekyll drinks the potion to allow him to indulge in life's less-approved fancies without repercussion. Like Frankenstein's creature, Hyde is described as deformed and repulsive, and people develop an instant aversion to him. "It wasn't like a man; it was like some damned Juggernaut," Utterson maintains after Hyde has trampled a small girl. "But there was one curious circumstance. I had taken a loathing to my gentleman at first site" (Stephenson 3). This instance demonstrates the revulsion Utterson feels after his experience of Hyde's defilement, symbolized in Hyde's appearance and actions. In Samuel Taylor Coleridge's "The Rime of the Ancient Mariner," we see the Mariner spiritually defiled after shooting the albatross. To atone for his sin, he must endure the agony of near-death at sea as well as the torment of seeing his dead shipmates, a symbol of his guilt: "The pang, the curse, with which they died,/ Had never passed away: / I could not draw my eyes from theirs, I 
Nor turn them up to pray" (Coleridge 25). However, unlike Frankenstein and Ambrosio, as we shall soon examine, the mariner unwittingly cleanses himself when he blesses the water snakes, which are God's creatures: "O happy living things! No tongue / Their beauty might declare: / A spring of love gushed from my heart, / and I blessed them unaware: / Sure my kind saint took pity on me, / And I blessed them unaware. / The selfsame moment I could pray; / And from my neck so free / The Albatross fell off, and sank / Like lead into the sea" (20).

In gothic art, defilement is Figure 5: "The Nightmare" also prevalent. In Henry Fuseli's painting, "The Nightmare" (1781), we see a vulnerable woman with a demon-like creature seated on her chest. She lays in a posture reflective of the dead, although from the title of the painting we assume she is

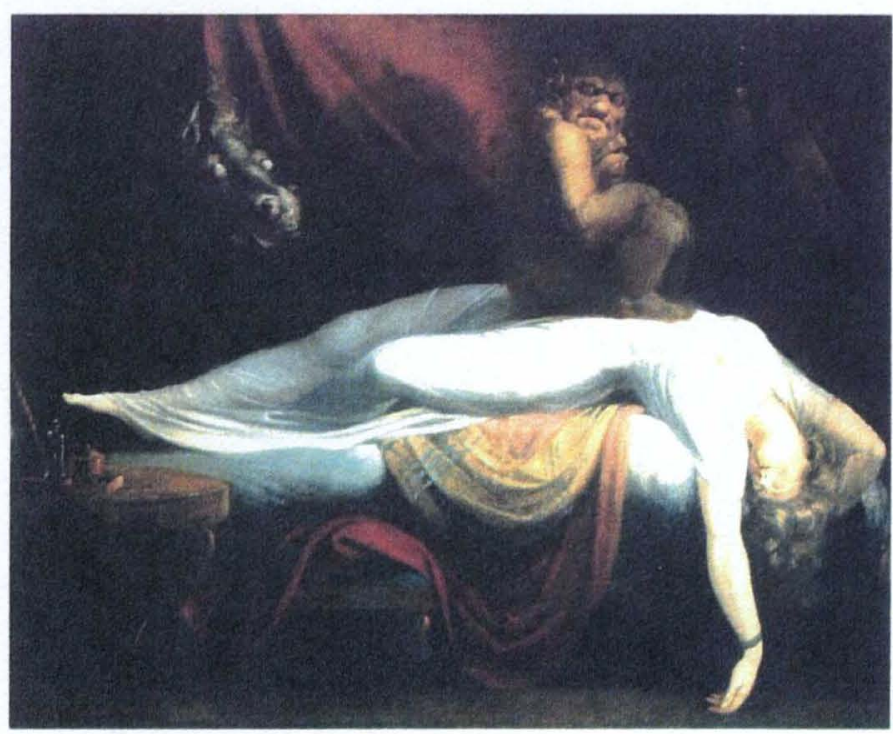
sleeping. Her impending defilement would be a spiritual one because of the symbolism of the creatures in the painting: a horse with no pupils, indicative of a creature with no soul, peers on as the creature seated on her chest looks at the viewer inquisitively. Her white garments symbolize her innocence because at this point, her defilement is not complete. ${ }^{2}$

Of all the gothic literature and art that addresses defilement, however, Bram Stoker's Dracula is perhaps the most potent. For our purposes, it is important to note that Lewis's The Monk and Stoker's Dracula share a symbolic tradition regarding defilement, 
even though Dracula was published 100 years after The Monk, illustrating the intrigue and significance of defilement in the objective mind of British culture during this period. Like the demon-like creature in Fuseli's creation, Count Dracula, the walking dead, defiles through corruption of the body and spirit of his victims, who become objects of his sexual terror; after one bite, we, too, become the walking dead if we succumb to the creature's mesmerizing force. However, the novel explores through its notion of defilement the binary opposition between scientific reason and legend: although it is Dracula's bite that "infects" his victims, leading them to death and ensuing life as the undead, Arthur Holmwood, a doctor in the text, maintains there is no scientifically verifiable pollution of Lucy Westenra's blood after the vampire bites her (Stoker 110): "I secured a few drops of the blood and have analysed them. The qualitative analysis gives quite a normal condition, and shows, I should infer, in itself a vigorous state of health," Holmwood writes (110). Instead of a physical contamination of the blood, when the blood is viewed as symbolic of our relation to God and Christ through the Eucharist and scripture such as Genesis 9:6: “Whosoever shall shed man's blood, his blood shall be shed: for man was made to the image of God" (Douay-Rheims The Holy Bible), the vampire robs us of our spiritual health and development. This idea is further solidified by the idea that the vampire's victim must die before transforming into the walking dead, a visible symbol of the spiritual defilement that transpires after the vampire's bite. As Dr. Seward writes:

When Lucy - I call the thing that was before us Lucy because it bore her shape-saw us she drew back with an angry snarl, such as a cat gives when taken unawares; then her eyes ranged over us. Lucy's eyes in form and colour; but Lucy's eyes unclean and full of hell-fire, instead of the pure, gentle orbs we knew. At that moment the remnant of my love passed into hate and loathing; had she then to be killed, I could have done it with savage delight. As she looked, her eyes 
blazed with unholy light, and the face became wreathed with a voluptuous smile. Oh, God, how it made me shudder to see it! With a careless motion, she flung to the ground, callous as a devil, the child that up to now she had clutched strenuously to her breast, growling over it as a dog growls over a bone. . . There was a cold-bloodedness in the act which wrung a groan from Arthur; when she advanced to him with outstretched arms and a wanton smile, he fell back and hid his face in his hands. (211)

Note the comparison of Lucy and her actions to an animal. As Lucy slowly transforms to the Undead and Unclean, she becomes more animal-like; her fangs grow, and her behavior becomes unrestrained and in defiance of logic. We shall see Ambrosio transform similarly as he progresses down the phenomenological path to damnation.

The Monk, like "The Rime of the Ancient Mariner," adds a salvation twist to the idea of defilement illustrated through the living dead, even as it uses this notion to damn Ambrosio. Agnes, for example, must journey into the realm of the dead and emerge as the living to be cleansed, while Ambrosio, on the other hand, is defiled spiritually the first time he descends into the sepulcher under the monastery and defiled physically when he murders Antonia on his second journey into the underground sepulcher. Unlike Agnes, he does not confess or regret his sins, and so is not cleansed, but defiled, by his journeys into death's realm. Because he is not "reborn" through his experiences among the dead, Ambrosio's "stain" of defilement spreads and transforms as his spiritual transgressions become more severe. "You are still too much the Monk," Matilda castigates him after he follows her into the sepulcher the first time, where she supposedly saves her own life by appealing to the dark forces (Lewis 234), indicating Ambrosio's stain is not complete at this point. On his second journey into the sepulcher, Ambrosio, as he awaits Matilda's signal, thinks he hears Agnes groaning, and, in a trick of foreshadowing, Lewis allows us access to the Monk's thoughts: "At that moment an idea which flashed into his mind 
almost petrified him with horror. He started, and shuddered at himself. 'Should it be possible!' He groaned involuntarily; 'Should it but be possible, Oh! What a Monster am I!" (274) Ambrosio ignores the warnings of his conscience and remembers only his own desires when Matilda returns to tell him all is ready for his meeting with Satan. At this point, Ambrosio defiles his spirit as he contemplates that he can always seek God's forgiveness later for the $\sin$ he is about to commit (274). Matilda chants, and the cavern under the Abbey is engulfed in a blue sulphorous fire, similar to the circles of blue fire Jonathan Harker sees when first traveling to Castle Dracula and symbolic of defilement through anti-baptism. ${ }^{3}$ Matilda primes Ambrosio's consciousness for future defilement when she states, "My magic arts will now be of no use to you: In future you can only hope for supernatural aid, by invoking the Daemons yourself, and accepting the conditions of their service" (278). Ambrosio's spiritual defilement is exhibited in his actions after the conclusion of his meeting with Matilda and Satan; instead of confessing his $\sin$, he "rejoiced in the fortunate issue of his adventure, and reflecting upon the virtues of the Myrtle, looked upon Antonia as already in his power. Imagination retraced to him those secret charms, betrayed to him by the Enchanted Mirror, and He waited with impatience for the approach of midnight" (279). After his murder of Elvira and Antonia and his imprisonment by the Inquisition, Ambrosio sees himself "stained with the most loathed and monstrous sins," indicative of his consciousness's awareness of his spiritual defilement; after he stabs Antonia, her blood stains his garments in a plot device similar to Shakespeare's Lady MacBeth and indicative of Ambrosio's accompanying bodily defilement for his sin. To begin our analysis of Ambrosio's progression into and through defilement, the first step of Ricoeur's triad in The Symbolism of Evil and the initial step 
on his path to damnation of the self, we must first examine how the ideal type religious consciousness would have been aware of defilement and its consequences.

Defilement in the Ideal Type Religious Consciousness

A person who, while given to works of piety, yields to the inconstancy of the flesh, is freed from eternal loss, in so far as these works dispose him to receive the grace to repent, and because by such works he makes satisfaction for his past inconstancy; but not so as to be freed by pious works, if he persist in carnal inconstancy impenitent until death.

("Question 154: The Parts of Lust," par. 33)

It is important to note here that Ambrosio experiences defilement initially, but even more importantly, the symbolic stain of his defilement becomes more varied and large because he does not seek forgiveness and cleansing; on the contrary, he continues performing more sinful acts, including the murder of his mother and the rape and murder of his sister, leading to increasing defilement of his person and his soul. In essence, Ambrosio's symbolic stain is an active one that spreads to permeate his entire existence. To progress down the phenomenological path to damnation, however, Ambrosio must experience defilement; thus we must examine how the ideal-type religious consciousness would have been aware of the concept of defilement and the need for cleansing. We will limit our examination of defilement in religious literature and philosophy to The Holy Bible and Christian religious philosophers before and during the Spanish Inquisition because those are the doctrines the ideal-type religious consciousness, which we equated with Ambrosio in Chapter 2 of this work, would have known.

The Old and New Testaments of the Bible contain numerous references to the concepts of defilement and cleansing necessary to rid oneself of it. Exodus 19: 3-15 discusses how the people of Israel had to prepare themselves to see God speaking to 
Moses through a cloud: "Go to the people, and sanctify them to-day and to-morrow; and let them wash their garments," God says to Moses. None of the Israelites is allowed into the mountain or to touch its borders. One who does so is to be slain immediately, but through methods that prevent touching of the defiled flesh (Douay 69, Exodus 19:13). On this day, men were not to go near their wives as well, implying that sexual pleasure results in defilement of the flesh and spirit, perhaps the most obvious of Ambrosio's defilements. There are numerous other examples, such as in the book of Numbers, which discusses the law for those who "consecrate themselves to the Lord":

They shall abstain from wine, and from every thing that may make a man drunk. They shall not drink vinegar of wine, or of any other drink: nor any thing that is pressed out of the grape. Nor shall they eat grapes either fresh or dried. ...

At the time of his separation, no razor shall pass over his head, until day be fulfilled of his consecration to the Lord. He shall be holy, and shall let the hair of his head grow.

All the time of his consecration he shall not go into any dead.

Neither shall he make himself unclean, even for his father, or for his mother, or for his brother, or for his sister, when they die: because the consecration of his God is upon his head. . . .

But if any man die suddenly before him, the head of his consecration shall be defiled. And he shall shave it forthwith on the same day of his purification: and again on the seventh day.

And on the eighth day he shall bring two turtles, or two young pigeons to the priest in the entry of the covenant of the testimony.

And the priest shall offer one for sin, and the other for a holocaust: and shall pray for him, for that he hath sinned by the dead. And he shall sanctify his head on that day. ...

And shall consecrate to the Lord the days of his separation, offering a lamb of one year for sin: yet so that the former days be made void, because his sanctification was profaned. (Douay-Rheims The Holy Bible, Numbers 6: 3-12)

The New Testament offers ideas regarding defilement and cleansing through the Passion of Christ. John 1: 14 declares, "And the Word was made flesh and dwelt among us (and we saw his glory, the glory as it were of the only begotten of the father), full of grace and truth" (Douay-Rheims The Holy Bible). Likewise, John 1: 29 maintains, "The 
next day, John saw Jesus coming to him; and he saith: behold the Lamb of God. Behold him who taketh away the sin of the world" (Douay-Rheims The Holy Bible). Jesus himself alludes to overcoming the defilement of $\sin$ in John 3:5: "Jesus answered and said to him: Amen, amen, I say to thee, unless a man be born again, he cannot see the kingdom of God" (Douay-Rheims The Holy Bible).

However, the ideal type religious consciousness's exposure to teachings regarding defilement and cleansing would not be limited to The Holy Bible. Aquinas examines these issues in Summa Theologica Question 86, "The Stain of Sin":

The stain of sin remains in the soul even when the act of sin is past. The reason for this is that the stain denotes a blemish in the brightness of the soul, on account of its withdrawing from the light of reason or of the Divine law. And therefore so long as man remains out of this light, the stain of sin remains in him: but as soon as, moved by grace, he returns to the Divine light and to the light of reason, the stain is removed. (Summa 184)

Aquinas discusses fornication, or "the union of an unmarried man with an unmarried woman," and maintains fornication is a species of lust ("Question 154," par. 6). Aquinas mentions different species of lust in addition to fornication: incest, which consists in the "misuse of a woman who is related by consanguinity or affinity,"; "adultery," if a woman is under the authority of her husband; "seduction," if the woman is under the authority of her father as opposed to a husband; and "rape" if violence is employed. If a women vows continence to God until marriage, "the sacrilege that is committed in the violation of such a woman is spiritual adultery" (par. 13).

With Aquinas's definitions and the ideas of defilement from The Holy Bible, the ideal-type religious consciousness, personified in Ambrosio, would be aware of its transgressions from the Hebrew covenant and resulting defilement. Per Aquinas's definitions, Ambrosio is spiritually and physically defiled in his sexual unions with 
Matilda and Antonia. He commits fornication with Matilda (although he would be aware that Matilda should be a virgin because she is not married, and thus, in his consciousness, he commits "spiritual adultery" as well), and he willfully commits spiritual adultery, fornication, and rape with Antonia. He also commits incest with Antonia, but he is unaware of his blood relation to her at the time of his actions. Aquinas writes that fornication is a "mortal sin" because the Bible labels it a crime: "Now crime denotes a mortal sin. Therefore fornication and all intercourse with other than one's wife is a mortal sin. Further, nothing but mortal sin debars a man from God's kingdom. But fornication debars him, as shown by the words of the Apostle (Galatians 5:21), who after mentioning fornication and certain other vices, adds: 'They who do such things shall not obtain the kingdom of God"” (pars. 23-24).

However, in addition to being aware of his transgressions against God (we have examined some of Lewis's language describing Ambrosio's thoughts regarding his defilement) and how they imperil his salvation through the Passion of Christ, Ambrosio avoids confession and its resulting atonement, an integral part of the cleansing of defilement and the explanation for the differing fates of Ambrosio and Agnes in The Monk. It is important here to examine why Agnes achieves salvation in the text and Ambrosio is damned because the notion of defilement and cleansing is integral to the idea of defilement. In an ironic twist of plot, Ambrosio is instrumental in the salvation of Agnes because he dooms her to her fate at the hands of the Prioress when he forces her confession by revealing her letter. Agnes has engaged in sexual relations with Don Raymond, the Marquis de la Cisternas after her pledge to become a nun, and finds herself pregnant. She attempts to conceal her crime by planning with Raymond to leave the 
convent, but she drops a note she is planning to leave for Raymond detailing her situation. Ambrosio discovers the note. When Agnes pleads for mercy, Ambrosio responds:

Your boldness confounds me! Shall I conceal your crime, I whom you have deceived by your feigned confession? No, Daughter, no! I will render you a more essential service. I will rescue you from perdition in spite of yourself; Penance and mortification shall expiate your offence, and Severity force you back to the paths of holiness. (Lewis 47)

Ambrosio's language reflects the idea of defilement and cleansing in the ideal type religious consciousness during the Inquisition; confession followed by "penance and mortification" are necessary to cleanse. Ambrosio deliberately avoids these, but his action-giving Agnes's letter to the Prioress-helps secure Agnes's salvation through her "forced" confession and resulting atonement for her sin. These actions cleanse her defilement. The Prioress imprisons Agnes in a small cell in the sepulchral underground of the convent, symbolic of Anges's journey into "death" and her resurrection when she is rescued, where Agnes gives birth to her child. The child dies almost immediately after birth, reminiscent of God's punishment to David for his adultery with Bathsheba:

"Nevertheless, because thou hast given occasion to the enemies of the Lord to blaspheme for this thing, the child that is born to thee, shall surely die" (Douay-Rheims The Holy Bible The Holy Bible 2 Kings 12:14). David tries to atone for his sin: "And David besought the Lord for the child: and David kept a fast, and going in by himself lay upon the ground. And the ancients of his house came, to make him rise from the ground: but he would not, neither did he eat meat with them" (12:16-7). Note that David's acts of atonement are public. Ambrosio makes no attempt at any such acts, and in fact avoids them to protect his public image. Agnes's “confession," which Ricoeur maintains is 
integral to the religious consciousness, is her letter Ambrosio finds; in it, she details her crime of fornication and her plan to circumvent the crime by eloping with Don Raymond. After Ambrosio finds her letter and makes it public, the Prioress sentences her to expire in the underground dungeon, surrounded by death and decay symbolic of a rotting corpse in the grave. She describes her "hell," reminiscent of the creature-ridden grave:

Far from growing familiar with my prison, I beheld it every moment with new horror. The cold seemed more piercing and bitter, the air more thick and pestilential. My frame became weak, feverish, and emaciated. I was unable to rise from the bed of Straw, and exercise my limbs in the narrow limits, to which the length of my chain permitted me to move. Though exhausted, faint, and weary, I trembled to profit by the approach of Sleep: my slumbers were constantly interrupted by some obnoxious insect crawling over me. Sometimes I felt the bloated Toad, hideous and pampered with the vapours of the dungeon, dragging his loathsome length along my bosom: Sometimes the quick cold Lizard roused me leaving his slimy track across my face, and entangling itself in the tresses of my wild and matted hair: Often have I at waking found my fingers ringed with the long worms, which bred in the corrupted flesh of my Infant. (Lewis 415)

Through this journey into death and resurrection into Life when she is rescued, Agnes's defilement is cleansed.

It is important to note here that there are a multitude of associations to be made regarding Agnes and the dichotomy of salvation/damnation she experiences, as well as her role on Ambrosio's phenomenological path to damnation, which we shall explore in subsequent chapters of this work. However, even though it is possible to document Agnes's phenomenological path to salvation in complete detail and in opposition to Ambrosio's phenomenological path to damnation, it would prove too cumbersome for this work. For example, unlike Agnes, Ambrosio resists confession, an integral step toward salvation, because of the pride that urges him to protect his public image, as we discussed in Chapter 3 of this work. We now move to Ricoeur's idea of defilement and Ambrosio's phenomenological experience of it. 
Ricoeur's Idea of Defilement and a Phenomenology of Ambrosio's Defilement

Dread of the impure and rites of purification are in the background of all our feelings and all our behavior relating to fault. (Ricoeur, The Symbolism of Evil 25)

With defilement we enter into the "reign of Terror," Ricoeur writes (25). Note the implication of the phrase with the period of mass guillotining in France 1793-4; the period was one of terror in France, much like the fear associated with the notion that we are "lesser than" or "soiled" in the eyes of God when we are defiled. We enter the "reign of terror" because we begin to focus intentionality, or our specific consciousness at that time, upon our breach of the Hebrew Covenant. As we have seen, the ideal type religious consciousness during the Inquisition would have been aware of defilement and the need for ritualistic cleansing after it. "But a few weeks had elapsed, since he was pure and virtuous .... He now saw himself stained with the most monstrous sins," Lewis writes of Ambrosio (421). However, Ricoeur maintains defilement is difficult for us to reenact today; "what resists reflection is the idea of a quasi-material something that infects as a sort of filth, that harms by invisible properties" (26). For example, what was once viewed as "defilement" is, in many cases, no longer considered such. When Gothic literature peaked in England in the late 1790s, a woman's "virtue" was something to be cherished-without it, she became "ruined." Antonia weeps at the end of The Monk when Ambrosio rapes her; "her piece of mind was lost, her honour irreparably ruined. She was cut off forever from society, nor dared He give her back to it," Lewis writes and gives us a glimpse into Ambrosio's perception of Antonia's defilement at his hands (386). Antonia herself queries Ambrosio, "What, would you more? ... Is not my ruin compleated? Am I not undone, undone for ever?" (386). Today, however, our moral values are different; no longer is a woman "ruined" if her virginity is lost, even at an 
early age. "We no longer understand what the substance-force of evil, the efficacy of a something that makes purity itself an exemption from defilement and purification an annulment of defilement, could be," Ricoeur writes (26).

Even though we cannot experience defilement today (and I would maintain that we can, depending upon which cultures and sub-cultures of which we are a part), Ricoeur also discusses the objective and subjective points of view of defilement. Dread is the subjective part of the experience of defilement (and thus fault), while the symbolic representation of defilement is its objective portion. Ambrosio experiences dread after his first tryst with Matilda: "The burst of transport was past: Ambrosio's lust was satisfied; Pleasure fled, and Shame usurped her seat in his bosom. Confused and terrified at his weakness He drew himself from Matilda's arms. His perjury presented itself before him: He reflected on the scene which had just been acted, and trembled at the consequences of a discovery" (Lewis 223). Yet, even though Ambrosio experiences his defilement on this subjective level, he also perceives it on an objective level, as Ricoeur maintains, through the symbols in his culture and language associated with it. To establish this, we must look to the linguistics of his verbal communication, the symbolism of his non-verbal communication, and the role of intersubjective constitution for Ambrosio and his Lifeworld.

Ambrosio's Intersubjective Constitution with the Symbols of Defilement in his Lifeworld As we read the symbols with which Ambrosio's self is intersubjectively constituted, it is important to keep in mind the role of intersubjective constitution in our intending of our Lifeworlds. We have mentioned that Ambrosio exists in a fictive 
Lifeworld; however, we will find many aspects of his intersubjective constitution are very similar to our own in our Lifeworlds. We turn to Edmund Husserl, the Father of Phenomenology, for ideas regarding this intersubjective constitution. In his Cartesian Meditations, Husserl maintains that our constant synthesis of streams of experience in our Lifeworlds leads to our "constitution" of it. When we "constitute" an object, we continually verify its existence through our experience of it. For example, Ambrosio constitutes God and morality through his constant experience of them, which leads, in part, to his false intersubjective constitution: at no point in The Monk is God present, which leads us to believe Ambrosio has never experienced "God," and this, coupled with his false intersubjective constitution with Matilda (he "reads" her as a young woman, when she is, in fact, a demon; he "reads" her as mentally superior to himself, and her words and actions are simply to manipulate him down the path to damnation) vaults him down the phenomenological path to damnation. Husserl explains:

Yet, as a matter of essential necessity, external experience alone can verify objects of external experience, though, to be sure, it does so only as long as the (passively or actively) continuing experience has the form of a harmonious synthesis. That the being of the world "transcends" consciousness in this fashion (even with respect to the evidence in which the world presents itself), and that it necessarily remains transcendent, in no wise alters the fact that it is conscious life alone, wherein everything transcendent becomes constituted, as something inseparable from consciousness, and which specifically, as world-consciousness, bears within itself inseparably the sense: world —and indeed: "this actually existing" world. (62)

It is through our constitution of the Lifeworld that we are able to make sense of the objects and events occurring every day, and that we can exist, for the most part, in the "natural attitude" without questioning every aspect of every object we experience.

For Husserl, we constitute our everyday Lifeworld through acts of active and passive genesis. During active genesis, the Ego is "productively constitutive" and 
combines acts into syntheses that constitute new objects originally, and these "then present themselves for consciousness as products" (77). "Thus, in collecting, the collection is constituted; in counting, the number; in dividing, the part; in predicating, the predicate and the predicational complex of affairs; in inferring, the inference; and so forth," Husserl writes (77). Works of practical reason are active genesis, such as when Ambrosio rationalizes his decision to allow Matilda to stay at the monastery after she has revealed she is a woman.

We begin applying the concept of intersubjective constitution to Ambrosio and his Lifeworld by examining the language he and those around him use, as well as the non-verbal communication clues the text gives us. This will lead us to an analysis of how the symbols we have interpreted so far help catapult Ambrosio down the phenomenological path to damnation through Ambrosio's false intersubjective constitution with them. We have already examined how Ambrosio is guilty of many of the Seven Deadly Sins, such as Pride and Lust. For readers, these are certainly an initial step toward defilement for him. However, we must note that he does not experience these directly as defilement; in fact, he seems blissfully unaware of his commitance of them. He does not directly experience these, in part, because they are "hidden" sins, and thus are not intersubjectively constituted for him. If they had been intersubjectively constituted, perhaps he would at that point have sought forgiveness and ritualistic cleansing that would have been his salvation. Instead, he is further vaulted down the phenomenological path to damnation because of his unawareness of them. Ambrosio's defilement at this point is only constituted by the law of God he knows from his studies at the monastery; it is not authentically intersubjectively constituted with another being in 
his Lifeworld until he encounters Elvira when he is actively trying to seduce Antonia.

We, however, must begin at the point where he is aware of his defilement. It begins with his "as-if" sexual experience with Matilda, his dream where he gets just to the point of achieving sexual pleasure when he awakes:

The Friar slept well; But the dreams of the former night were repeated, and his sensations of voluptuousness were yet more keen and exquisite. The same lust-exciting visions floated before his eyes: Matilda, in all the pomp of beauty, warm, tender, and luxurious, clasped him to her bosom, and lavished upon him the most ardent caresses. He returned them as eagerly, and already was on the point of satisfying his desires, when the faithless form disappeared, and left him to all the horrors of shame and disappointment. (Lewis 84)

Lewis tells us Ambrosio experiences "shame and disappointment," or conflicting emotions representative of the war between his conscience and his self. Ambrosio is aware that the actions he performed during this "as-if" experience violate his vows of chastity and his Order and endanger his relationship with God, which leads to the emotion, "shame." 4 is also aware that the physical pleasure was one he desired, which leads to his feeling of "disappointment." 5 Ambrosio's actions solidify this hypothesis: the next morning, he does not attend Matins, "the first morning in his life that He had ever missed them," because he feels "fatiqued, harassed, and exhausted by his provoking dreams" (84). At this point, Ambrosio is too ashamed to confess the defilement of his "as-if" experience to anyone; in addition, because his "as-if" experience is not intersubjectively constituted with anyone around him-there is no one with which to discuss the experience, and he risks horrible danger to his reputation if he didAmbrosio's self can deny the mirror his conscience holds for him and he can successfully rationalize Matilda's stay at the monastery despite the dangers he knows it entails. As Lewis's narrator states, "Ambrosio was yet to learn, that to an heart unacquainted with 
her, Vice is ever most dangerous when lurking behind the Mask of Virtue" (84). It is directly after his "as-if" sexual experience with Matilda that is soon to make itself physically manifest in his Lifeworld that Ambrosio begins to doubt his role in the monastery:

The coolness of the night-breeze and tranquility of the hour inspired the Friar's mind with sadness. He thought upon Matilda's beauty and affection; Upon the pleasures which He might have shared with her; had He not been restrained by monastic-fetters. He reflected, that unsustained by hope her love for him could not long exist; That doubtless She would succeed in extinguishing her passion, and seek for happiness in the arms of One more fortunate. He shuddered at the void which her absence would leave in his bosom. He looked with disgust upon the monotony of a Convent, and breathed a sigh towards that world, from which $\mathrm{He}$ was for ever separated. (86)

Note here that Ambrosio's intentionality has changed. To this point in the text, Ambrosio has intended his fame and reputation, and possibly God; at this point, however, he begins to intend pleasures of the physical world. Ambrosio does commit the sin of lust when he is gazing at the portrait of the Virgin Mary, which later is revealed as the direct image of Matilda; he intends his lust toward a portrait in an "as-if" experience of an ethereal, unattainable being. Here, Ambrosio actually begins to intend the physical pleasures associated with a living object that has entered his Lifeworld-Ambrosio's "horizon" has expanded beyond the realm of the religious and mystical of the monastery to the physical world existing outside that Holy Space. Introduced to the "disgraceful passion," as Matilda terms it, of sexual pleasure, Ambrosio protests but little before he relinquishes his mind and body to Matilda's charms in a consummation of his intending of the physical over the spiritual:

The hour was night. All was silence around. The faint beams of a solitary Lamp darted upon Matilda's figure, and shed through the chamber a dim mysterious light. No prying eye, or curious ear was near he Lovers: Nothing was heard but Matilda's melodious accents. Ambrosio was in the full vigour of 
Manhood. He saw before him a young and beautiful Woman, the preserver of his life, the Adorer of his person, and whom affection for him had reduced to the brink of the Grave. He sat upon her Bed; His hand rested upon her bosom; Her head reclined voluptuously upon his breast. Who then can wonder, if He yielded to the temptation? Drunk with desire, He pressed his lips to those which sought them: His kisses vied with Matilda's in warmth and passion. He clasped her rapturously in his arms; He forgot his vows, his sanctity, and his fame: $\mathrm{He}$ remembered nothing but the pleasure and opportunity. (Lewis 90)

To assess Ambrosio's intersubjective constitution of his spiritual and physical defilement resulting from this union with a demon—although, remember, he is not aware at this point that Matilda is a demon-we turn to his and Matilda's reactions after the event. Lewis's narrator tells us that after Ambrosio's lust is satisfied, "pleasure fled, and Shame usurped her seat in his bosom" (223). He is "confused and terrified" at his weakness and withdraws himself from Matilda's arms in a non-verbal act symbolic of his shame; in addition, "His perjury presented itself before him: He reflected on the scene which had just been acted, and trembled at the consequences of discovery. He looked forward with horror; His heart was despondent, and became the abode of satiety and disgust" (223). Ambrosio's conscience is an active agent, pointing out how he has transgressed the primary tenets of his covenant with God, which is a direct result of Ambrosio's constitution of that Divine Law. However, his intersubjective constitution with Matilda presents a conflicting translation of the event. Matilda states: "Unnatural were your vows of Celibacy; Man was not created for such a state; And were Love a crime, God never would have made it so sweet, so irrestible! Then banish those clouds from your brow, my Ambrosio! Indulge in those pleasures freely, without which life is a worthless gift: Cease to reproach me with having taught you, what is bliss, and feel equal transports with the Woman who adores you!" (224) The demon-led false intersubjective constitution, or shaping and defining of the self with the settings, events, and characters 
around him, succeeds as Ambrosio and Matilda immediately begin another sexual escapade, and Ambrosio's struggle between his self and his conscience, which holds a mirror for him to view his true self, begins. He rationalizes that the crime is committed, so why should he not enjoy its reward? "Intoxicated with pleasure, the Monk rose from the Syren's luxurious Couch. He no longer reflected with shame upon his incontinence, or dreaded the vengeance of offended heaven. His only fear was, lest Death should rob him of enjoyments, for which his long Fast had only given a keener edge to his appetite," Lewis's narrator tells us (224-5). Ambrosio realizes he could not find another mistress easily, so he pleads for Matilda to save herself from the snake's poison. She does, effectively ensuring the spread of Ambrosio's defilement.

At this point in the text, however, we also see Matilda change roles from Eve the Companion to Eve the Serpent, as mentioned in Chapter Two of this work. As Rosario, Matilda is Ambrosio's faithful and beloved companion; however, Matilda's transition to Eve the Serpent is complete with her temptation of Ambrosio. She forewarns the Monk of her role before their union: "I shall no longer be able to combat my passions, shall seize every opportunity to excite your desires, and labour to effect your dishonour and my own," she states (89). Her words are too true. After their initial sexual interlude, Ambrosio exclaims, "Wretched Matilda! You have destroyed my quiet forever!" (223) She is, indeed, instrumental in the growing stain of defilement Ambrosio experiences as he progresses down the phenomenological path to damnation, and it is this growing stain, viewed in the light of sin, guilt, and punishment-further steps along the path—that eventually leads him to damn his own self before any divinity or anti-divinity damns him. Recall, however, that Ambrosio has no person with which to intersubjectively constitute 
his defilement except Matilda, a demon whose mission is to lure him to damnation, and her false intersubjective constitution through her sophist arguments related to his transgressions lends Ambrosio a false sense of security. He believes-truthfully, if we are to believe the narrator of Lewis's text — that he can ask God's forgiveness at any time and receive it, and so he continues his crimes that permeate defilement through his soul and being.

Ambrosio's stain of defilement continues through more sexual trysts with Matilda and begins to spread horrifically when he begins lusting after Antonia. As we shall see, he progresses from one who is "acted upon" by evil to one who "acts upon" others; in other words, as he progresses and his stain of defilement spreads, he becomes an active agent of evil, evidenced not only by his thoughts, but by his physical actions as well. This could be, in part, because of his false intersubjective constitution with the evil agents around him, whom he perceives as "not evil." For example, after tiring of his encounters with Matilda, he willfully neglects her. She, of course, senses his coldness and reveals that she knows his secret: he is lusting after Antonia. His efforts to gain possession of Antonia's person illustrate he will stop at nothing to secure his goal. In direction violation of his vows, Ambrosio agrees to visit Elivira, Antonia's mother, at their abode: "He could leave the Abbey unobserved without difficulty: By wrapping up his head in his Cowl He hoped to pass through the Streets without being recognized: By taking these precautions, and by recommending secrecy to Elvira's family, He doubted not to keep Madrid in ignorance that He had broken his vow never to see the outside of the Abbey-walls," Lewis's narrator tells us (244). In addition to aiding the growth of his defilement stain through deceit, we see a shift in Ambrosio's intentions toward Antonia. When he first 
converses with her regarding her mother's physical condition, he maintains, "Fear not, lovely Girl! Your virtue runs no risque from me. Not for Indies would I make that gentle bosom know the tortures of remorse" (244); however, as Lewis's narrator warns:

He was willfully blind to the danger of exposing himself to Antonia's charms .... At first He bounded his wishes to inspire Antonia with friendship: But no sooner was He convinced that She felt that sentiment to its fullest extent, than his aim became more decided, and his attentions assumed a warmer colour. The innocent familiarity with which She treated him, encouraged his desires: Grown used to her modesty, it no longer commanded the same respect and awe: He still admired it, but it only made him more anxious to deprive her of that quality, which formed her principal charm.... He easily distinguished the emotions which were favourable to his designs, and seized every means with avidity of infusing corruption into Antonia's bosom.... He was not unconscious, that his attempts were highly criminal: He saw clearly the baseness of seducing the innocent Girl: But his passion was too violent to permit his abandoning his design. He resolved to pursue it, let the consequences be what they might. (257)

Note here that, like Matilda's self-confessed design for Ambrosio, Ambrosio intends to "corrupt" Antonia and to pollute the "Holy Space" of her person, much as his actions to secure her further pollute the Holy Space of the abbey; his own "Holy Space," his body, is already defiled, and thus polluted, at this point. He attempts to rape Antonia in a chamber at her home and is thwarted by her mother, Elvira, who was not fooled by the Monk's reputed virtue. Alarmed at some of the stories her daughter has told her she heard from Ambrosio, Elvira vigilance pays off when she nearly catches Ambrosio trying to rape Antonia; only the sound of the door saved the Monk from direct proof of his lewd and defiled spirit. This is the first time in the text we see Ambrosio's actions intersubjectively constituted with another human (remember, Matilda is a demon, although Ambrosio is not aware of this), and "shame and confusion" reign on Ambrosio's face. He knows his actions are a violation of his sacred duty and vows. Elvira tells him he is no longer needed as her confessor, and he returns to the Abbey, "his heart filled with 
rage and shame, with bitterness and disappointment" (264). Here we see him transform physically into the anti-Divine:

Ambrosio hastened to his Cell. He closed the door after him, and threw himself upon the bed in despair. The impulse of desire, the stings of disappointment, the shame of detection, and the fear of being publicly unmasked, rendered his bosom a scene of the most horrible confusion. He knew not what course to pursue. Debarred the presence of Antonia, He had no hopes of satisfying that passion, which was now become a part of his existence. He reflected, that his secret was in a Woman's power: He trembled with apprehension when He beheld the precipice before him, and with rage, when He thought that had it not been for Elvira, He should now have possessed the object of his desires. With the direct imprecations He vowed vengeance against her; he swore, that cost what it would, He still would possess Antonia. Starting from the Bed he paced the chamber with disordered steps, howled with impotent fury, dashed himself violently against the walls, and indulged all the transports of rage and madness. (264-5)

$\mathrm{He}$ is interrupted by a knock on the door, almost as if his demonic actions have called the dark forces to his aid. It is Matilda, who tells him she can help him secure Antonia by appealing to the "infernal spirits" who are in her command. At first Ambrosio rejects her offer, but Matilda's sophist arguments_-“Are you then God's Friend at present? Have you not broken your engagements with him, renounced his service, and abandoned yourself to the impulse of your passions? Are you not planning the destruction of innocence, the ruin of a Creature, whom He formed in the mould of Angels? If not Daemons, whose aid would you invoke to forward this laudable design? .. . You will always have time to repent, and he have goodness to forgive" (269-70)-coupled with her magic mirror showing Ambrosio an image of a naked Antonia- secure Ambrosio's acceptance of her offer and further spread and darken the stain of his defilement. "I yield! Matilda, I follow you! Do with me what you will!" he exclaims (271). The forces of darkness are further falsely intersubjectively constituted for him when he sees Matilda call Satan, a beautiful youth of about 18 , to his aid: "Enchanted at a vision so contrary to his expectations, Ambrosio gazed upon the Spirit with delight and wonder" (277). After 
the ritual, Ambrosio's "faculties were all bound up in pleasure, anxiety, and surprise" (277), and he retires that evening feeling no remorse, yet eagerly anticipating midnight, when he will use the magic myrtle Matilda secured from Satan to effect Antonia's ruin. Ambrosio's defilement approaches a pinnacle when he murders Elvira to secure Antonia's ruin. Here, Ambrosio secures true intersubjective constitution as Elvira responds to seeing him, an intruder, in her home:

It is really Ambrosio, who stands before me! It is the Man whom Madrid esteems a Saint, that I find at this late hour near the Couch of my unhappy Child! Monster of Hipocrisy! I already suspected your designs, but forbore your accusation in pity to human frailty. Silence would now be criminal: The whole City shall be informed of your incontinence. I will unmask you, Villain, and convince the Church what a Viper She cherishes in her bosom. (301)

Although Ambrosio acknowledges, to himself, that his punishment would be just (303), he attempts to flee the room. Elvira stops him by grabbing hold of his arm. "And worked up to madness by the approach of ruin, He adopted a resolution equally desperate and savage," Lewis's narrator tells us (303), and Ambrosio smothers Elvira with a pillow. His actions are reminiscent of the two demon-possessed men in Matthew 8:28-33, whom Jesus heals: "And when he was come on the other side of the water, into the country of the Gerasenes, there met him two that were possessed with devils, coming out of the sepulchres, exceeding fierce, so that none could pass by that way" (Douay-Rheims The Holy Bible). Yet, we see an essence of humanness or divinity intact in him still when he realizes the enormity of his crime: "Ambrosio shuddered at himself, when He reflected on his rapid advances in iniquity. The enormous crime which He had just committed, filled him with real horror. The murdered Elvira was continually before his eyes, and his guilt was already punished by the agonies of his conscience" (305). However, Lewis's narrator tells us Ambrosio feels less remorse as days pass and he is not approached with 
suspicion: "He began to resume his spirits; and as his fears of detection died away, $\mathrm{He}$ paid less attention to the reproaches of remorse" (305).

Ambrosio's stain of defilement grows with the commitance of his next crimes: the rape and murder of Antonia. This is where Lewis's text digresses a bit from the traditional literary gothic: while many gothic novels contain a real or perceived threat of rape, few follow through with it; Lewis's text, on the other hand, lends readers a "soft porn" look at the deed, which posed a threat of defilement to Lewis and to those who read the work. As discussed in Chapter 1, Samuel Taylor Coleridge's review of The Monk specified:

"The sufferings which he [Lewis] describes are so frightful and intolerable, that we break with abruptness from the delusion, and indignantly suspect the man of a species of brutality, who could find a pleasure in wantonly imagining them; and the abominations which he pourtrays with no hurrying pencil, are such as the observation of character by no means demanded, such as 'no observation of character can justify, because no good man would willingly suffer them to pass, however transiently, through his own mind" (Coleridge)

It is as if Coleridge's sentiments are echoed in the character of Ambrosio; as Ambrosio's defilement continues, we see more of his continuing transformation from the holy to the demonic, as evidenced in his physical actions and his mental states. He resorts to deception without regard to the pain of others, much as Matilda has with him throughout the text, when he gives Antonia a potion that induces a death-like trance upon her. Ambrosio delivers her absolution before she "dies" and arranges her burial in the underground sepulcher of the convent adjacent to his monastery. We get a glimpse into his consciousness as he looks upon Antonia, still unconscious and surrounding by rotting corpses, in the sepulcher:

'For your sake, Fatal Beauty!' murmured the Monk, while gazing on his devoted prey; 'For your sake, have I committed this murder, and sold myself to 
eternal tortures. Now you are in my power: The produce of my guilt will at least be mine. Hope not that your prayers, breathed in tones of unequalled melody, your bright eyes filled with tears, and your hands lifted in supplication, as when seeking in penitence the Virgin's pardon; Hope not, that your moving innocence, your beauteous grief, or all your suppliant arts shall ransom you from my embraces. Before the break of day, mine you must, and mine you shall be!' (379)

Here we see illustrated the defilement of Ambrosio's religious consciousness as he mutates from the "defiled" or the "polluted" to the "defiler" and the "polluter." Earlier, we saw Ambrosio remark that he could seek forgiveness from God at any point and receive it; here, we see him prepared to deny Antonia the pardon he expects his God to extend to him. In addition, we see his thoughts mirror Matilda's when he reasons why Antonia should simply give herself to him: “Yet why reject pleasures so sweet, so rapturous? No one observes us; Our loves will be a secret to all the world: Love and opportunity invite you giving loose to your passions. . . Amidst all her gifts, has Nature denied her most precious, the sensibility of Pleasure?" (382) After the conclusion of his crime, Ambrosio denies the mirror image his conscience holds for his self by blaming Antonia for his actions as he looks upon her with "aversion and rage" (384), and yet we see he is aware of the message his conscience sends him:

I know well the weight of my offences; Well, that your complaints would be too just, and my crimes too notorious! . . that my conscience is loaded with sins, which make me despair of Heaven's pardon. . . . And who am I to thank for this? What seduced me into crimes, whose bare remembrance makes me shudder? Fatal Witch! Was it not thy beauty? Have you not plunged my soul into infamy? Have you not made me a perjured Hypocrite, a Ravisher, an Assassin! Nay, at this moment does not that angel look bid me despair of God's forgiveness? Oh! When I stand before his judgement-throne, that look will suffice to damn me! You will tell my Judge, that you were happy, till I saw you; that you were innocent, till I polluted you! You will come with those tearful eyes, those cheeks pale and ghastly, those hands lifted in supplication, as when you sought from me that mercy which I gave not! Then will my perdition be certain! Then will come your Mother's Ghost, and hurl me down into the dwellings of Fiends and flames, and Furies, and everlasting torments! And 'tis you, who will accuse me! 'Tis you who will cause my eternal anguish! $(385)^{6}$ 
Ambrosio's spiritual defilement is nearly complete at this point; all that remains for him is the murder of Antonia, which completes his physical defilement, and the resignation of his soul to Satan, which seals his physical and spiritual doom. In addition, throughout the transition we have noted from Ambrosio the holy to Ambrosio the unholy, there has been an accompanying movement of his conscience from the "unhappy conscience" to the "accused conscience." We examine this movement next.

Ambrosio's Movement through Defilement from the "Unhappy Conscience" to the "Accused Conscience"

Ricoeur maintains that, through language, the interdict and the confession, the defiled self becomes conscious of itself (41). However, Ambrosio does not confess, which allows him to live in bad faith with his conscience; his self, although aware of its defilement, does not admit of it in the beginning of his transgressions against the Hebrew covenant, although his self becomes more aware of its defilement, sin, guilt, and ensuing punishment as his stain of defilement grows. For Ricoeur, the movement from defilement to sin and guilt is a linear one; we must experience one to move to the next. For Ambrosio's consciousness, as we have examined, the movement from one area, such as defilement, does not necessarily end when the progression into "sin" begins. Instead, Ambrosio's stain of defilement continues to grow and aids in his transportation down the phenomenological path to damnation. We see this living stain evidenced in the transition of Ambrosio's consciousness from the "unhappy conscience" to the "accused conscience" (note that I have adapted this term from Ricoeur's idea of the "accused and condemned" conscience because there is a distinct movement from the "accused" 
conscience" to the "condemned conscience" in Ambrosio's phenomenological path to damnation), which results after the idea of defilement progresses to the idea of $\sin$.

Ambrosio's "unhappy conscience" is illustrated through the lack of success of it as an active agent to show his self a true picture of itself. For example, Lewis's narrator shows us Ambrosio's internal struggle after he has raped Antonia; he feels remorse for what he has done and hatred for the object of his desire that he believes was responsible for his actions. He even experiences a brief aspect of self-damnation when he remarks that Antonia will damn him from salvation. For our purposes, the "unhappy conscience" engages the self in a constant struggle to achieve an authentic self, or one that does not live in Sartre's idea of "bad faith," and we see this when Ambrosio feels remorse, a direct message from the conscience, one moment but buries that feeling the next. The "unhappy conscience" transforms into the "accused conscience" when the self realizes it is not only defiled, but has transgressed the word of God, or broken the Hebrew covenant, and thus "sinned." We shall examine this in the next chapter as Ambrosio progresses to the next step on the phenomenological path to damnation: Sin and Sin Consciousness. 


\section{Endnotes}

1 Because this work analyzes the thoughts and consciousness of a fictive character existing in a fictive world, we must look even beyond language to establish how Ambrosio experiences events in his Lifeworld. Lewis's narrator tells us the monk feels shame, and after his tryst with Matilda, Ambrosio feels "embarrassed" when he enters the Chapel; "He fancied that every eye could read the transactions of the night upon his countenance," Lewis writes (226). Ricoeur maintains defilement is experienced as a stain, and these clues Lewis offers support the idea that Ambrosio is experiencing his defilement as a stain.

2 For an examination of Fuseli's work as a combination of romanticism and classicism, see Jed Perl's "Troubled classicism: The Hyper Personality of Henry Fuseli's Work" in Modern Painters (July/August 2006) p. 80-5. For a reading of the incubus as humorous rather than sinister, see Z. Dana Andrus's "Some Implications for Another Reading of Henry Fuseli's 'The Nightmare"' in Gazette des Beaux-Arts v. ser6 no. v126 (December 1995) p. 235-52.

3 My definition of anti-baptism is the opposite of traditional Catholic baptism the ideal-type religious consciousness would know. Traditional baptism involves holy water; anti-baptism involves submergence or defilement by fire, especially blue fire reflective of the cold at the innermost circle of Dante's Inferno. Traditional Catholic baptism reflects a person's acceptance into the Catholic faith, as well as the acknowledgment of all people as sinners; anti-baptism leads to commission of Capital sins. It is important to note that John the Baptist, in Matthew 3:11, maintains that he baptizes with water, but that Jesus, who would follow him, would baptize with the Holy Spirit and with fire; obviously the fire would cleanse instead of defile, unlike the blue fires associated with these gothic texts.

4 For a more detailed analysis of the idea of shame in literature, and especially Shakespeare, see Ewan Fernie's Shame In Shakespeare, London: Routledge, 2002.

5 This is a perfect example of Ricoeur's idea of the "servile will," or the idea that we desire to fulfill the requisites of the Hebrew covenant (or whatever religion with which we associate), but we are trapped inside bodies that experience, and in some cases are slaves to, physical pleasure.

6 An association with a preceding novel may prove useful here. The idea of rape and its ensuing shame is also evidenced in Samuel Richardson's novel Clarissa, in which Lovelace drugs and rapes Clarissa and recalls a dream in which Clarissa is an angel and he is about to be swallowed into hell. Clarissa was a must-read for the $18^{\text {th }}$-century educated reader, so it is highly possible Lewis was familiar with it. 


\title{
CHAPTER V: MOVEMENT FROM THE "UNHAPPY CONSCIENCE" TO THE "ACCUSED CONSCIENCE": SIN CONSCIOUSNESS AS PROGRESSION ON THE HERMENEUTICAL-PHENOMENOLOGICAL PATH TO DAMNATION IN THE MONK
}

\begin{abstract}
But when the will turns away from the unchangeable and common good toward its own private good, or toward external or inferior things, it sins. It turns toward its own private good when it wants to be under its own control; it turns toward external things when it is keen on things that belong to others or have nothing to do with itself; it turns toward inferior things when it takes delight in physical pleasure. In this way one becomes proud, meddlesome, and lustful; one is caught up into a life that, by comparison with the higher life, is death. But even that life is governed by divine providence, which places all things in their proper order and gives everyone what he deserves. (Augustine, On Free Choice of the Will 68)
\end{abstract}

In Chapter 4 of this work, we examined how Ambrosio in The Monk is physically and spiritually defiled through his illicit actions with Matilda and Antonia, as well as his murder of his own mother, Elvira, and Antonia, his sister. Ambrosio's recognition that his actions have transgressed the Hebrew covenant, his contract with God, leads us and him to the subsequent step on his phenomenological path to damnation: sin and sin consciousness. "His perjury presented itself to him," Lewis writes in a glimpse into Ambrosio's consciousness immediately after Ambrosio's first sexual liaison with Matilda (223); the use of the word "perjury" certainly implies Ambrosio is aware that his action transgressed his covenant with God, reminding us of the role of the will in sin that Augustine describes in On Free Choice of the Will: "Woe to those who turn away from your light and gladly embrace a darkness of your own," Augustine writes(68). This idea of the will as the subjective movement within that drives us is integral to Ricoeur's idea 
of the "servile will," or the will that is trapped inside a body susceptible to sensations that naturally lead to sin; it is also integral in our analysis of Ambrosio's movement from the "unhappy conscience," an entity that engages the self in a constant struggle to achieve an authentic self-or one that does not live in Sartre's idea of "bad faith"---to the "accused conscience," when the self realizes it is not only defiled, but has transgressed the word of God and thus "sinned." This idea of sin is Ricoeur's next schema in The Symbolism of Evil, and thus is a formal step on Ambrosio's phenomenological path to damnation. However, it is important to note that although Ambrosio progresses from one step on the phenomenological path to damnation to the next, he does not simply move beyond previous steps as he advances. Instead, the steps have permeable boundaries, and Ambrosio moves along and between them, gathering inaccurate evidence through his incessant false intersubjective constitution, or defining and shaping of his self, with other primary characters, settings, and events in the text. For example, Ambrosio continues to experience himself as defiled, as discussed in Chapter 4 of this work, even though he has progressed from the "unhappy conscience" to the "accused conscience," or a conscience that realizes he has sinned.

Before we begin an analysis of sin and sin consciousness in The Monk, we look at the notion of sin consciousness in gothic literature and art. This will illustrate how Lewis is writing from a rich gothic literary tradition, one that began before him and continues today. The popularity of the gothic in Lewis's time is evidenced in the chart below, from Jerrold Hogle's The Cambridge Companion to Gothic Fiction (43), which depicts the number of gothic novels published in the period 1790-1800. Lewis,writing The Monk in 1796 , could be relatively assured the reading public was familiar with gothic tropes. 
Figure 6: Proliferation of Gothic Novels 1770-1800

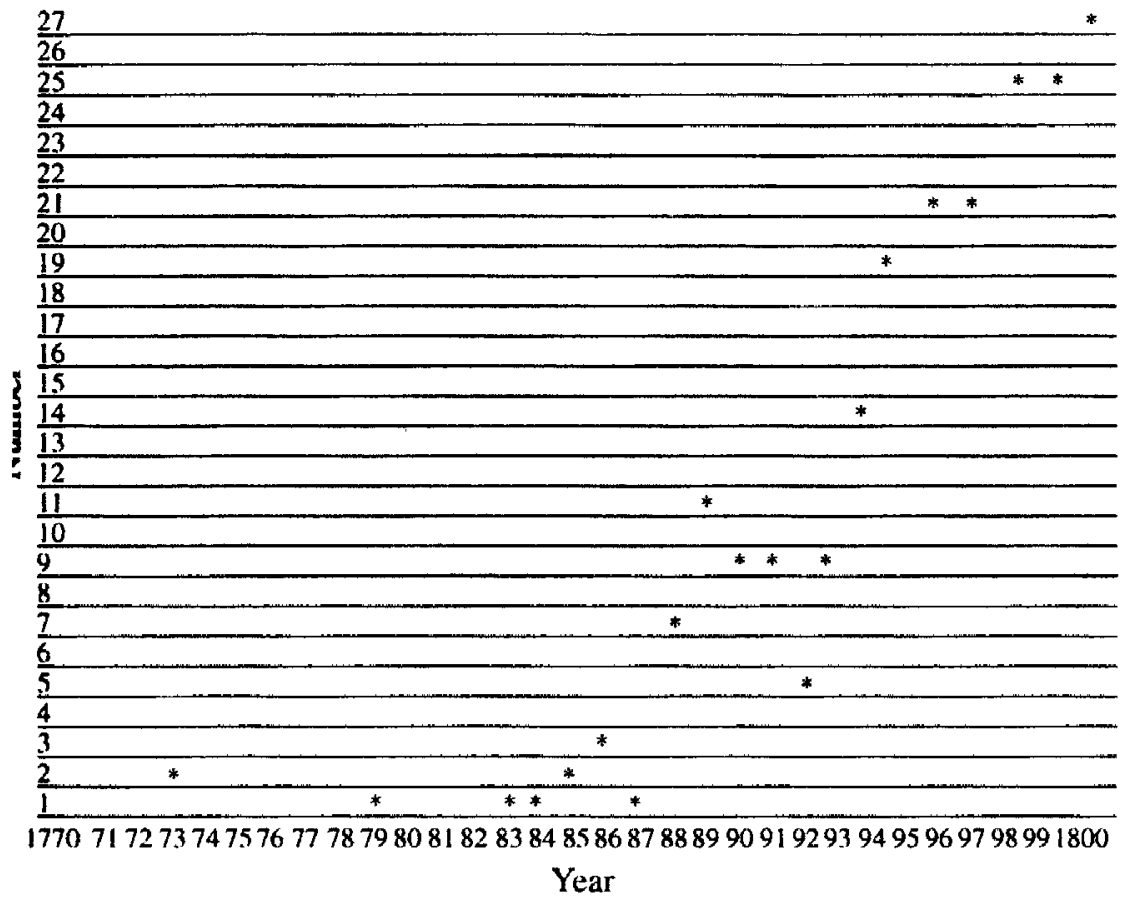

Sin Consciousness in Gothic Literature and Art

One morning, in cool blood, I slipped a noose about its neck and hung it to the limb of a tree -- hung it with the tears streaming from my eyes, and with the bitterest remorse at my heart -- hung it because I knew that it had loved me, and because I felt it had given me no reason of offence -- hung it because I knew that in so doing I was committing a sin -- a deadly sin that would so jeopardize my immortal soul as to place it -- if such a thing were possible -- even beyond the reach of the infinite mercy of the Most Merciful and Most Terrible God. (Poe, "The Black Cat” 322)

In Chapter 4 we examined the role of defilement as it pertains to Victor Frankenstein and his creature in Mary Shelley's Frankenstein (1818), as well as defilement in Bram Stoker's infamous novel, Dracula (1897). Defilement in these texts leads to the notion of sin, much as defilement is a precursor to sin for Ambrosio in Lewis's The Monk. We need look no further than the works of Edgar Allen Poe (18091849 ) and Nathaniel Hawthorne (1804-1864) for an illustration of sin in gothic literature-the work of both writers is rife with theories regarding transgressions from the 
Hebrew covenant. These texts will illustrate how gothic tropes Lewis addressed continued to be part of the gothic tradition after publication of The Monk; also, a brief look at these works will illustrate how the methodology for establishing a phenomenological path to damnation for gothic characters can be applied to other works of gothic fiction because many of the works share the similar tropes. In addition, Poe's works often address the role of the Will in sin, which is integral in our movement from the "unhappy conscience" to the "accused conscience" for Ambrosio. In Poe's "Ligeia," we see Ligeia on her deathbed, determined not to succumb to death: "O God! O Divine Father! - shall these things be undeviatingly so? - shall this Conqueror be not conquered? Are we not part and parcel in Thee? Who--who knoweth the mysteries of the will with its vigor? Man doth not yield him to the angels, nor unto death utterly, save only through the weakness of his feeble will" (Poe 117). At the end of the tale, Ligeia's spirit moves into the body of the author's newest love, thus ensuring her immortality. Ligeia's transgression is one against the will of God, ultimately served through death. It is important to note here that Ligeia receives no punishment for her transgression, although Ambrosio is certainly punished for his.

In Poe's "The Black Cat," we see a popular gothic theme of the symbolism of sin depicted on or to those who have sinned. In this tale, a narrator haunted by the "fiend intemperance," alcohol, takes a penknife and cuts out one of the eyes of his cat, Pluto; a bit afterward, the narrator hangs the cat. That evening his house expires in flames, and we see his " $\sin$ " of cruelty to God's creature evidenced on a brick wall of the house that is left standing:

About this wall a dense crowd were collected, and many persons seemed to be examining a particular portion of it with very minute and eager attention. 
The words 'strange!' 'singular!' and other similar expressions, excited my curiosity. I approached and saw, as if graven in bas relief upon the white surface, a gigantic cat. The impression was given with an accuracy truly marvelous. There was a rope about the animal's neck. (323)

The hanged cat predicts the narrator's fate: after a second black cat aids the police in discovering the narrator has murdered his wife and encased her corpse within a brick wall in the basement, the narrator faces the gallows. Similar to the image of the cat symbolizing the narrator's transgression and fate, in The Monk we see Elvira's ghost symbolizing Ambrosio's sin and predicting Antonia's death: "Yet three days, and we meet again!" the ghost moans to Antonia (318). Note that the symbol of the hanged cat is presented directly to the consciousness of the narrator in Poe's story. In The Monk, Elvira's ghost as a symbol of his sin is never presented directly to Ambrosio's consciousness, possibly indicative of Ambrosio living in "bad faith," his self refusing to acknowledge its sin to his conscience.

The idea of sin is prevalent as well in the works of Nathaniel Hawthorne, a Poe contemporary. In fact, Hawthorne's "The Man of Adamant" involves a man who perceives himself as holy, when in fact he is the opposite, much like Ambrosio in The Monk. Unlike Jesus in the New Testament, Richard Digby determines that to ensure his salvation, he must remove himself completely from the company of other mortals; as he is leaving the village, he cannot understand why it is not consumed in fire and brimstone "now that the one righteous man had provided for his own safety" (46). Digby sequesters himself inside a dark cave, where he reads continuously from the Bible and drinks water running from adamant inside the cave. He thrusts aside his one chance at salvation when a ghost, Mary Goffe, visits him: 
"Richard," she said, with passionate fervor, yet a gentleness in all her passion, "I pray thee, by thy hope of heaven, and as thou wouldst not dwell in this tomb forever, drink of this hallowed water, be it but a single drop! Then, make room for me by thy side, and let us read together one page of that blessed volume,--and, lastly, kneel down with me and pray! Do this, and thy stony heart shall become softer than a babe's, and all be well." But Richard Digby, in utter abhorrence of the proposal, cast the Bible at his feet, and eyed her with such a fixed and evil frown, that he looked less like a living man than a marble statue.... (49)

Many years later, children discover the "man of adamant," Richard Digby, turned to stone in the sepulchral cave he chose as his home for eternity. The image is reminiscent of Lot's wife in the Bible, when she disobeys orders from angels and looks back at the destruction of Sodom and Gomorrah, and is transformed immediately into a statue of salt

(Genesis 19: 26 Douay-Rheims The Holy

Bible 17).

In gothic art, the works of William

Blake (1757-1827) often depict religious

symbolism, including the notion of sin. In

Blake's "Satan, Sin, and Death: Satan Comes

to the Gates of Hell" (c. 1806, right), a

depiction of a scene in Book II of John

Milton's Paradise Lost, we see Satan, enroute

to tempt Adam and Eve, confronted by Death.

Sin, the daughter of Satan, is shown as half
Figure 7: "Satan, Sin, and Death"

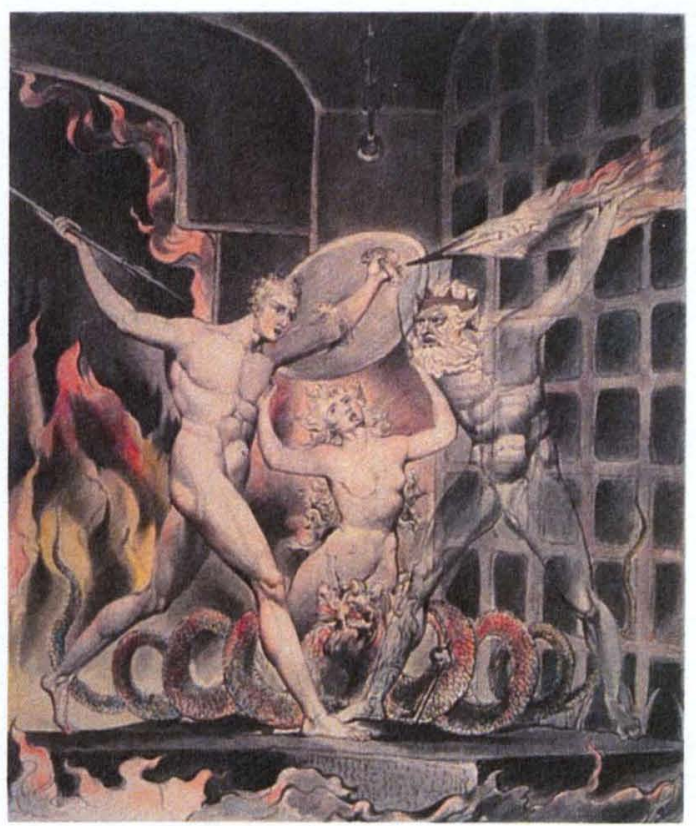

woman, half serpent, and she separates the two figures and reveals Death is the offspring of her and her father. In Romans 6:23, the apostle Paul states, "For the wages of sin is death. But the grace of God, life everlasting in Christ Jesus our Lord" (Douay-Rheims The Holy Bible 156). 
Although an in-depth analysis of Blake may prove cumbersome here and detract from our primary goal of establishing the phenomenological path to damnation for Ambrosio in The Monk, it may prove beneficial to readers to examine a bit of Blake's history because of his prominence as a Romantic artist. According to Mellor and Matlak, Blake believed God is man, "not rational man but natural, spontaneous, innocent man" (273). Blake concluded There is No Natural Religion (1788) with, "God becomes as we are, that we may be as he is" (273). Blake had a great admiration for the Middle Ages and "came closer than any other Romantic artist to Figure 8: "The Ancient of Days" reviving Renaissance forms" (Janson 643). We see Blake's ideas and influences present in his image, "The Ancient of Days" (1794, right). In this work, Janson maintains, Blake has composed a medieval representation of the Architect of the Universe, but instead of the Ancient of Days reflecting God, he represents the power of reason, which Blake regarded as destructive (643). Blake was known for attacking ideologies such as the religious

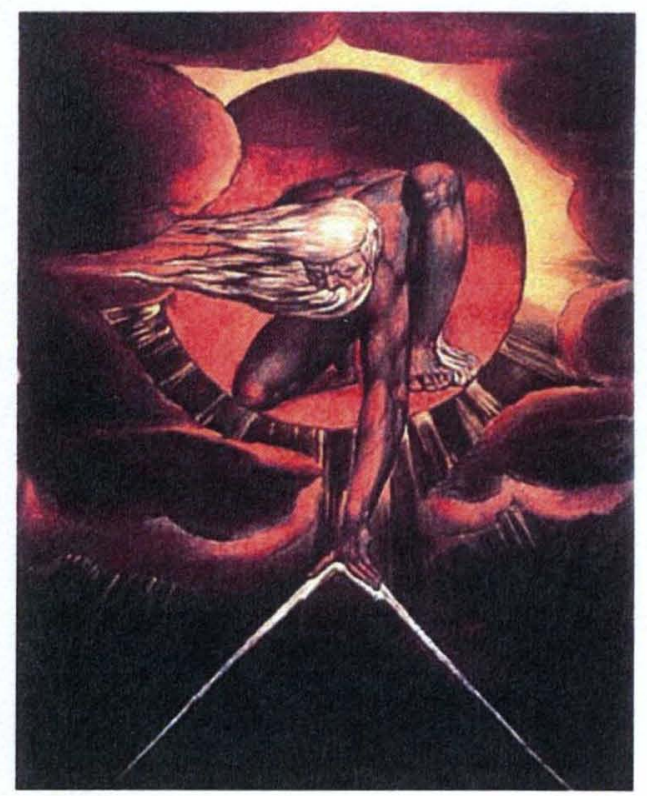
doctrines of the Anglican Church and the Enlightenment emphasis on human reason as opposed to emotion, ideas Lewis echoes in The Monk through the superstition and supernatural themes and characters prevalent throughout the work. ${ }^{1}$

With that in mind, we now move to an examination of the concept of sin among religious philosophers Anselm, Augustine, and Aquinas, along with a brief examination 
of the concept of $\sin$ in scripture. This will provide a foundation for the idea of sin in the ideal-type religious consciousness we have equated with Ambrosio's consciousness.

The Biblical Notion of Sin

As it is written: There is not any man just. ... All have turned out of the way: they are

become unprofitable together: there is none that doth good, there is not so much as one. St. Paul 3:10-12 (Douay-Rheims The Holy Bible 153)

According to Genesis, sin is an act of disobedience to the will and law of God, born from the actions of Adam and Eve in the Garden of Eden, which we explored in Chapter 2. Sin is punished by God, as God punished Adam and Eve by expelling them from the Garden. This idea of sin permeates the Old Testament, and is revisited and revised by Jesus in the New Testament, in which Jesus becomes the instrument of salvation from sin for humankind. In Matthew 15: 19-20, Jesus maintains sin is inside man: "But the things which proceed out of the mouth come forth from the heart: and those things defile a man. For from the heart come forth evil thoughts, murders, adulteries, fornications, thefts, false testimonies, blasphemies. These are the things that defile a man" (Douay-Rheims The Holy Bible 17). In this passage, Jesus teaches that sin comes from the heart, implying that it is an act of will that leads to sin, as we shall examine throughout this chapter. As Aquinas writes, "The soul is not defiled by inferior things, by their own power, as though they acted on the soul: on the contrary, the soul, by its own actions, defiles itself, through cleaving to them inordinately, against the light of reason and of the Divine law" (Summa 186). Aquinas's idea echoes the thought that the steps on Ambrosio's phenomenological path to damnation are indeed permeable, and that even as he recognizes he has transgressed God's eternal law and "sinned," he continues 
to feel the stain of defilement transmitted by his sin. "Now, when the soul cleaves to things by love, there is a kind of contact in the soul: and when man sins, he cleaves to certain things, against the light of reason and of the Divine law .... Wherefore the loss of comeliness occasioned by this contact, is metaphorically called a stain on the soul," Aquinas writes (186).

However, sin is distinguished from defilement by the act of will necessary to commit sin. Aquinas maintains original sin is a privation of original justice, and the entire order of original justice consists of man's will being subject to God (note how Adam and Eve directly disobeyed the will of God) (An Aquinas Reader 379). All individual sin thus is a direct descendent of the original sin of Adam and Eve: "It is primarily related to that power wherein resides the first inclination to commit sin, and this is the will," Aquinas writes (382). It also takes a direct act of the will to remove a stain of sin: "But as soon as, moved by grace, he returns to the Divine light and to the light of reason, the stain is removed. For although the act of sin ceases, whereby man withdrew from the light of reason and of the Divine law, man does not at once return to the state in which he was before, and it is necessary that his will should have a movement contrary to the previous movement" (187). We shall examine Aquinas's ideas of redemption and punishment in the final chapter of this work.

Some readers may assert that, contrary to the idea of free will necessary to commit sin, Satan is indeed the "unmoved mover" of Ambrosio's sinful acts because he obviously manipulates the monk throughout Lewis's text. At the end of the novel, Satan reveals he sent Matilda, a demon, to deliberately lead Ambrosio astray after Satan became aware of Ambrosio's capital sin of Pride. "I long have marked you for my prey: I 
watched the movements of your heart; I saw that you were virtuous from vanity, not principle, and I seized the fit moment of seduction," Satan says (Lewis 440). However, Aquinas refutes this idea of Satan as the principle cause of humankind's sin when he concludes that nothing other than the will makes man a slave to his desires, so Satan is not the cause of $\sin ($ Summa 160):

The devil is the occasional and indirect cause of all our sins, in so far as he induced the first man to $\sin$, by reason of whose sin human nature is so infected, that we are all prone to sin: even as the burning of wood might be imputed to the man who dried the wood so as to make it easily inflammable. He is not, however, the direct cause of all the sins of men, as though each were the result of his suggestion. Origen proves this (Peri Archon iii, 2) from the fact that even if the devil were no more, men would still have the desire for food, sexual pleasures, and the like; which desire might be inordinate, unless it were subordinate to reason, a matter that is subject to the free-will. (160)

The Holy Bible in James: 4:7 confirms Aquinas's ideas: "Be subject therefore to God.

But resist the devil: and he will fly from you" (235).

We find similar doctrines in the writings of medieval philosopher St. Anselm of Canterbury (1033-1109). In "On Free Will," Anselm maintains sin began as an act of free will, and that free will exists even after we have made ourselves slaves of $\sin (178)$. The power of free will cannot be taken from humankind or angels unless they will it (181). In addition, and in contradiction to the idea that Satan manipulated Ambrosio to sin, Anselm asserts that although our will seems powerless, it is indeed powerful against temptations:

We often say that we cannot do something, not because it is impossible for us, but because we can do it only with difficulty. This difficulty does not destroy freedom of the will. Temptation can fight against a will that does not give in but cannot conquer it against its will. In this way I think we can see how the power of the will as established by true arguments is compatible with the impotence our humanity experiences. For just as difficulty does not in any way destroy the freedom of the will, so that impotence, which we assign to will because it can retain its rectitude only with difficulty, does not take away from the power to persevere in rectitude. (185) 
Even God cannot remove the rectitude of the will, Anselm writes (186). However, one who abandons the rectitude of the will because of the difficulty of following "right will" becomes a "slave" to sin who cannot restore the will without Divine aid: "Because it [the will] cannot return from sin, it is a slave; because it cannot be robbed of rectitude, it is free. But from its sin and slavery it can return only by the help of another, although it can depart from rectitude only by itself' (189). This idea is similar to philosopher Paul Ricoeur's idea of the "servile will," which we will examine next in relation to Ricoeur's idea of $\sin$ in The Symbolism of Evil.

Sin Consciousness in Ricoeur's The Symbolism of Evil

Does not sin make God the Wholly Other? (Ricoeur, The Symbolism of Evil 58)

We examined Ricoeur's idea of defilement in the religious consciousness in Chapter 4 of this work. Ricoeur's ensuing schema, sin, is the conscience recognizing that the bond between man and God, the concept of the Hebrew covenant, has been broken (48). The Hebrew prophets point to different types of "evil" that are sin: iniquity, which comes from a wicked heart; pride, arrogance, false greatness; and adultery (57). These sins are rewarded at times by God absenting himself which, according to Ricoeur, is "an anguish worse than suffering" (57). We see this evidenced in The Monk when, at the end of the novel, Ambrosio is called the "god-abandoned" (Lewis 437). "Does not sin make God the Wholly Other?" Ricoeur writes (58). The tension between the finite law and God's infinite commandment is essential to the consciousness of $\sin$, Ricoeur writes (59). On one hand, there is the "unconditional but formless demand that finds the root of evil in the 'heart'; on the other, a finite law that determines, makes explicit, and breaks up 
sinfulness into enumerable 'transgressions." If the dialectic between humankind and God is broken, God withdraws into the distance (62). This marks the "objective" pole of the consciousness of $\sin$.

The "subjective" pole of the consciousness of sin is actually the changing of fear and anguish rising from the consciousness of defilement to the consciousness of $\sin (63)$; a new quality of anguish results. The situation of sinful man before God is terror, reinforced by the incompatibility of man and God (63). Along these lines, guilt represents the internalization and personalization of the consciousness of sin. This traumatism of the religious consciousness must be studied within the horizon of the Covenant, Ricoeur writes (66), and this reveals a paradox: the God who is the protector, who is complicit with the people of Israel, is also the God who threatens them. As Ricoeur writes, "This threat places the Lord at a greater distance from history and shatters his historical complicity with the chosen people in the same way as the infinite demand introduced into the codes increases the ethical distance between God and man" (67). In turn, God's wrath becomes the wrath of holiness itself as opposed to wrath as a vindication of taboos. Eventually, this wrath of God will turn to sadness of love (67). However, under God's wrath and the absence of him as the Wholly Other, the "unhappy consciousness" of the sinner discovers that its separation from God is still a relation (69). "The vocative $-\mathrm{O}$ God-which expresses the invocation of the petitioner, puts the moment of rupture back within the bond of participation; if God were the Wholly Other, he would no longer be invoked," Ricoeur writes (69). In this movement of invocation, the sinner becomes the full subject of sin, while God becomes the supreme Thou (69). Ricoeur also examines the 
concept of sin as "nothingness," and relates "good" and "evil" to "God" and "nothing."

Ricoeur states:

Intention, act, consequences, punishment--it is the whole process that is $\sin . .$. . That is why this seeing, far from preventing the birth of the Self, gives rise to self-awareness; it enters into the field of subjectivity as the task of knowing oneself better; this seeing, which is, lays the foundation for the ought-to-be of self-awareness. . . my own observation of myself is the attempt of self-awareness to approximate the absolute view; I desire to know myself as I am known," Ricoeur writes (85).

However, the "realism" of sin cannot be fully understood until it is approached through "guilt," Ricoeur writes, although guilt is not synonymous with fault (100). On the contrary, reflection on guilt leads in three directions: the ethico-juridical reflection on the relation of penalty to responsibility; the religious reflection of the scrupulous conscience; and the psycho-theological reflection of the hell of the "accused and condemned" conscience (100). The consciousness of guilt, however, constitutes a revolution in the experience of evil because it illustrates evil as the evil use of liberty, felt in the "diminution of the value of the self" (102), as we shall especially see in the concept of the accused and condemned consciences of Ambrosio in The Monk. Accusation against the individual is the seat of guilt, Ricoeur writes (44).

However, that which supposedly guides us to live "right" also condemns us, and this idea leads to Ricoeur's concept of the servile will. For example, the "law" itself is a source of sin, as the apostle Paul discovered; the law, by putting "sin" in front of the people, by making knowledge of it accessible, makes people aware of it and thus makes them able to $\sin (140)$. This raises a dichotomy between "sin" and the "law"-how is it possible that the law, that which is supposed to lead humankind in the right directionalso leads to humankind's destruction? The apostle James writes: 
For sin, taking occasion by the commandment, seduced me: and by it killed me. Wherefore the law indeed is holy: and the commandment holy and just and good. Was that when which is good made death unto me? God forbid! But sin, that it may appear sin, by that which is good, wrought death in me; that $\sin$, by the commandment, might become sinful above measure. For we know that the law is spiritual. But I am carnal, sold under sin. For that which I work, I understand not. For I do not that good which I will: but the evil which I hate, that I do.... For I know that there dwelleth not in me, that is to say, in my flesh, that which is good. For to will is present in me: but to accomplish that which is good, I find not. . . . For I see another law in my members, fighting against the law of my mind and captivating me in the law of sin that is in my members. (James 7: 11-15, 18, 23, Douay-Rheims The Holy Bible 157)

Humankind is caught in this polarity between the law and sin; that which is supposed to give life - the law-actually leads to death by sin (141). This forces humankind to take the "I" of reason (the self, or consciousness) and the "I" of the flesh (the physical self) upon itself; "The flesh is myself alienated from myself, opposed to itself and projected outward," Ricoeur writes. The flesh is the powerlessness of the self whose desires are "contrary to those of the spirit" (143). This culminates in Ricoeur's concept of the "servile will," which is, in effect, the will that is a slave to its own passions which are in opposition to the Covenant between humankind and God, and which this work will show evidenced strongly in the character of Ambrosio in The Monk. The servile will, for Ricoeur, is a captive free will. "Thus the captivity of the body and even the captivity of the soul in the body are the symbol of the evil that the soul inflicts on itself, the symbol of the affection of freedom by itself; the "loosing" of the soul assures us retrospectively that its "bonds" were the bonds of desire, active-passive fascination, autocaptivity; "to be lost" means the same thing, Ricoeur states (154).

Objective sin-Consciousness in The Monk: The Self's Absenting of God as Salvation through the "Servile Will" 
If he attempted to pray, He recollected that He deserved not heaven's protection, and believed his crimes so monstrous, as to baffle even God's infinite goodness. For every other sinner, He thought there might be hope, but for him there could be none. (Lewis 422)

As Ricoeur emphasizes, God absents himself in the presence of sin and becomes the "Wholly Other." We see this evidenced strongly in The Monk, where Satan and the forces of Evil, including Matilda, are free to act as they see necessary to lead the beleaguered monk, Ambrosio, astray. At no time do God or forces of Good interfere; on the contrary, as Matilda points out, Ambrosio has set God as his foe, in essence separating himself from God through his sin and affirming Ricoeur's idea of God as the "Wholly Other." After Ambrosio sets his appetite on Antonia, Matilda offers to aid his designs by soliciting the powers of the dark forces, which Ambrosio initially refuses. Matilda accuses him of having a mind "weaker than a Woman's," and he responds, "What? Though conscious of the danger, wilfully shall I expose myself to the Seducer's arts? Shall I renounce for ever my title to salvation? Shall my eyes seek a sight, which I know will blast them? No, no, Matilda; I will not ally myself with God's Enemy" (Lewis 268-9). Matilda replies:

Are you then God's Friend at present? Have you not broken your engagements with him, renounced his service, and abandoned yourself to the impulse of your passions? Are you not planning the destruction of innocence, the ruin of a Creature, whom He formed in the mould of Angels? If not of Daemons, whose aid would you invoke to forward this laudable design? Will the Seraphims protect it, conduct Antonia to your arms, and sanction with their ministry your illicit pleasures? Absurd! (269)

While Matilda's arguments to this point in the text, and at other points in the remainder of the text, have primarily been sophist ones (which, like arguments of the ancient Greek sophists, are aimed at winning the argument as opposed to finding truth), at this point she forwards logical reasoning that, even as it denies the absolute forgiving spirit of God 
advanced in the Holy scriptures, nonetheless reinforces the binary opposition between Ambrosio's actions and his conscience, in effect acknowledging Ambrosio's servile will. Matilda also effectively summarizes Ambrosio's designs upon Antonia as unholy, and in essence affirms Ricoeur's idea of the servile will as a captive, free will: Ambrosio's will is slave to his passions, and yet he is certainly free and is thus responsible for his actions, as Aquinas, Anselm, and Augustine, in addition to the Bible, postulate.

This idea of God as the "Wholly Other," a force in opposition to the actions, if not yet the soul, of Ambrosio, is evidenced as well in Ambrosio's consciousness in The Monk, if not in conscious thought, then by the absence of God in the monk's thoughts. We are led to believe in the beginning of the text that Ambrosio is possibly the most holy man in the vicinity, and yet, immediately when we are alone with the monk, we see his true self as prideful, arrogant, and lustful. To the assembled crowd, Ambrosio speaks of the "excellence of an unsullied conscience, of the glorious prospect which Eternity presented to the Soul untainted with reproach, and of the recompense which awaited it in the regions of everlasting glory" (19). In this introductory sermon, we see Ambrosio addressing the assembly regarding the punishments of Hell and the glory of Heaven, but not specifically God himself. We might postulate that God as a single presence with the will and power to forgive any sin is not pre-eminent in Ambrosio's consciousness, but that the concepts of Heaven and Hell in the forms of punishment and reward are. In fact, throughout the text we fail to see Ambrosio pray to an eternal power for guidance of any kind; at the end of the text, when he awaits his fate at the hands of the Inquisition, his conscience-now the epitome of the accused conscience and on the brink of transforming into the "condemned conscience," as we shall examine in the last chapter of this work- 
prevents him from praying because he believes God will not forgive his sins (422). He is aware of the role of his Will in his sin:

While Reason forced him to acknowledge a God's existence, Conscience made him doubt the infinity of his goodness. He disbelieved, that a sinner like him could find mercy. He had not been deceived into error: Ignorance could furnish him no excuse. He had seen vice in her true colours; Before He committed his crimes, He had computed every scruple of their weight; and yet he had committed them. 'Pardon?' He would cry in an access of phrenzy; 'Oh! There can be none for me!' (426)

Ricoeur writes that God absents himself as the "Wholly Other." The phrase indicates God is the mover, the driver of action, the one who absents himself from the consciousness of those who sin. For Ambrosio, because there is no God to take action in the text, Ambrosio himself becomes the prime mover of his salvation or damnation. The role of the Will in relation to the Will of God-a direct binary opposition, in this instance, that is integral to Ricoeur's idea of the "servile will"- -determines Ambrosio's self-damnation as he, the prime mover, absents God and ensuing salvation from his consciousness. We will discuss this more in the final chapter of this work.

Subjective sin-Consciousness in The Monk: The Movement from the "Unhappy Conscience" to the "Accused Conscience"

But when the will turns away from the unchangeable and common good toward its own private good, or toward external or inferior things, it sins. (Augustine, On Free Choice of the Will 68)

In The Monk, we see Ambrosio become more lost as he progresses down the phenomenological path to damnation. Through a complete lack of faith in a higher being capable of salvation, he absents the being he has counted upon all of his life-Godfrom his world. As readers, we are disappointed if we anticipate salvation for the beleaguered monk. In fact, at the end of the text, we see Satan has deliberately placed 
great temptations in Ambrosio's path to deliberately lead him astray. Ambrosio's realization that his Will has played an integral role in his sins, as well as his idea that God is not all Good and will not forgive him, certainly thrusts him from the state of the "unhappy conscience" to the "accused conscience." With no forgiveness, his sins act upon his conscience as active agents designed to thrust him into Ricoeur's next step, Guilt, and the final step on the phenomenological path to damnation, Punishment, a step not thoroughly examined by Ricoeur but one which we will examine in the last chapter of this work.

As we discussed in Chapter 4, Ambrosio does not confess, which allows him to live in bad faith with his conscience; his self, although aware of its defilement, does not admit of it in the beginning of his transgressions against the Hebrew covenant, although his self becomes more aware of its defilement, sin, guilt, and ensuing punishment as his stain of defilement grows. Ambrosio's "unhappy conscience" is illustrated through the lack of success of it as an active agent to show his self a true picture of itself. For our purposes, the "unhappy conscience" engages the self in a constant struggle to achieve an authentic self, or one that does not live in Sartre's idea of "bad faith," and we see this when Ambrosio feels remorse, a direct message from the conscience, one moment but buries that feeling the next. The "unhappy conscience" transforms into the "accused conscience" when the self realizes it is not only defiled, but has transgressed the word of God, or broken the Hebrew covenant, and thus "sinned."

Ambrosio's movement from the "unhappy conscience" to the "accused conscience" is best illustrated through an analysis of sin-consciousness in The Monk. ${ }^{2}$ The accused conscience is born from what the self deems as the all-seeing, condemning 
eye of God; the accusation comes in the form of the broken covenant with God. The self wants to know itself as it is known to God; the sinner wants to see himself as God knows him, according to Ricoeur. However, this is impossible because humans do not have God consciousness. Humans have only the "word" of God, filled with symbols and metaphors, to rely upon to "see" themselves as God would see them. This is the birth of the "accused conscience," where the self misleads itself. However, the image the conscience holds of the self as it should be may not be the image God has of it. This results in a hostile selfview associated with God's omniscient consciousness. In other words, the sinner believes - perhaps inauthentically - that God has condemned him when, in fact, salvation is always possible, according to scripture, as we shall examine in the last chapter of this work. For the accused conscience, the conscience is an active agent that finally succeeds, in part, at presenting a true self-picture to the self, and the reaction is one of horror, as we see immediately after Ambrosio has murdered Elvira: "No ideas offered themselves to his mind but those of death and guilt, of present shame and future punishment. . . Bewildered by fear, He fancied that his flight was opposed by Legions of Phantoms; ... $\mathrm{He}$ abandoned his soul to the tortures of unavailing remorse, and terrors of impending detection" (Lewis 304-5). Note here that the image of God Ambrosio holds is one of the Divine Punisher, as opposed to a divine instrument of salvation. This may be the result of Ambrosio's lack of faith in a higher power capable and willing to forgive his transgressions and restore him to a state of Grace. To establish this association, we must first examine, through scripture and primary medieval religious philosophers, how we "see" and "know" God as a divine being whose willingness to forgive has no boundsthis is the idea of faith that would have been known to the ideal-type religious 
consciousness, which we have equated with Ambrosio's religious consciousness. We can then apply these principles to an examination of how Ambrosio perceives God in his consciousness.

According to Anselm of Canterbury, to know God one must have faith. We begin our journey toward actualizing faith by engaging in love for and belief in the Supreme Essence, or God. "No soul is unjustly deprived of the supreme good. The supreme good ought to be the object of our total commitment and exertion," Anselm writes ("Monologion" 77). In addition, Anselm writes, believing in the supreme good, or God, "paves the human soul's way to the supreme essence; by believing, we progress towards the supreme essence" (78). This idea of faith as a bridge between humankind and God is

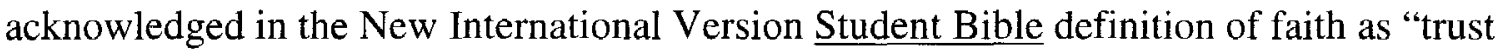
and reliance on God" (1413). Biblical scripture is rife with the idea of faith and its importance in salvation from sin:

But now, without the law, the justice of God is made manifest, being witnessed by the law and the prophets. Even the justice of God, by faith of Jesus Christ, unto all, and upon all them that believe in him: for there is no distinction. For all have sinned and do need the glory of God. Being justified freely by his grace, through the redemption that is in Christ Jesus. Whom God hath proposed to be a propitiation, through faith in his blood, to the shewing of his justice, for the remission of former sins. Through the forbearance of God, for the shewing of his justice in this time: that he himself may be just and the justifier of him who is of the faith of Christ Jesus. Where then is thy boasting? It is excluded. By what law? Of works? No, but by the law of faith. (Romans 3:21-28, Douay-Rheims The Holy Bible 153-4)

In addition, Ephesians 3:12 states, "In whom we have boldness and access with confidence by the faith of him," and Hebrews 10:22 specifies, "Let us draw near with a true heart, in fullness of faith, having our hearts sprinkled from an evil conscience and our bodies washed with clean water. Let us hold fast the confession of our hope without 
wavering (for he is faithful that hath promised)" (Douay-Rheims 228) Without faith, the supreme bridge between humankind and God, there is no salvation because the only way we can know God is through faith. It is important to note here, however, that the idea of knowing God through faith is equated with knowing God as the supreme giver of salvation in addition to the giver of punishment. We have no access to divine "Grace," defined as "the undeserved love and salvation God gives," (Student Bible) without first having faith that God will grant mercy and forgive sin.

Yet, as scripture maintains, there is no true faith without accompanying deeds.

The apostle James states:

What shall it profit, my brethren, if a man say he hath faith, but hath not works? Shall faith be able to save him? ... Thou believest that there is one God. Thou dost well: the devils also believe and tremble. But wilt thou know, O vain man, that faith without works is dead? . . For even as the body without spirit is dead: so also faith without works is dead. (James 2: 14, 19, 26, Douay-Rheims The Holy Bible 234)

Ambrosio's actions throughout the text-certainly not actions of love-illustrate his faith, in essence, is waning, if not dead, as Lewis's plot progresses. It seems the more Ambrosio absents God as Salvation from his consciousness, triggered by his continuing acts contrary to love and forgiveness, the stronger the image of God the Divine Punisher becomes. When confronted with the opportunity to extend grace and forgiveness to Agnes, Ambrosio responds harshly: "Mercy here would be criminal. You have abandoned yourself to a Seducer's lust; You have defiled the sacred habit by your impurity; and still dare you think yourself deserving my compassion?" he responds (Lewis 46). We find what appears to be an act of mercy-his willingness to leave the abbey to attend to Elvira - is a farce designed to effect the ruin of Antonia. "At first bounded his wishes to inspire Antonia with friendship: But no sooner was He convinced 
that She felt that sentiment in its fullest extent, than his aim became more decided, and his attentions assumed a warmer colour," Lewis's narrator tells us (256). However, Lewis's narrator also maintains the monk is not without pity for Antonia, the victim of his desires:

She gave up all hopes of escaping the Sepulchre with life. Yet in harbouring this idea, She did him injustice. Amidst the horror and disgust to which his soul was prey, pity for his Victim still held a place in it. The storm of passion once over, He would have given worlds had He possest them, to have restored to her that innocence, of which his unbridled lust had deprived her. Of the desires which had urged him to the crime, no trace was left in his bosom: the wealth of India would not have tempted him to a second enjoyment of her person. His nature seemed to revolt at the idea, and fain would He have wiped from his memory the scene which had just past. As his gloomy rage abated, in proportion did his compassion augment for Antonia. (386)

In the midst of his pity, however, we are immediately confronted with another image of God the Divine Punisher: "To one so laden with crimes, Death came armed with double terrors," Lewis writes (386-7). The brief showing of Ambrosio's conscience-the guilt he feels because of his ruin of Antonia's innocence-is countered by his self-portrait of God as Divine Punisher. By the end of Lewis's text, Ambrosio holds no belief in God as the divine instrument of salvation, but only as the Divine Punisher-a perfect symbol of the death of his faith. It is important here to establish this because without this unshakable belief in a supreme forgiver, Ambrosio dooms himself before he relegates his soul to Satan at the end of The Monk.

Ambrosio's final struggle between his faith and Satan—reminiscent of the faith struggles of Hawthorne's character, Young Goodman Brown, and Marlowe's Dr. Faustus-culminates in the chaotic death of his faith. He refuses to sign Satan's contract the first time the demon presents it: "Infinite is the Almighty's mercy, and the Penitent shall meet his forgiveness. My crimes are monstrous, but I will not despair of pardon: 
Haply, when they have received due chastisement ...." (434). This resurgence of faith in God as Divine Salvation-an image of God we rarely see in Ambrosio's consciousness throughout the text-is immediately squelched by Satan's counter-argument:

Chastisement? Was Purgatory meant for guilt like yours? Hope you that your offences shall be bought off by prayers of superstitious dotards and droning Monks? Ambrosio, be wise! Mine you must be: You are doomed to flames, but may shun them for the present. (434)

Ambrosio resists the demon with cries of, "Leave me! Begone! I will not sign the Parchment," and Satan departs furiously with, "Go then! Rave in agony, expire in tortures, and then learn the extent of the Eternal's mercy!" (435). After Satan disappears, Ambrosio at first relishes in his victory, but soon again succumbs to the image of God the Divine Punisher:

But as the hour of punishment drew near, his former terrors revived in his heart. Their momentary repose seemed to have given them fresh vigour. The nearer that the time approached, the more did He dread appearing before the Throne of God. He shuddered to think how soon He must be plunged into eternity; How soon meet the eyes of his Creator, whom He had so grievously offended (436).

Soon, Ambrosio shoves his conscience to the background as he reads from the text, "as if fearing to allow himself a moment's thought," to call Satan a second time (436). He signs his soul to Satan, the death of his faith embodied in Lewis's phrase, "Take it! Said the God-abandoned; 'Now then save me! Snatch me from hence!”' (437) Ambrosio's ensuing actions mark the progression of his conscience from the "accused conscience" to the "damned conscience," as we shall examine in the last chapter of this work.

The Intersubjective Constitution of Sin in The Monk

Think upon your crimes! Think upon your lust, your perjury, inhumanity, and hypocrisy! Think upon the innocent blood, which cries to the Throne of God for vengeance, and then 
hope for mercy! Then dream of heaven, and sigh for worlds of light, and realms of peace and pleasure! Absurd! Open your eyes, Ambrosio, and be prudent. (Lewis 429)

Augustine mentions that when the will turns away from divine good and toward physical pleasures as opposed to spiritual ones, it sins (68). We are aware of Ambrosio's consciousness of his sins through his physical life as opposed to his mental life, although his physical actions are a mirror for his consciousness after he sins. For example, he turns away from Matilda in shame when he first transgresses sexually with her; this certainly implies he knows he has committed a transgression from the holy covenant, an act for which he feels ashamed and defiled. However, Ambrosio seems blissfully unaware that his lust after the portrait of the Virgin Mary (the image of Matilda) in his chamber is a sin as well. This implies that sin exists only in the physical lifeworld for Ambrosio, as opposed to the mental lifeworld. While this is contrary to scripture-in Matthew 5:27-8, Jesus says, "You have heard that it was said to them of old: Thou shalt not commit adultery. But I say to you that whosoever shall look on a woman to lust after her hath already committed adultery with her in his heart" (Douay-Rheims The Holy Bible 5) - it is integral to our analysis of Ambrosio's consciousness of sin. For Ambrosio, it is his physical actions-specifically his acts of murder - that will damn him, and it is these that drive him from the "unhappy conscience" to the "accused conscience" and eventually the "condemned conscience" which is born when his self finally acknowledges the image his conscience has been holding for him. His murder of Elvira is his first physical action that vaults him from the unhappy conscience to the accused conscience; although he seems able to push the thought of this sin from his mind, it and his ensuing murder of Antonia return to haunt him as he is in his cell, awaiting the Inquisition. When he dozes, he dreams of the ghosts of Elvira and Antonia who reproach 
him with their deaths and urge the daemons to "inflict torments of cruelty yet more refined," symbolic of the guilt he appropriates after their murders (427). Ambrosio creates a plan for penance based upon holding Antonia prisoner in the underground sepulcher for the remainder of her life, with him attending to her daily and begging her forgiveness, but he, in direct reaction to the mob about to force its way into the sepulcher, destroys his instrument of salvation in a physical act symbolic of the death of his selfforgiveness essential to securing the Grace of God. With no solid image of God as instrument of forgiveness and salvation and the destruction of Antonia, his physical image of forgiveness and salvation, Ambrosio solidifies his internal movement from the unhappy conscience to the accused conscience and eventually seals his doom through the "condemned conscience."

However, it is important to note here that Ambrosio's idea of sin and its forgiveness, in Lewis's text, are not intersubjectively constituted through holy scripture and religious philosophers alone. While the ideal-type religious consciousness would have been aware of God's Grace and how to secure it, it would be less than fair to point an accusing finger at Ambrosio's self and conscience without admitting the influence of the dark forces upon his thoughts. It is Matilda who first lures him into physical transgression from God's covenant: "Unnatural were your vows of Celibacy; Man was not created for such a state; And were Love a crime, God never would have made it so sweet, so irresistible!" she exclaims after their initial tryst (224). We see the immediate effect on Ambrosio's consciousness: "The die was thrown: His vows were already broken; he had already committed the crime, and why should He refrain from enjoying its reward?" (224) As we have discussed earlier in this work, Ambrosio's false 
intersubjective constitution with the characters and symbols around him leads to his life of "bad faith," or inauthenticity, where his conscience unceasingly struggles to present an accurate picture of his self. Here, Matilda attempts to persuade him that their act of "love" cannot fall within the realm of sin because of its inherent physical goodness, and while Ambrosio obviously acknowledges the "crime" he has just committed, Matilda's arguments allow him to thrust it aside and endeavor to rely upon his waning faith in God as Supreme Salvation for forgiveness. His efforts obviously fail.

In addition, Matilda - and eventually Satan-play an integral role in the death of Ambrosio's faith and thus salvation through the Grace of God. Matilda appears to the monk in his cell, apparently free of the chains of the Inquisition, and urges him to partake of the opportunity she had to secure her immediate physical salvation:

Our mutual guilt and danger have rendered you dearer to me, than ever and I would fain save you from impending destruction. Summon then your resolution to your aid; and renounce your immediate and certain benefits the hopes of a salvation, difficult to obtain, and perhaps altogether erroneous. Shake off the prejudice of vulgar souls; Abandon a God, who has abandoned you, and raise yourself to the level of superior Beings! . . Still dare you hope for pardon? Still are you beguiled with visions of salvation? Think upon your crimes! Think upon your lust, your perjury, inhumanity, and hypocrisy! Think upon the innocent blood, which cries to the Throne of God for vengeance, and then hope for mercy! Then dream of heaven, and sigh for worlds of light, and realms of peace and pleasure! Absurd! Open your eyes, Ambrosio, and be prudent. Hell is your lot; You are doomed to eternal perdition; Nought lies beyond your grave, but a gulf of devouring flames. And will you then speed towards that Hell? Will you clasp that perdition in your arms, ere 'tis needful? Will you plunge into those flames, while you still have the power to shun them? 'Tis a Madman's action. . . . Let us for awhile fly from divine vengeance." (429-30)

Matilda's portraiture of God as Divine Punishment - certainly indicative of Ambrosio's consciousness of God-is almost identical to the image portrayed by Satan at the end of the text as the monk slays his faith and signs his soul to the Eternal Tormenter. These arguments, while convincing to Ambrosio and helping to thrust him to the Guilt and 
Punishment step on his phenomenological path to damnation, were not necessarily true, as we shall examine in the last chapter of this work. 


\section{Endnotes}

1 For a more detailed analysis of Blake's art and life, please see Mary Lynn Johnson and John E. Grant's Blake's Poetry and Designs, New York: W.W. Norton, 2008, and Martin Myrone's The Blake Book, London: Tate Pub., 2007.

2 Ricoeur specifies an "accused and condemned conscience." However, I separate those traits of conscience as specific steps on the phenomenological path to damnation of the self for Ambrosio. In addition, in the last chapter of this work, we will examine the "condemned conscience" as separate from the "accused conscience." 


\section{CHAPTER VI: SIN-INTERNALIZATION AS GUILT AND PUNISHMENT: MOVEMENT FROM THE "ACCUSED CONSCIENCE" TO THE “CONDEMNED” AND "DAMNED" CONSCIENCES AS THE CULMINATION OF THE PHENOMENOLOGICAL PATH TO DAMNATION IN THE MONK}

Worked up to phrenzy by the urgent danger, shrinking from the approach of death, terrified by the Daemon's threats, and seeing no other means to escape destruction, the wretched Monk complied. He signed the fatal contract, and gave it hastily into the evil Spirit's hands, whose eyes, as He received the gift, glared with malicious rapture. (Lewis 437)

In Chapter 5, we examined Ambrosio's movement from Ricoeur's idea of the "unhappy conscience" to the "accused conscience," and we separated Ricoeur's idea of the "accused and condemned conscience" in order to analyze each in turn on Ambrosio's phenomenological path to damnation. Now we progress to the culmination of Ambrosio's self-damnation in consciousness with his movement from the "accused conscience" to the "condemned conscience" and eventually the "damned conscience," which will represent the final movement from Ricoeur's notion of guilt to the idea of punishment, a concept Ricoeur does not specifically explore in The Symbolism of Evil. This final step into Ambrosio's damnation in his physical and mental lifeworlds illustrates the idea of the conscience as an active agent striving to portray a true image of Ambrosio's self to his self, while the self continues to resist this truth as it exists in Sartre's idea of "bad faith." However, the culmination of Ambrosio's doom occurs when he embraces the truth of his existence, even as his self casts aside notions of forgiveness, in light of his dying and eventually dead faith and his agency in casting God aside not as the "Wholly Other," but 
as the "Mythical Other," a term we shall soon examine in relation to the idea that in Ambrosio's consciousness, God becomes a mythological agent who exists in the mental lifeworld only. Ambrosio's movement is the opposite of Christ's descent into death and ultimate return to Heaven; it is also the embodiment of an anti-Platonic descent in his thrusting aside of knowledge of Faith and Salvation to delve head-first (literally, in his fall off the mountain at the end of the text) into ignorance and damnation. It is important to note here that we do not address guilt, punishment, and damnation as individual entities in this final chapter because the interplay of these signifiers at this point is so permeable that it becomes nearly impossible to distinguish them, as we have on previous steps of the path. These are not experienced singly but as a whole. We begin our examination of Ambrosio's final descent into his self-sentenced Hell with a look into notions of damnation in gothic literature and art.

The Notion of Guilt and Punishment in Gothic Art and Literature

Thou hast enjoyed no moment of peace, nor even the smallest of those fruits for which thou wast reduced so deeply to sin! Thus hath my triumph been richly compleated, thou art at once betrayed and cursed! and the glory of thy utter destruction is mine! (Dacre 267)

Gothic literature is rife with examples of character guilt and punishment. We have seen Victor in Mary Shelley's Frankenstein (1818) scurrying across a vast expanse of arctic ice in chase of his creature, a representation of his guilt and the instrument of his mental and physical punishment, earlier in this work. We have seen the black cat as the protagonist and symbol of guilt and its physical effect in the form of a cat hanging from a gallows in Edgar Allen Poe's infamous tale, "The Black Cat." However, Victoria in Charlotte Dacre's Zofloya: Or The Moor (1806) is perhaps the closest parallel to 
Ambrosio in The Monk. In fact, the influence of Lewis is evident in Dacre's work. Victoria, a young, strong-willed woman, affects her own demise when she murders her own husband to secure the love of her husband's brother, with the aid of Zofloya, who is actually Satan, disguised as a mortal. Against Zofloya's counsel, Victoria insists on giving her husband a faster-acting poison than the one Zofloya originally gives her and brings about her own demise as she scrambles to hide her actions. At the end of the text, we see Victoria living in "bad faith" much like Ambrosio as she blames her mother, who deserted she and her brother when they were children, for her own fate, although her brother, Leonardo, is quick to point out her own blame for her actions: "Nor wholly on her, abandoned girl, dare to affix thy guilt and crimes—-far, far beyond what her example ever taught thee. No, Victoria, thy base mind was naturally evil;--a mother's example might have checked thy depravity, but could never have rendered thee virtuous!' (Dacre 259) ${ }^{1}$ Unlike Ambrosio, Victoria experiences no guilt for her actions throughout Zofloya: Or the Moor. In a Lewis-like plot twist, Satan hurls Victoria from the top of a steep mountain into the waters below. Immediately afterward, Dacre's narrator steps forward:

Reader - consider this not a romance merely. Over their passions and their weaknesses, mortals cannot keep a curb too strong. The progress of vice is gradual and imperceptible, and the arch enemy ever waits to take advantage of the failings of mankind, whose destruction is his glory! That his seductions may prevail, we dare not doubt; for can we otherwise account for those crimes, dreadful and repugnant to nature, which human beings are sometimes tempted to commit? Either we must suppose that the love of evil is born with us (which would be an insult to the Deity), or we must attribute them (as appears more consonant with reason) to the suggestions of infernal influence. (268)

It is important to note here, however, that although Satan encourages Victoria's actions, per our discussions of the role of the Will and Satan in sin in Chapter 5 of this work, it is Victoria's Will that ensures her damnation. ${ }^{2}$ 
The theme of damnation is also explored in H.G. Wells's gothic novel, The Island of Dr. Moreau, through the concepts of pleasure and pain; here, the deliberate delivery of pain to a creature capable of feeling it is instrumental in the doom of Dr. Moreau. In this text, Dr. Moreau thrusts aside moral values in favor of a science with no specific purpose. Moreau explains to Prendick:

Then I am a religious man, Prendick, as every sane man must be. It may be I fancy I have seen more of the ways of this world's Maker than you-for I have sought his laws, in my way, all my life, while you, I understand, have been collecting butterflies. And I tell you, pleasure and pain have nothing to do with heaven and hell. Pleasure and pain--Bah! What is our theologian's ecstasy but Mahommet's houri in the dark? This store men and women set on pleasure and pain, Prendick, is the mark of the beast upon them, the mark of the beast from which they came. Pain! Pain and pleasure-they are for us, only so long as we wriggle in the dust. (Wells 55)

Although Wells leaves us wondering about Moreau's spiritual damnation, at the culmination of Wells's text we see the physical damnation of Moreau symbolized in his battered and broken body lying in the bushes by the sea, with his spiritual doom illustrated through his final chase through the woods, the animal-space in the text. However, we have little doubt about the spiritual damnation of Prendick, who was an unwilling participant in Moreau's crimes. After Moreau and Montgomery are dead, Prendick is left alone among the beast people, reminiscent of a horde of demons as they torment and challenge him. Prendick's physical changes mirror his spiritual decline: "My clothes hung about me as yellow rags, through whose rents glowed the tanned skin. My hair grew long, and became matted together. I am told that even now my eyes have a strange brightness, a swift alertness of movement" (98). In The Monk, we see Ambrosio, like Prendick, begin to mirror the actions of demonic agents as he vents his despair in blasphemy, curses, and wails. 
Of all works of literature, however, it is Dante Alighieri's The Divine Comedy (c. 1321) that perhaps best examines the damnation/salvation dichotomy and, as we shall examine in the next section of this work, the idea of Christ as the active and yet passive agent in that dichotomy. In the first rung of Dante's "Book I: Inferno," we find the "virtuous pagans," those who lived virtuous and pious lives before Christ's term on earth. Because these people—including Socrates, Plato, and Aristotle—could not have known Christ and sought him as the mediator between the dichotomy of God as Salvation and God as Punishment, they are doomed to eternity in this place in Hell. The realm of the virtuous pagans is beautiful and pleasant, and yet an overriding hopelessness pervades it because the virtuous pagans will never gain access to Heaven, as the Roman poet Virgil explains to Dante:

So he entered and so he led me in / to the first circle and ledge of the abyss. / No tortured wailing rose to greet us here/ but sounds of sighing rose from every side, / sending a tremor through the timeless air, / a grief breathed out of untormented sadness, / the passive state of those who dwelleth apart, / men, women, children - / a dim and endless congress. / And the Master said to me: "You do not question/ what souls these are that suffer here between you? / I wish you to know before you travel on / that these were sinless. And still their merits fail, / for they lacked Baptism's grace, which is the door / of the true faith you were born to. Their birth fell / before the age of the Christian mysteries, / and so they did not worship God's Trinity / in fullest duty. I am one of these. (Dante 39) 
The Hell in which the virtuous pagans reside is one they possibly created through their own visions of an afterlife; for example, Socrates is in this Limbo, discussing philosophy with some of the greatest pre-Christian Figure 9: "The Sleep of Reason Produces minds in history. For Dante, good works in life have meaning, but open baptism and the Grace of God through Christ are essential for salvation. We shall explore this notion of Christ as the mediator between God and humankind in the next section of this work.

In gothic art, Francisco de Goya's “The Sleep of Reason Produces Monsters" (1797-98) certainly illustrates concepts of punishment and damnation. The victim, proposed to be Goya Monsters"

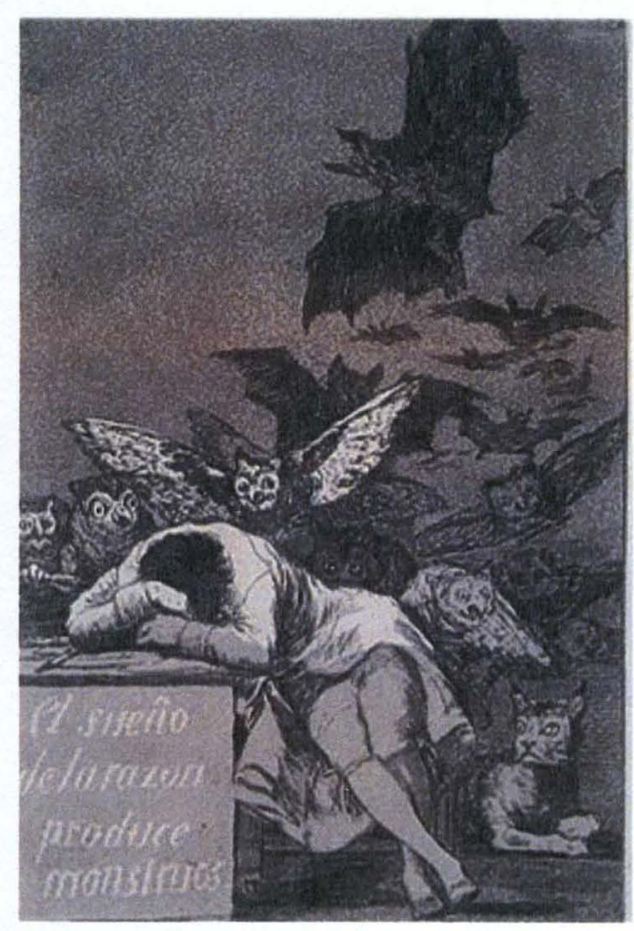
himself, sits at a writing desk, appearing to have dozed; while his imagination is free, he is attacked by disproportioned, demonic-like creatures such as a huge black bat, a winged owl on his back, and an oversized cat lying behind his chair (Herbert F. Johnson Museum of Art, par 1). The work effectively illustrates the self-damnation resulting from the suspension of reason. This is reminiscent of the controversy surrounding the ramifications of the word "imagination" in political circles in England in the mid-1790s, as discussed in Chapter 1 of this work.

In addition, we shall soon examine the idea of "despair" as specified in the writings of Aquinas and philosopher Soren Kierkegaard (1813-1855), which is integral to Ambrosio's self-damnation in consciousness, and this idea is perfectly illustrated in The 


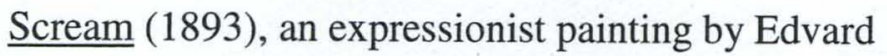

Munch (right). The unknown person in The Scream is a less-than-person, a morbid shell of humanity subject to a myriad of meaningless impressions that leave the subject venting a scream of despair regarding meaning in life. Although this painting is expressionist and is not usually equated with gothic art, it encompasses many gothic elements, such as high emotion, but especially terror and the metonymy of gloom and horror. The Scream is simply one example of how gothic art and literature have been especially amenable to psychoanalytical readings, especially Freudian and Jungian. With this in mind, we move on to a brief examination of Satan as the symbol of doom in gothic art.

At the end of The Monk, Satan reveals to Ambrosio exactly how he has deceived the monk into sinning past the point where Ambrosio can conceive of salvation for himself; thus, we see Satan as a primary instrument of Ambrosio's false intersubjective constitution, or shaping and defining of his self, that helps vault Ambrosio from the "condemned conscience" to the "damned conscience." We see similar patterns of
Figure 10: "The Scream"

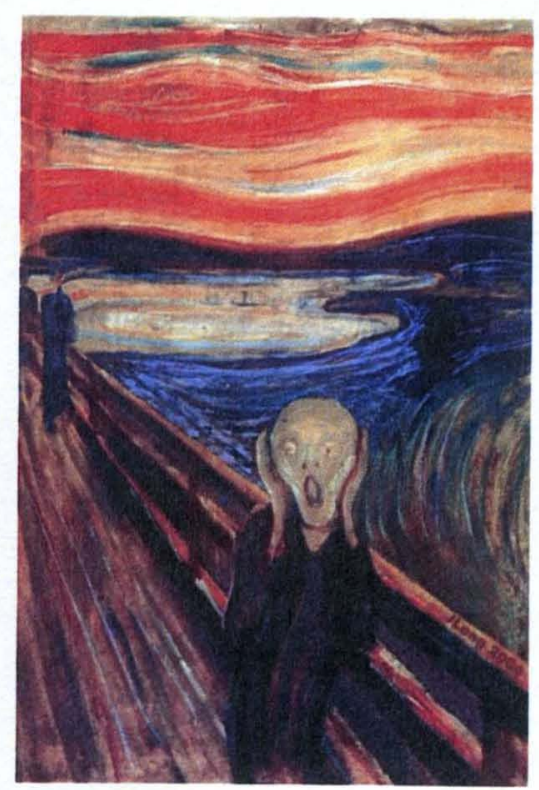

Figure 11: "Lucifer and the Pope in Hell"

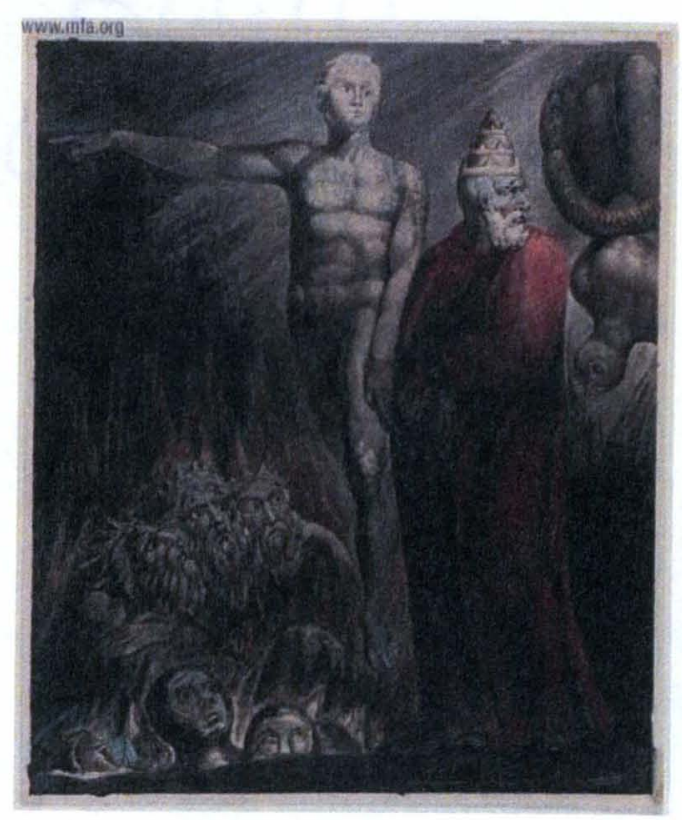


meaning in the works of William Blake (1757-1827) and Henry Fuseli (1741-1825), where Satan assumes an instrumental role in the fate of humankind. In Blake's "Lucifer and the Pope in Hell" (1795_above, Paley plate 34), we see a very humanlike Satan pointing out where the Pope's place is in Hell, while the Pope looks at what he has left behind. Satan is levitating, illustrating his supernatural powers, and dominates over other souls trapped in Hell. Obviously this painting questions the good and "truth" of the church as well as the role of humankind in the universe; like Ambrosio, the fallen Figure 12: "Satan's First Address to Eve" monk, the Pope has succumbed to evil, and God will not rescue him.

\section{Henry Fuseli’s “Satan’s First}

Address to Eve" (1802, Tomoroy plate X) again depicts Satan as not only interfering with the affairs of humankind, but also as having human features. Satan appears as a huge serpent wrapped around a tree who stares at a naked Eve. Eve has her arm up as if Satan has caught her by surprise, and yet

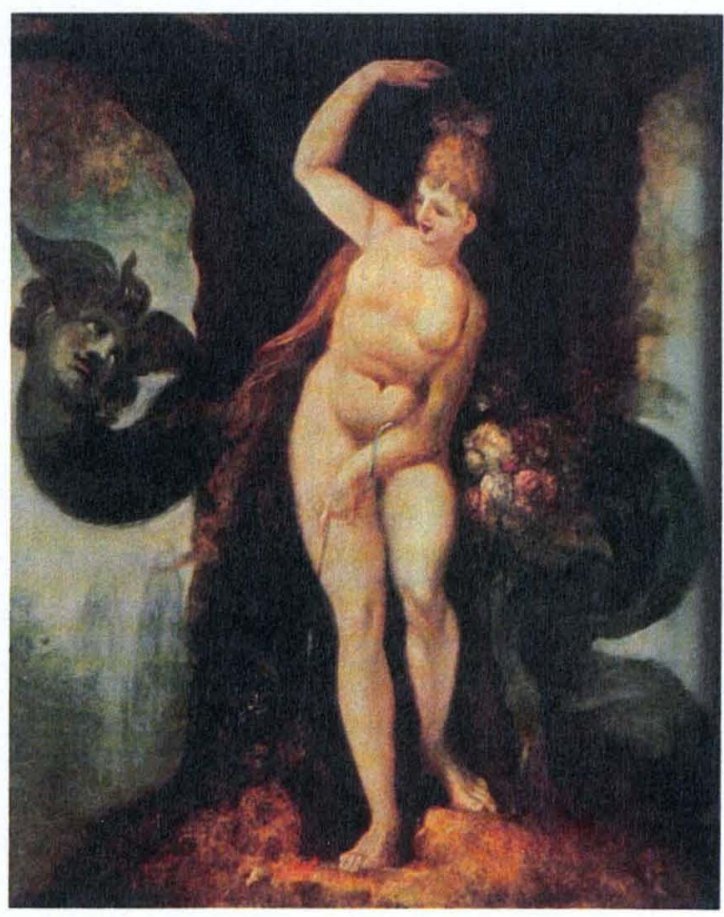
she does not seem to fear him. Who would fear something so human, even beautiful? And yet, as discussed in Chapter 2 of this work, it is Satan and Eve who arguably are primarily responsible for the fall of humankind from grace. 
The Dichotomy of Guilt/Punishment and Redemption/Salvation in Religious

Philosophical Doctrine and Scripture

So I say to you, there shall be joy before the angels of God upon one sinner doing penance. (Douay-Rheims The Holy Bible, St. Luke 15:10)

It is nearly impossible to discuss guilt/punishment without examining its opposite, redemption/salvation. For example, as discussed earlier in this work, Agnes secures redemption/salvation through her physical and mental labors when she is imprisoned in the sepulcher under the Convent of St. Clair; Ambrosio, on the other hand, achieves no such redemption or salvation. Guilt/punishment can also be viewed as a lack of redemption/salvation if examined through the philosophy of Socrates, who maintained people will naturally adhere to proper thought and conduct, or virtuous behavior, if they are acquainted with it. Augustine follows a similar philosophy by mandating that evil is simply misdirected love because love should be directed toward God (Moore 288). Lack of knowledge of redemption/salvation would certainly catapult one toward damnation, but Ambrosio, possessing the ideal-type religious consciousness, would have had indepth knowledge of how to achieve salvation. Instead, as we discussed in chapter 5, Ambrosio's dying faith catapults him down the phenomenological path to damnation, for without faith, Ambrosio has no acquaintance with God as Salvation, and instead views God as Punishment.

The concept of God as Salvation is rampant throughout the New Testament of The Holy Bible, in contrast to the image of God as Punishment prevalent in the Old Testament. Ambrosio's experience of God as Punishment, as discussed in chapter 5, is a primary attribute of his self-damnation, even as he retains his knowledge of how to achieve salvation: "Infinite is the Almighty's mercy, and the Penitent shall meet his 
forgiveness. My crimes are monstrous, but I will not despair of pardon: Haply, when they have received due chastisement..." Ambrosio asserts to Satan (434). Satan, however, as an instrument of deliberate false intersubjective-constitution, replies, "Was Purgatory meant for guilt like yours? ... Ambrosio, be wise! Mine you must be: You are doomed to flames, but you may shun them for present" (434). Ambrosio's embracing of this false image seals his fate in his consciousness, and yet, as we shall see, his idea of salvation was correct. In effect, Ambrosio's self has thrust God aside and absented him as the "Mythological Other" because of his dying faith; by thrusting God as Salvation from his consciousness, Ambrosio relegates the Almighty—now a mythological figure through which salvation cannot be attained- to a mere notion in his imagination.

The idea of God as Punishment is one Aquinas furthers in Summa Theologica. Aquinas maintains in "Question 87: The debt of punishment" that sin is an inordinate act that rises against the natural order established by God, and whoever sins commits an offense against that order, "wherefore he is put down, in consequence, by that same order, which repression is punishment" (par. 5). The human will is subject to three orders, according to Aquinas: the order of his own reason; the order of another man who governs him in spiritual or worldly matters as a member of his household or government; and the "universal order of the Divine government" (par. 6). Each order is disturbed by sin; as a result, the sinner incurs "threefold punishment: one, inflicted by himself, viz. remorse of conscience; another, inflected by man; and a third, inflicted by God" (par. 6). We see Ambrosio's "accused conscience" as an active agent when Lewis's narrator remarks, "While Reason forced him to acknowledge a God's existence, Conscience made him doubt the infinity of his goodness" (Lewis 426). 
However, it is Aquinas's idea of "Despair," similar, in ways, to Kierkegaard's idea of despair, that drives Ambrosio from the accused conscience to the condemned and damned conscience. The latin word for despair, desperare, translates into, "to be hopeless," according to The Catholic Encyclopedia, which further defines "despair":

Despair, ethically regarded, is the voluntary and complete abandonment of all hope of saving one's soul and of having the means required for that end. It is not a passive state of mind: on the contrary it involves a positive act of the will by which a person deliberately gives over any expectation of ever reaching eternal life. There is presupposed an intervention of the intellect in virtue of which one comes to decide definitely that salvation is impossible. This last is motivated by the persuasion either that the individual's sins are too great to be forgiven or that it is too hard for human nature to cooperate with the grace of God or that Almighty God is unwilling to aid the weakness or pardon the offenses of his creatures, etc. (Catholic Encyclopedia par 1)

This sin of despair is not to be confused with the idea that some people worry about their place in the afterlife. According to Catholic doctrine, this despair is a mortal sin because it thrusts aside the specific attributes of God that lead to salvation as opposed to damnation (Catholic Encyclopedia). It effectively bars the way to escape from sin, and those who suffer from despair often indulge freely in other sins. For Ambrosio, despair is an all-encompassing melding of self and conscience that hurtles him from the accused conscience to the condemned conscience and the ensuing damned conscience. Lewis's narrator tells us Ambrosio sees "no other means to escape destruction" than to sign the contract Satan presents to him; because he has abandoned all hope of salvation, Ambrosio suffers from despair before he even signs the contract.

This idea of despair is very much akin to Kierkegaard's. For the philosopher, despair is born from the endless choices individuals face alone, as individuals; "It is the result of the individual's having to make, for himself and alone, choices of lasting 
significance," Moore and Bruder write (167). For Kierkegaard, despair is the "sicknessunto-death":

There is so much talk about wasting a life, but only that person's life was wasted who went on living so deceived by life's joys or its sorrows that he never became decisively and eternally conscious as spirit, as self or, what amounts to the same thing, never became aware and in the deepest sense never gained the impression that there is a God and that "he," he himself, his self, exists before this God-an infinite benefaction that is never gained except through despair. . . I think that I could weep an eternity over such wretchedness! And to me an even more horrible expression of this most terrible sickness and misery is that it is hidden - not only that the person suffering from it may wish to hide it and may succeed, not only that it can so live in a man that no one, no one detects it, no, but also that it can be so hidden in a man that he himself is not aware of it! And when the hourglass has run out, the hourglass of temporality, when the noise of secular life has grown silent and its restless or ineffectual activism has come to an end, when everything around you is still, as it is in eternity, then-- . . eternity asks you ... whether you have despaired in such a way that you did not realize you were in despair, or in such a way that you covertly carried this sickness inside of you as your gnawing secret, as a fruit of sinful love under your heart, or in such a way that you, a terror to others, raged in despair. And if so, if you have lived in despair, then, regardless of whatever else you won or lost, everything is lost for you, eternity does not acknowledge you, it never knew you—or, still more terrible, it knows you as you are known and it binds you to yourself in despair. (Kierkegaard 679)

The only path to salvation is through a complete commitment to God,

Kierkegaard maintains (Moore 167), an idea akin to Aquinas's idea that despair effectively bars one from salvation. In fact, the answer to salvation is Christ, who descended into hell "because He came to bear our penalty in order to free us from penalty," Aquinas writes ("Question 52" par 5); "Christ's Passion was a kind of universal cause of men's salvation, both of the living and of the dead," he continues (par 7). Christ is the mediator between God and Man in his role as instrument of salvation; "Although it belongs to Christ as God to take away sin authoritatively, yet it belongs to Him, as man, to satisfy for the sin of the human race. And in this sense He is called the Mediator of 
God and men," Aquinas writes ("Question 26" par 17). The Grace of God, available through Christ, secures salvation for humankind.

Here we must make an interesting distinction regarding our idea of Ambrosio as the ideal-type religious consciousness and religious doctrine he should know as the idealtype religious consciousness. Christ as Salvation (in binary opposition to God as Punishment) is absent from Ambrosio's literal consciousness in the text, and yet, because we have equated Ambrosio's consciousness with the ideal-type religious consciousness, we must assume Ambrosio has an intimate knowledge of Christ's role in salvation. Christ is mentioned in Lewis's text primarily in the context of the Wandering Jew. According to Emma McEvoy, the Wandering Jew spit upon Christ as he was carrying his cross to Calvary and thus endured punishment as an immortal: "Fate obliges me to be constantly in movement: I am not permitted to pass more than a fortnight in the same place," the Wandering Jew says (Lewis 169). Raymond describes the Wandering Jew as a man of "majestic presence" with a strongly marked countenance, but "there was something in his look, which the moment that I saw him, inspired me with a secret awe, not to say horror" (168). The Wandering Jew is the only entity that can force the ghost of the Bleeding Nun to explain why she is present at Raymond's side; the Wandering Jew is the only human who can evince salvation in The Monk, and, like Christ, he is a blend of human and otherworldly entity. Ambrosio, who, as the ideal-type religious consciousness, should have been aware of the role of Christ in salvation, fails to mention the godhead even when he refutes Satan: "Infinite is the Almighty's mercy," Ambrosio exclaims (434). Here, it is implied that "Almighty" refers to God because, as Aquinas writes, Christ is the intermediary between God and Man. Yet, 1 Timothy 2:3-6 states: "For this is good and 
acceptable in the sight of God our Saviour, Who will have all men to be saved and to come to the knowledge of the truth. For there is one God: and one mediator of God and men, the man Christ Jesus Who gave himself a redemption for all, a testimony in due times" (Douay-Rheims The Holy Bible 213). At no time in Lewis's text does Ambrosio seek Christ as a means to salvation, although it is explicit in scripture and religious philosophy that Christ is the key to salvation. This produces a conundrum, an ideal-type religious consciousness that is unaware or deliberately ignores the specified key to salvation. Because Ambrosio would have been aware of the path to salvation, we can only assume he disregards the idea of salvation through Christ, and thus Christ, because of the despair described by Aquinas and Kierkegaard. According to St. John 14: 6-7: "Jesus saith to him: I am the way, and the truth, and the life. No man cometh to the Father, but by me. If you have known me, you would without doubt have known my Father also: and from henceforth you shall know him. And you have seen him" (DouayRheims The Holy Bible 109). Ricoeur specifies that God absents himself from the sinner as the "Wholly Other," while in this work, we maintain the accused conscience is the active agent that absents God as Salvation; for Ambrosio, it is possible that this absentia also includes Christ as the key to salvation.

It is also important to note the role of the Church in salvation and Ambrosio's absentia of it as well-a particularly puzzling aspect of the monk's consciousness of salvation (or lack thereof). Throughout The Monk we are constantly reminded through Lewis's narrator of Ambrosio's fame as the most holy of his order; however, we never see him engage in the act of the Eucharist even though we are told he was baptized early into the order of monks. We are aware that as his sins progress, he participates less in 
Matins, one of the canonical hours. Special church times and ceremonies such as Matins and the Eucharist are necessary for helping man in the spiritual life, Aquinas writes: "Consequently, just as for the spiritual life there had to be Baptism, which is spiritual generation; and Confirmation, which is spiritual growth: so there needed to be the sacrament of Eucharist, which is spiritual food. . . Consequently, the reception of Baptism is necessary for starting the spiritual life, while the receiving of the Eucharist is requisite for its consummation; by partaking not indeed actually, but in desire, as an end is possessed in desire and intention ("Question 73" par 5, 21). Thus, the Church, as the ultimate symbol of the body of Christ, is the physical mediator of salvation, while Christ is the spiritual one. We see Ambrosio begin to absent his consciousness from this "spiritual food" as the accused conscience, or the conscience that feels guilt, after he has fallen victim to the pleasures of the flesh and focused intentionality upon the physical world as opposed to the spiritual one:

Guilt was new to him, and He fancied that every eye could read the transactions of the night upon his countenance. He strove to pray; His bosom no longer glowed with devotion; His thoughts insensibly wandered to Matilda's secret charms. But what He wanted in purity of heart, He supplied by exterior sanctity. The better to cloak his transgression, He redoubled his pretensions to the semblance of virtue, and never appeared more devoted to Heaven as since He had broken through his engagements. Thus did He unconsciously add Hypocrisy to perjury and incontinence; He had fallen into the latter errors from yielding to seduction almost irresistible; But he was now guilty of a voluntary fault by endeavouring to conceal those, into which Another had betrayed him. (Lewis 226)

Here we note that Ambrosio feels guilt, and thus has internalized his sin, according to Ricoeur. Thus, it is possible he abstains from ceremonies such as the Eucharist because he knows his guilt, even though he continues to act in bad faith: "For he that eateth and drinketh unworthily eateth and drinketh judgment to himself, not discerning the body of the Lord," St. Paul writes (Douay-Rheims The Holy Bible 1 
Corinthians 11:29). In essence, as Ambrosio continues to exist as the "accused conscience" living in bad faith, he dooms himself to perdition because he deprives himself of essential instruments of salvation. Once Ambrosio's self embraces the idea that salvation is not possible, God and Christ mutate from the "Wholly Other," whose reclamation is possible and necessary for salvation, to the "Mythological Other," a being that exists only in the imagination with no possibility of reconciliation, and punishment through self-damnation ensues. Without faith as a mental bridge between God, Christ, and himself, and through his self's active removal of God and Christ as Salvation in his consciousness, Ambrosio's fate is inescapable. Next, we move to Ricoeur's idea of the "servile will," which is essential to our examination of Ambrosio's movement from the "accused conscience" to the "condemned" and eventually "damned conscience."

The Concept of the "Servile Will" in The Monk

Guilt cannot, in fact, express itself except in the indirect language of "captivity" and "infection," inherited from the two prior stages. Thus both symbols are transposed "inward" to express a freedom that enslaves itself, affects itself, and infects itself by its own choice. (Ricoeur, The Symbolism of Evil 152)

Ricoeur's idea of the "accused and condemned" conscience is one strongly associated with his concept of the "servile will," which is, essentially, a captive, free will. The apparent contradiction in terms illustrates the absurdity into which the sinner is thrust. Humankind's free will is enslaved because it is trapped in the experience/sin punishment/salvation dichotomies. Also, the concept of the servile will demonstrates the "will" as an active agent, as Ricoeur writes:

The Babylonian suppliant "confesses" and "repents"; he knows obscurely that his bonds are in some way his own work; if not, why should he cry: "undo the many sins that I have committed since my youth. I will fear the god; I will not 
commit offenses"? Why should the suppliant beg to be released from what he has committed if he did not know obscurely, if he did not know without knowing, if he did not know enigmatically and symbolically, that he has put upon himself the bonds from which he begs to be released? (153)

For Ricoeur, there are three aspects of the servile will: positiveness, externality, and infection. Positiveness refers to the idea that evil is not simply nothing, as many philosophers have postulated across the ages. Instead, it is the power of darkness and is something that can be "taken away" as God cleanses the sins of the world (155). If evil is reduced to simply nothing or a lack of goodness, it would exist outside the realm of defilement for Ricoeur. The second schema of the servile will, externality, refers to the idea that although guilt is experienced internally, it is only reflected in the symbol of its externality. Evil is experienced as something on the "outside" that corrupts or seduces the self on the "inside" (155). Ricoeur writes, "This externality is so essential to human evil that man, Kant says, cannot be absolutely wicked, cannot be the Evil One; his wickedness is always secondary; he is wicked through seduction" (155). Ricoeur's third schema of the servile will, infection, is the ultimate symbol of the servile will because it encompasses the "bad choice that binds itself" (155). The seduction from the outside, specified in the schema of externality, is an affection of the self by the self, according to Ricoeur, and it is this idea that is central to our understanding of Ambrosio's selfdamnation.

For Ricoeur, "Hell" begins the "accused and condemned conscience." The guilty conscience is one that is shut in because it is isolated: it breaks the communion of sinners. It separates itself as it takes the whole weight of evil upon itself (146). It is a slave and is conscious of its own enslavement; it is a conscience without "promise" in what Kierkegaard terms "despair" (146). It becomes "a despairing and desperate will to shut 
oneself up in the circle of interdiction and desire. We see this and Ricoeur's concept of the "servile will" evidenced at the end of Mathew Lewis's The Monk (1796), when Ambrosio is awaiting his fate at the hands of the Inquisition after his rape and murder of Antonia and the murder of Antonia's mother:

While Reason forced him to acknowledge a God's existence, Conscience made him doubt the infinity of his goodness. He disbelieved, that a Sinner like him could find mercy. He had not been deceived into error: Ignorance could furnish him with no excuse. He had seen vice in her true colours; Before He committed his crimes, He had computed every scruple of their weight; and yet he had committed them. "Pardon?" He would cry in an access of Phrenzy; "Oh! There can be none for me!" Persuaded of this, instead of humbling himself in penitence, of deploring his guilt, and employing his few remaining hours in deprecating Heaven's wrath, He abandoned himself to the transports of desperate rage; He sorrowed for the punishments of his crimes, not their commission; and exhaled his bosom's anguish in idle sighs, in vain lamentations, in blasphemy and despair. (426)

Certainly Ambrosio is the epitome of the "accused and condemned conscience" and the "servile will"; for our purposes, however, we will separate Ricoeur's idea of the "accused and condemned conscience" into the "accused conscience" experienced through guilt, the "condemned conscience," or the conscience struggling to retain its notion of salvation in the presence of unrestrained evil, and the "damned conscience," or the conscience that has, in effect, condemned itself to damnation.

Ambrosio's Movement from the "Accused Conscience" to the "Condemned" and "Damned" Consciences in The Monk

While it has proven difficult to determine a specific point where Ambrosio's consciousness progresses to the next point on his phenomenological path to damnation in this work, the movement from the "accused conscience" to the "condemned" and "damned" consciences is more concrete and marked by specific movements in Lewis's 
text. As examined above, Ambrosio's "despair"- a mortal sin-bars the way for his salvation; those who suffer from despair often indulge freely in other sins, as does Ambrosio. Lewis's narrator tells us Ambrosio sees "no other means to escape destruction" than to sign the contract Satan presents to him; because he has abandoned all hope of salvation, Ambrosio suffers from despair before he even signs the contract. Ambrosio's despair marks the movement from the "accused conscience" to the "damned conscience" because despair prevents salvation. However, this movement is also delineated by Ambrosio's realization and cessation of existing in Sartre's idea of bad faith; it is only through the self's realization that the picture the conscience has portrayed is a true one that the self can condemn itself and give itself over completely to Kierkegaard's idea of despair, as we see evidenced when we first encounter Ambrosio's thoughts while he awaits his fate at the hands of the Inquisition:

He waited with agony for the day of examination: He had no resource to comfort him in his distress. Religion could not inspire him with fortitude: If $\mathrm{He}$ read the Books of morality which were put into his hands, He saw in them nothing but the enormity of his offences; If he attempted to pray, He recollected that $\mathrm{He}$ deserved not heaven's protection, and believed his crimes so monstrous, as to baffle even God's infinite goodness. For every other Sinner, He thought there might be hope, but for him there could be none. Shuddering at the past, anguished by the present, and dreading the future, thus passed He the few days preceding that which was marked for his Trial. (Lewis 422)

Note here that although Ambrosio believes there is no salvation for him at this point, the concept of salvation is still very much alive in his consciousness. In addition, we see him moving between the dichotomy of damnation, as noted above, and salvation: "I will not sell my soul to perdition," he tells Matilda (430), while a few pages earlier he abandons himself to the "transports of desperate rage; He sorrowed for the punishment of his crimes, not their commission; and exhaled his bosom's anguish in idle sighs, in vain 
lamentations, in blasphemy and despair" (426). This marks the "condemned conscience," or a conscience in complete turmoil, caught in the dichotomy of damnation/salvation and the uncertainty that accompanies it. The condemned conscience has the ability to embrace the idea of salvation, even for itself, until its intersubjective constitution with others catapults it toward the "damned conscience," or the conscience that thrusts aside forever the notion of salvation. We see the primary instrument of Ambrosio's false intersubjective constitution-the shaping and defining of his self with the characters, events, and settings around him-Matilda, as an active agent in Ambrosio's progress from the "condemned" to the "damned" conscience. As Ambrosio suffers mentally and physically in his cell, Matilda appears to tell him how she has relinquished her hold on salvation forever. As the quintessential "damned conscience," Matilda describes her fate in glorious colors:

Yet I purchase my liberty at a dear, at a dreadful price! Dare you pay the same, Ambrosio? Dare you spring with fear over the bounds, which separate Men from Angels? - You are silent. - You look upon me with eyes of suspicion and alarm-I read your thoughts and confess their justice. Yes, Ambrosio; I have sacrificed all for life and liberty. I am no longer a candidate for heaven! I have renounced God's service, and am enlisted beneath the banners of his Foes. The deed is past recall: Yet were it in my power to go back, I would not. Oh! my Friend, to expire in such torments! To die amidst curses and execrations! To bear the insults of an exasperated Mob! To be exposed to all the mortifications of shame and infamy! Who can reflect without horror on such a doom? Let me then exult in my exchange. I have sold distant and uncertain happiness for present and secure: I have preserved a life, which otherwise I had lost in torture; and I have obtained the power of procuring every bliss, which can make that life delicious! The Infernal Spirits obey me as their Sovereign: By their aid shall my days be past in every refinement of luxury and voluptuousness. I will enjoy unrestrained the gratification of my senses: Every passion shall be indulged, even to satiety; Then will I bid my Servants invent new pleasures, to revive and stimulate my glutted appetites! ... Summon then your resolution to your aid; and renounce for immediate and certain benefits the hopes of a salvation, difficult to obtain, and perhaps altogether erroneous. Shake off the prejudice of vulgar souls; Abandon a God, who has abandoned you, and raise yourself to the level of superior beings! (428-9) 
Matilda portrays perhaps the primary aspect of the "condemned conscience"-a total encompassing surrender of spiritual salvation for physical pleasure, or intentionality focused completely upon the physical world as opposed to the spiritual one. Note here that we have expanded upon Ricoeur's notion of the "accused and condemned conscience" to add intentionality directed to the physical lifeworld, or the world as experienced by the senses. Ambrosio, however, continues to exist as the condemned conscience because he illustrates the entrapment between the damnation/salvation dichotomy when he replies, "Wretched Woman, what have you done? Pass but a few years, and how dreadful will be your sufferings!" (429) This comment, however, identifies Ambrosio's blurring of the physical and the spiritual as he anticipates horrific physical suffering in a spiritual realm. This is re-edified when Ambrosio witnesses the true appearance of Satan, the ultimate symbol of damnation, as we shall discuss later in this section of this work.

For the "damned conscience," one we add to Ricoeur's ideas in The Symbolism of Evil, there is no hope of spiritual salvation, and all behavior indicative of a good moral conscience disappears. This is the reconvening of the self and conscience because at this point, the conscience ceases as an active agent holding a mirror for the self; the self, in effect, is doomed, an instrument of its own damnation. In addition, the dichotomy of damnation/salvation shifts to the idea of damnation/punishment. Ambrosio's movement from the condemned conscience to the damned conscience is not accomplished without reservation; the first time he summons Satan to his aid, he refuses to sign the contract relegating his soul to the demon. In addition, the second time Ambrosio summons Satan, he hesitates before signing the instrument. "In effect, the Archers were heard 
approaching, appointed to lead Ambrosio to the Stake. The sound encouraged the Monk to his resolution," Lewis's narrator tells us, highlighting Ambrosio's intention of the physical world as opposed to the spiritual one. Ambrosio, "worked up to a phrenzy by the urgent danger, shrinking from the approach of death, terrified by the Daemon's threats, and seeing no other means to escape destruction," signs the contract Satan has presented. Afterward, Satan reveals Ambrosio's crimes to him in all their glory, including the rape and murder of his sister, Antonia, and the murder of his mother, Elvira. Satan also reveals himself as a primary instrument in the monk's false intersubjective constitution: Matilda is a demon Satan sent to deliberately tempt Ambrosio. The demon continues:

And you it was who thought yourself proof against temptation, absolved from human frailties, and free from error and vice! Is pride then a virtue? Is inhumanity no fault? Know, vain Man! That I long have marked you for my prey: I watched the movements of your heart; I saw that you were virtuous from vanity, not principle, and I seized the fit moment of seduction. . . . Hear, hear, Ambrosio! Had you resisted me one minute longer, you had saved your body and soul. The guards whom you heard at your prison-door, came to signify your pardon. But I had already triumphed: My plots had already succeeded. Scarcely could I propose crimes so quick as you performed them. You are mine, and Heaven itself cannot rescue you from my power. Hope not that your penitence will make void our contract. Here is your bond signed with your blood; You have given up your claim to mercy, and nothing can restore to you the rights which you have foolishly resigned. (440)

After this, Ambrosio sinks to his knees and raises his hands to heaven. While this could be viewed as an act of contrition establishing the idea of salvation in Ambrosio's consciousness indicating he is still at the "condemned conscience" stage, there is nothing in Lewis's text to validate this as anything other than a last, desperate measure the monk realizes is useless.

At this point, the culmination of the ideal-type religious consciousness and the damned conscience lead the monk directly into the concept of punishment, which carries 
a wealth of scriptural and philosophical components and is integral to the idea of the damned conscience. To be damned is not only to relinquish claims to salvation, but to self-suffer for relinquishing the Grace of God. According to Aquinas, such punishment is indirect in that it is not directly administered by God, but God allows us to give ourselves over to sin; "It is in this sense that the Apostle speaks (Romans 1:24) when he says, 'Wherefore God gave them up to the desires of their heart,' i.e. to their passions; because, to wit, when men are deprived of the help of Divine grace, they are overcome by their passions," he writes ("Question 87. The debt of punishment" par 6). Divine Grace is withdrawn because of sin (par 15). A sin incurs a debt of eternal punishment if it "destroys the principle of the order whereby man's will is subject to God" and is thus "such as to be considered in itself irreparable," although God, of course, can repair any sin (par 23). "It is just that he who has sinned against God in his own eternity should be punished in God's eternity. A man is said to have sinned in his own eternity, not only as regards continual sinning throughout his whole life, but also because, from the very fact that he fixes his end in sin, he has the will to sin, everlastingly," Aquinas writes (par 24). For his transgressions, Ambrosio sentences himself to physical and spiritual punishment. Satan throws him from a steep precipice, and he lies at the bottom of the mountain, dying a slow, agonizing death. His physical behavior, symbolic of his physical and spiritual damnation, regresses to that of a demon, as, "Blind, maimed, helpless, and despairing, venting his rage in blasphemy and curses, execrating his existence, yet dreading the arrival of death destined to yield him up to greater torments, six miserable days did the Villain languish" (442). A violent storm arises on the seventh day, and the torrent of rain washes the "Corse of the despairing Monk" into the river. 


\section{Conclusion: The Consciousness of Damnation}

He had not been deceived into error: Ignorance could furnish him with no excuse. He had seen vice in her true colours; Before He committed his crimes, He had computed every scruple of their weight; and yet he had committed them.

'Pardon?' He would cry in an access of phrenzy 'Oh! there can be none for me!' (Lewis 426)

Throughout this work, we have traversed Ambrosio's phenomenological path to damnation, tracing his movement from the "unhappy conscience" through the "accused" and "condemned" consciences to the "damned conscience" primarily responsible for his self-damnation. We have examined his false intersubjective constitution with the religious symbols surrounding him in the text, including Matilda, Satan, and physical artifacts such as the abbey garden as the anti-Eden and the monastery as the polluted religious space. Sartre's "bad faith" permeates Ambrosio's self as it resists the truth his conscience, an active agent, strives to present to him. These, coupled with the death of his faith-the primary way we "know" God and seek him, as opposed to Ricoeur's idea that God absents himself — pushes Ambrosio, a victim of Ricoeur's idea of the "servile will," to his self-damnation. At the end of Lewis's text, Ambrosio has truly relinquished all hope of salvation from the Creator, which further validates Matilda's and Satan's epithets of the monk's impending spiritual doom.

Could the monk have saved himself? Scripture and religious philosophy certainly emphasize God's never-ending forgiveness. Ephesians 1:7 states, "In whom we have redemption through his blood, the remission of sins, according to the riches of his grace," (Douay-Rheims The Holy Bible 195) and Romans 6: 12 affirms:

But the justice which is of faith, speaketh thus: Say not in thy heart, Who shall ascend into heaven? that is, to bring Christ down; Or who shall descend into the deep? that is, to bring up Christ again from the dead. But what saith the scripture? The word is nigh thee, even in thy mouth, and in thy heart. This is the 
word of faith, which we preach. For if thou confess with thy mouth the Lord Jesus, and believe in thy heart that God hath raised him up from the dead, thou shalt be saved. For, with the heart, we believe unto justice; but, with the mouth, confession is made unto salvation. For the scripture saith: Whosoever believeth in him, shall not be confounded. For there is no distinction of the Jew and the Greek: for the same is Lord over all, rich unto all that call upon him. For whosoever shall call upon the name of the Lord, shall be saved. (156)

In addition, Aquinas writes "that God alone is the principal efficient cause of the forgiveness of sin" (Summa 410). At any time the despairing monk could have attained the forgiveness of God, even as Satan indicates at the end of Lewis's text, after Ambrosio has signed the fateful document: "Had you resisted me one minute longer, you had saved your body and soul. The guards whom you heard at your prison-door, came to signify your pardon," the demon cries (440). However, as scripture dictates, without seeking redemption, salvation is not possible, and at this point in Ambrosio's consciousness, salvation had reached nonexistence. Because of his dead faith in salvation offered through Christ and the grace of God, Ambrosio's self, now merged with the "damned conscience," posits God as the "Mythical Other" in his consciousness, in effect sealing his physical and spiritual doom in an eternity of torment, disgrace, and despair. 


\section{Endnotes}

1 Note that, as mentioned in other chapters of this work, Ambrosio also blames others for his own faults and actions, in effect continuing his existence in Sartre's idea of bad faith. As Sartre writes in Existentialism and Humanism: "If existence really precedes essence, man is responsible for what he is. Thus, the first step of existentialism is to show every man to be in control of what he is and to make him assume total responsibility for his existence." (207)

2 The "nature vs. nurture" debate was heated in England in the late 1700s, as evidenced in some of the literature of the period. Percy Shelley wrote in his preview of Frankenstein, "Treat a person ill, and he will become wicked" (Smith 190). In Mary Shelley's Frankenstein, the creature notes that his behavior is because of his reception (or lack thereof) in society. Percy and Mary Shelley's ideas are grounded in the work of Mary Shelley's father, William Godwin, author of An Enquiry Concerning Political Justice (1793) and his 1794 novel, Things as They Are, or The Adventures of Caleb Williams, in which Caleb describes how injustice and betrayal turn him into "a deserted, solitary, wretch" (Godwin 193). 


\section{REFERENCES}

A Brief History of Sin. 26 Jan. 2008. <http://www.deadlysins.com/sins/history.html>. Alighieri, Dante. The Divine Comedy. Trans. John Ciardi. New York: New American Library, 1970.

An Aquinas Reader. Ed. Mary T. Clark. New York: Fordham University Press, 2000. Anselm of Canterbury. "On Free Will." The Major Works. Ed. Brian Davies and G. R. Evans. Oxford: Oxford University Press, 1998.

Anselm of Canterbury. "On the Virgin Conception and Original Sin." The Major Works.

Eds. Brian Davies and G. R. Evans. Oxford: Oxford University Press, 1998.

Anselm of Canterbury. The Major Works. Eds. Brian Davies and G. R. Evans. New York: Oxford University Press Inc., 1998.

Aquinas, Thomas. "Question 5: The effect of contrition." Summa Theologica. 7 Oct. $2008<$ http://www.newadvent.org/summa/5005.htm>.

Aquinas, Thomas. "Question 26: Christ as called the mediator of God and man." Summa Theologica. 7 Oct. $2008<$ http://www.newadvent.org/summa/4026.htm>.

Aquinas, St. Thomas. "Question 52: Christ's Descent Into Hell.” Summa Theologica. 24 Sept. $2008<$ http://www.newadvent.org/summa/4052.htm>.

Aquinas, Thomas. "Question 73: The sacrament of the Eucharist." Summa Theologica. 7 Oct. $2008<$ http://www.newadvent.org/summa/4073.htm>.

Aquinas, Thomas. "Question 87: The debt of punishment." Summa Theologica. 7 Oct. $2008<$ http://www.newadvent.org/summa/4087htm>. 
Aquinas, Thomas. "Question 118: The Vices Opposed to Liberality, and in the First Place, Covetousness." Summa Theologica. 18 Feb. 2008. $<$ http://www.newadvent.org/summa/3118.htm>.

Aquinas, Thomas. "Question 148: Gluttony." Summa Theologica. 19 Feb. 2008. $<$ http://www.newadvent.org/summa/3148.htm>.

Aquinas, Thomas. "Question 153: Lust." Summa Theologica. 19 Feb. 2008. $<$ http://www.newadvent.org/summa/3153.htm>.

Aquinas, Thomas. "Question 154: The Parts of Lust.” Summa Theologica. 18 Feb. 2008. $<$ http://www.newadvent.org/summa/3154.htm>.

Aquinas, Thomas. "Question 158: Anger.” Summa Theologica. 19 Feb. 2008. $<$ http://www.newadvent.org/summa/3158.htm>.

Aquinas, Thomas. "Question 162: Pride.” Summa Theologica. 19 Feb. 2008. $<$ http://www.newadvent.org/summa/3162.htm>.

Aquinas, St. Thomas. Selection from "Summa contra gentiles." Witchcraft in Europe 400-1700: A Documentary History. Eds. Alan Charles Kors and Edward Peters. Philadelphia: University of Pennsylvania Press, 2001.

Aquinas, St. Thomas. Selection from "Summa theologica." Witchcraft in Europe 4001700: A Documentary History. Eds. Alan Charles Kors and Edward Peters. Philadelphia: University of Pennsylvania Press, 2001.

Aquinas, Thomas. Summa Theologica. Volume II. Chicago: Encyclopedia Britannica, Inc., 1952.

Augustine. On Free Choice of the Will. Trans. Thomas Williams. Indianapolis: Hackett Publishing Company, 1993. 
Augustine. Selections from "De Dectrina Christiana." Witchcraft in Europe 400-1700: A Documentary History. Eds. Alan Charles Kors and Edward Peters. Philadelphia: University of Pennsylvania Press, 2001.

Barrell, John. Imagining the King's Death: Figurative Treason, Fantasies of Regicide 1793-1796. Oxford: Oxford University Press, 2000.

Bultmann, Rudolf. New Testament \& Mythology and Other Basic Writings. Ed. Schubert M. Ogden. Philadelphia: Fortress Press, 1984.

Burke, Edmond. Selections from Reflections on the Revolution in France. British Literature 1780-1830. Eds. Anne K. Mellor and Richard E. Matlak. Fort Worth: Harcourt Brace College Publishers, 1996.

Caesarius of Arles. "An Admonition to Those Who Not Only Pay Attention to Omens, but, What is Worse, Consult Seers, Soothsayers, and Fortune-Tellers in the Manner of Pagans." Witchcraft in Europe 400-1700: A Documentary History. Eds. Alan Charles Kors and Edward Peters. Philadelphia: University of Pennsylvania Press, 2001.

Campbell, Ann. "Satire in The Monk: Exposure and Reformation." Romanticism On the Net 8 (November 1997) 31 Jan. 2007 $<$ http://users.ox.ac.uk/ scat0385/satire.html>.

"Cathedral of St. Cecelia, Albi." Sacred Destinations: An Illustrated Guide to Sacred Sites, Pilgrimmages, Religious Art, and Historic Holy Places Around the World. 2 Nov. 2008. <http://www.sacred-destinations.com/france/albi-cathedral-stececile.htm> .

Catholic Encyclopedia. Despair. <http://www.newadvent.org/cathen/04755a.htm>. 
Coleridge, Samuel Taylor. Reprint of "The Monk. A Romance. By M. G. Lewis, Esq. M.P. 3 Vols. Bell. 1796.” 28 Aug. 2007 $<$ http://www.english.upenn.edu/ mgamer/Etexts/coleridge.reviews>.

Coleridge, Samuel Taylor. "The Rime of the Ancient Mariner." The Rime of the Ancient Mariner and Other Poems of the Romantic Era. Clayton, Delaware: Prestwick House Literary Touchstone Classics, 2006.

Dacre, Charlotte. Zofloya Or The Moor. Oxford: Oxford University Press, 1997. Detweiler, Robert. Story, Sign, and Self: Phenomenology and Structuralism as LiteraryCritical Methods. Philadelphia: Fortress Press, 1978.

Dilthey, Wilhelm. "Construction of the Historical World." Dilthey's Epistemology and Methodology. Handout for PHIL 605, Hermeneutics. University of Louisville, Fall 2004.

Douay-Rheims The Holy Bible. Fitzwilliam, NH: Loreto Publications, 2005.

Duffner, Father Paul A., O.P. "The Vice of Sloth.” The Rosary Light and Life. Vol. 52, No. 2, March-April 1999, online <http://www.rosary-center.org/l152n2.htm> .

Elwell, Frank. The Sociology of Max Weber. 12 Nov. 2007. <http://www.faculty.rsu.edu/ felwell/Theorists/Weber/Whome.htm >.

Gadamer, Hans-Georg. Truth and Method. Trans. Joel Weinsheimer and Donald G. Marshall. New York: Contiuum, 2003.

Godwin, William. Excerpt from Things as They Are, or The Adventures of Caleb Williams. Frankenstein. Ed. Joanna M. Smith. Boston: Bedford/St. Martin's, 2000.

Hawthorne, Nathaniel. "The Man of Adamant." American Gothic Tales. Ed. Joyce Carol 
Oates. New York: Plume, 1996.

Herbert F. Johnson Museum of Art. Handbook: The Sleep of Reason Produces Monsters. 20 Sept. $2008<$ http://www.museum.cornell.edu/HFJ/handbook/hb128.html>.

Hogle, Jerrold, ed. The Cambridge Companion to Gothic Fiction. Cambridge: Cambridge University Press, 2002.

Hogle, Jerrold. "The Ghost of the Counterfeit-and the Closet-in The Monk."

Romanticism On the Net 8 (November 1997)

$<$ http://users.ox.ac.uk/ scat0385/ghost.html>.

Husserl, Edmund. Cartesian Meditations: An Introduction to Phenomenology. Trans.

Dorion Cairns. Boston: Kluwer Academic Publishers, 1999.

Idhe, Don. "Hermeneutic Phenomenology: The Symbolism of Evil." Hermeneutic

Phenomenology: The Philosophy of Paul Ricoeur. Evanston: Northwestern University Press, 1971.

Kastenbaum, Robert. Seven Deadly Sins: Historical Perspective, Influence of the Seven

Deadly Sins. 28 Jan. 2008. <http://www.deathreference.com/Py-Se/Seven-

Deadly-Sins.html>.

Kierkegaard, Soren. "The Universality of This Sickness." Excerpt from The Sickness

Unto Death. Trans. Howard V. Hong and Edna H. Hong. The Bedford Anthology

of World Literature: The Nineteenth Century, 1800-1900. Boston: Bedford/St.

Martin's, 2003.

Kramer, Heinrich and Jacob Sprenger. “The Malleus Maleficarum.” Witchcraft in Europe 400-1700: A Documentary History. Eds. Alan Charles Kors and

Edward Peters. Philadelphia: University of Pennsylvania Press, 2001. 
Lewis, Matthew. The Monk. Oxford: Oxford University Press, 1998.

McCalman, Ian, John Mee, Gillian Russell, Clara Tuite, and Kate Fullagar. An Oxford Companion to the Romantic Age. Oxford: Oxford University Press, 2001.

Medieval Painting of the Seven Deadly Sins. 13 April 2008.

<http://www.paintedchurch.org/lthor7ds.htm>.

Milton, John. Paradise Lost. New York: W.W. Norton \& Company, 1975.

Moore, Brook and Kenneth Bruder. Philosophy: The Power of Ideas. Boston: McGraw Hill, 2005.

Paley, Morton D. William Blake. Oxford: Phaidon Press Limited, 1978.

Peck, Louis F. A Life of Matthew G. Lewis. Cambridge: Harvard University Press, 1961.

Poe, Edgar Allen. "Ligeia." Selected Writings. Ed. David Galloway. New York: Penguin Books, 1981.

Poe, Edgar Allen. "The Black Cat." Selected Writings. Ed. David Galloway. New York: Penguin Books, 1981.

Princeton University Library Digital Collections. "Gillray Collection.” 26 Oct. 2006. $<$ http://diglib.princeton.edu/xquery?_xq=getCollection\&_xsl=collection\&_pid=gc $108>$.

Ricoeur, Paul. "Existence and Hermeneutics." The Conflict of Interpretations. Evanston: Northwestern University Press, 1974.

Ricoeur, Paul. "The Task of Hermeneutics." Handout for PHIL 605, Hermeneutics. University of Louisville, Fall 2004.

Ricoeur, Paul. "Foreword." Hermeneutic Phenomenology: The Philosophy of Paul Ricoeur. Evanston: Northwestern University Press, 1971. 
Ricoeur, Paul. The Symbolism of Evil. Boston: Beacon Press, 1967.

Russell, Bertrand. A History of Western Philosophy. New York: Simon \& Schuster, 1945.

Sartre, Jean Paul. Excerpt from Existentialism and Humanism. Philosophy: The Power of Ideas. Eds. Brooke Noel Moore and Kenneth Bruder. Boston: McGraw Hill, 2008.

Schopenhauer, Authur. Selection from The Will As Representation. Philosophy: The Power of Ideas. Eds. Brooke Noel Moore and Kenneth Bruder. Boston: McGraw Hill, 2005.

Schimmel, Solomon. The Seven Deadly Sins: Jewish, Christian, and Classical Reflections on Human Nature. New York: The Free Press, 1992.

Shelley, Mary. Frankenstein. New York: Dover Publications Inc., 1994.

"Sin." Catholic Encyclopedia. 18 Feb. 2008.

$<$ http://www.newadvent.org/cathen/14004b.htm>.

Smith, Joanna. "Contextual Documents: Editor's Note." Frankenstein. Boston: Bedford/St. Martin's, 2000.

"St. Rosalia." Catholic Online. 18 Jan. 2008.

$<$ http://www.catholic.org/saints/saint.php?saint_id=157>.

Stephenson, Robert Louis. Strange Case of Dr. Jekyll and Mr. Hyde. New York: Dover Thrift Editions, 1991.

Stoker, Bram. Dracula. Oxford: Oxford World's Classics, 1998.

Student Bible. Notes by Philip Yancey and Tim Stafford. New International

Version. Grand Rapids: Zondervan Corporation, 2002.

Swanson, R.N. Religion and Devotion in Europe c. 1215-1515. Cambridge: Cambridge 
University Press, 1995.

Tienhooven, Marie Jose. "All Roads Lead to England: The Monk Constructs the Nation."

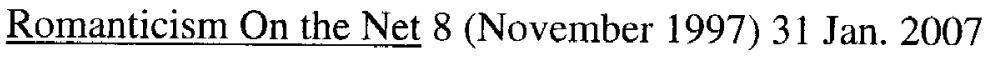
<http://users.ox.ac.uk/ scat0385/nation.html>.

Tomoroy, Peter. "Plate XIV." The Life and Art of Henry Fuseli. New York: Praeger Publishers, 1972.

Tomoroy, Peter. The Life and Art of Henry Fuseli. New York: Praeger Publishers, 1972. Tuite, Clara. "Cloistered Closets: Enlightenment Pornography, The Confessional State, Homosexual Persecution and The Monk." Romanticism On the Net 8 (November 1997) 31 Jan. 2007 <http://users.ox.ac.uk/ scat0385/closet.html >.

University of Leicester. Seven Deadly Sins FAQ. 20 Dec. 2001. 26 Jan. 2008. <http://www.le.ac.uk/arthistory/seedcorn/faq-sds.html>.

Varenne, Herve. "The Methodology of the Social Sciences." 15 Nov. 2007. < http://varenne.tc.columbia.edu/bib/info/webr0max049methsoci.html The methodology of the social sciences $>$.

Walpole, Horace. The Castle of Otranto. New York: Penguin Books, 2001.

Wells, H.G. The Island of Dr. Moreau. New York: Dover Publications, Inc., 1996.

Whitlark, James. "Heresy Hunting: The Monk and the French Revolution." Romanticism On the Net 8 (November 1997) 31 Jan. 2007 <http://users.ox.ac.uk/ scat0385/heresy.html>.

Witchcraft in Europe 400-1700: A Documentary History. Eds. Alan Charles Kors and Edward Peters. Philadelphia: University of Pennsylvania Press, 2001. 


\title{
CURRICULUM VITAE
}

\author{
Becky Lee Meadows \\ 132 Briarwood Court \\ Carrollton, KY 41008 \\ (502) 741-6916
}

\section{ACADEMIC EXPERIENCE:}

University of Louisville, Louisville, Ky.

August 2008-present

Part-time lecturer for the Humanities Department. Teaching HUM 152, Cultures of

America, for the Fall 2008 semester.

McKendree University, Louisville, Ky.

February 2008-present

Part-time lecturer for Philosophy, Humanities, and English courses. Teaching PHI 201, Introduction to Philosophy, a hybrid course using the Blackboard course delivery system, for September 2008.

South University Online, Savannah, Ga.

January 2008-present Facilitator for English and Effective Public Speaking online using the eCollege learning platform. Responsible for assisting students with eCollege and seeing their successful completion of the courses.

Indiana University Southeast, Sellersburg, Ind.

August 2007-present

On the institution's roster as a part-time lecturer for English Composition courses with an interdisciplinary focus. Students explore philosophy, literature, art, and film as bases for writing compositions. Used IUS's own online learning platform for the hybrid course.

Bellarmine University, Louisville, Ky.

August 2007-present On the institution's roster as a part-time lecturer for English Composition courses with an interdisciplinary focus; use the Blackboard online learning platform for the hybrid courses. Students explore philosophy, literature, art, and film as bases for writing compositions.

DeVry University, Louisville, Ky.

July 2008-present Adjunct instructor of English and Humanities. Students explore various disciplines in the Humanities in courses.

Brown Mackie College, Louisville, Ky.

Part-time lecturer for Effective Public Speaking, Business Communications, and English Composition. Used the eCollege online learning platform to teach hybrid courses.

Responsible for assisting students with eCollege and seeing their successful completion of the courses. 
University of Louisville/Quality Leadership Academy,

Panama City, Panama

August 5-18, 2007

Represented the university internationally by teaching HUM 152, Cultures of America, at the Quality Leadership University in Panama City, Panama, for a 4-week course.

Ivy Tech Community College of Indiana, Madison, Ind. 2007

Assistant Professor and Program Chairperson for Liberal Arts. Responsible for promoting program, including student recruitment and retention; planning, scheduling, and development of Liberal Arts Program courses; and hiring full-time and adjunct faculty. Also responsible for implementing hybrid and online courses into the Liberal Arts Program. Participated in a statewide panel to develop a single ENG 111 online course for all 23 campuses to use using the Blackboard online learning platform. Courses taught: PHL 101 (Introduction to Philosophy); PHL 102 (Ethics); HUM 201 (Introduction to Humanities I); HUM 202 (Introduction to Humanities II); ENG 111 (Composition).

University of Louisville, Louisville, Ky.

August 2003-December 2005

Graduate Teaching Assistant as part of university's PhD in Humanities program. Professor of Humanities, English, and Theatre courses beginning with Fall 2003 semester. Made most courses hybrid, using the Blackboard online learning platform. Courses taught: HUM 376 (The American Gothic), HUM 376 (Fantasy Fiction and Film); TA 324 (Acting for Non-Majors), ENG 101 (Freshman Composition), HUM 152 (Cultures of America), HUM 102 (Western Literature 1700-present).

Jefferson Community College, Louisville, Ky.

August 1999-June 2004

Adjunct professor of English, journalism, and theatre courses for the college located in downtown Louisville, Ky. Also served as adviser of the student newspaper, the Quadrangle, for five years. Classes taught: ENG 101 and 102 (Freshman Composition); ENG 090 and 091 (Developmental English courses); TA 120 (Acting I); ENG 101 (for gifted high school students).

Ivy Tech State College, Madison, Ind. January 2000 to August 2003 Adjunct professor of English and Communications. Courses taught: ENG 111 (Freshman Composition); CMS 110 (Interpersonal Communications); Developmental English courses.

\section{ACADEMIC CREDENTIALS:}

University of Louisville, Louisville, Ky.

August 2003-Dec. 2008

Doctor of Philosophy degree in Humanities, Studies in Culture designation. Areas of specialty are Philosophy (phenomenology and hermeneutics) and the Gothic (art and literature). Dissertation title: The Consciousness of Damnation: A HermeneuticalPhenomenology of the Fall of the Self in The Monk. GPA: 3.9.

University of Louisville, Louisville, Ky.

August 1997-May 2002

Master of Arts degree in English with emphasis in Creative Writing and Literature. Also earned more than 20 hours in graduate-level theatre arts courses. GPA: 3.6.

University of Missouri-Columbia, Columbia, Mo.

August 1988-May 1991

Bachelor of Journalism degree and minor in Political Science. GPA: 3.62. 


\section{PUBLICATIONS/PRESENTATIONS/AWARDS:}

- Dissertation, The Consciousness of Damnation: A Hermeneutical Phenomenology of the Fall of the Self in Matthew Lewis's The Monk, University of Louisville, December 2008.

- Teacher of the Term award for Fall I session (student-voted), DeVry University, November 2008.

- Group Leader representing English faculty at McKendree University annual employee meeting, August 2008, Ft. Knox, Ky.

- Guest lecturer for SOC 1001 course at Brown Mackie College, Louisville, Ky., June 2008. Presentation focused on the political theories and cultural events surrounding the lives of philosophers John Locke and Thomas Hobbes.

- Paper presentation, "The "Crisis of Spirit" and the Pinnacle of the Gothic Novel in England, 1790-1820; Or, What Happens When We Can't 'Know' What We Know?" for the Kentucky Philological Association meeting in Louisville, Ky., March 2008. Papers presented electronically because conference was canceled because of snow.

- Invited in November 2007 to be one of 35 scholars to present a paper and participate in the Oxford Round Table discussion of ethics and politics, to be held at Oxford University, England, August 5-10, 2007.

- Contracted by University of Louisville to teach HUM 152, Cultures of America, in Panama City, Panama, Aug. 6-17, 2007.

- Paper presentation, "'Fearful is Night to the Guilty': Living with the Horror of One's Evil Ways in The Monk," to the Kentucky Philological Association conference, March 2006. Paper named "Best of Section."

- Publication of abstract of "'Fearful is Night to the Guilty': Living with the Horror of One's Evil Ways in The Monk," in the Kentucky Philological Review, 2006.

- Publication of abstract, "Manic Depression, Childhood Bereavement, and the Return of the Dead in Edgar Allan Poe's Works," in Kentucky Philological Review, 2005.

- Paper presentation, "A Hermeneutics of the Aesthetic Experience," to the Popular Culture and American Culture Association conference, October 2005.

- Paper presentation, "'Fearful is Night to the Guilty": Living with the Horror of One's Evil Ways in The Monk," to the Popular Culture and American Culture Association conference, October 2005.

- Paper presentation, "Manic Depression, Childhood Bereavement, and the Return of the Dead in Edgar Allan Poe's Works," to the Kentucky Philological Association, March 2005. Paper named "Best of Section."

- Publication of abstract, "He's Here, He's Here, He's Here, But Where Is He? Academic Discourse and The Phantom of the Opera" in the Kentucky Philological Review, 2004. 
- Paper presentation, "Manic Depression, Childhood Bereavement, and the Return of the Dead in Edgar Allan Poe's Works," for the University of Louisville Humanities Colloquium, April 2005.

- Paper presentation, "He's Here, He's Here, He's Here, But Where Is He? Academic Discourse and The Phantom of the Opera," to the Kentucky Philological Association, March 2004. Paper named "Best of Section." Member of Kentucky Philological Association.

- Published author of two novels. The first, Progeny, was published in March 2001; the second, Phantasy, was published in May 2002. The third work in the trilogy is in the works.

\section{SPECIAL INTERESTS/PROFESSIONAL ORGANIZATIONS:}

- Wrote and secured grant for the Jefferson Community College student newspaper, the Quadrangle, and secured $\$ 10,000$ in scholarship funding from the Gannett Foundation.

- Wrote and secured grant funds from the Indiana Humanities Council to help fund the 2008 Southeast Indiana Humanities Conference.

- Wrote and secured $\$ 1,000$ internal Faculty Grant from Ivy Tech Community College of Indiana to fund first annual Southeast Indiana Humanities Conference at Indiana University Southeast, held March 2-3, 2007. Chairperson and founder of the conference.

- Former President of Ivy Tech Community College of Indiana/Madison Faculty Senate.

- Former Chairperson of Ivy Tech Community College of Indiana statewide Humanities Curriculum Committee.

- Member of American Association of University Professors; University of Louisville Humanities Undergraduate and Graduate Organization (HUGO); Kentucky Philological Association; American Philosophical Association; Society for Phenomenology and Existential Philosophy; Kentucky Philosophical Association; Indiana Philosophical Association; National Association of Humanities Educators; Midwestern American Society for Eighteenth Century Studies; Louisville Federation of Musicians; American Federation of Musicians.

- Member of Golden Key International Honour Society based on excellence in postgraduate studies; member of the group's "Graduate School CEO Think-Tank."

- Former public speaker listed with the University of Louisville Speakers Bureau. Have spoken to various organizations on topics, "Gender Roles in Country Music" and "You Make It Happen Yourself." Groups included high schools and various professional organizations.

- Musical theatre background. Have earned more than 20 graduate hours in theatre from the University of Louisville, and performed various roles in musicals including Eva Peron in Evita, Rizzo in Grease, and Lily in The Secret Garden for community theatres. 
REFERENCES:

Dr. Annette Allen

PhD in Humanities Program Director

University of Louisville Belknap Campus

Louisville, KY 40292

502-852-5555

Acalle01@louisville.edu

Dr. Glynis Ridley

Dissertation Director

University of Louisville Belknap Campus

Louisville, KY 40292

502-852-5555, Glynis.ridley@louisville.edu

Elaine Wise

Director, Humanities Department

University of Louisville

Louisville, Ky. 40292

(502) 852-5555, Eowise01@louisville.edu

Dr. Osborne Wiggins

Dissertation Committee Member

University of Louisville

Louisville, KY 40292

(502) 852-5555, Opwigg01@louisville.edu

Jane Berard

South University Online

Professor and Faculty Program Director

English Program

jberard@southuniversity.edu

Stacey Fitzpatrick

General Education Chairperson

Ivy Tech Community College of Indiana

590 Ivy Drive

Madison, IN 47250

812-569-5855, sfitzpat@ivytech.edu

Margaret Seifert

ELearning Director (online courses)

Ivy Tech Community College of Indiana

509 Ivy Tech Drive

Madison, IN 47250

(812) 265-2580, mseifert@ivytech.edu 